\author{
UNIVERSIDADE DE SÃO PAULO \\ FACULDADE DE FILOSOFIA, LETRAS E CIÊNCIAS HUMANAS \\ DEPARTAMENTO DE ANTROPOLOGIA \\ PROGRAMA DE PÓS-GRADUAÇÃO EM ANTROPOLOGIA SOCIAL
}

MOISÉS RAMALHO

\title{
Os Yanomami e a morte
}

São Paulo

2008 


\author{
UNIVERSIDADE DE SÃO PAULO \\ FACULDADE DE FILOSOFIA, LETRAS E CIÊNCIAS HUMANAS \\ DEPARTAMENTO DE ANTROPOLOGIA \\ PROGRAMA DE PÓS-GRADUAÇÃO EM ANTROPOLOGIA SOCIAL
}

\title{
Os Yanomami e a morte
}

Moisés Ramalho

Tese apresentada ao Programa de PósGraduação em Antropologia Social do Departamento de Antropologia da Faculdade de Filosofia, Letras e Ciências Humanas da Universidade de São Paulo, para a obtenção do título de doutor em Antropologia

Orientadora: Prof $^{\mathrm{a}}$. Dr ${ }^{\mathrm{a}}$. Beatriz Perrone-Moisés

São Paulo 


\section{Resumo}

Esta tese tem por objeto a relação dos Yanomami do norte amazônico com a morte, tomada como via privilegiada de aprofundamento de nosso entendimento de seus modos de ser/estar no universo, hutu kara, dizem eles. Descreve seus conceitos de comunidade, cuja existência e funcionamento estão intimamente ligados à máquina ritual-escatológica, delineia os pontos centrais de sua ontologia e de sua noção de pessoa e analisa o ritual mortuário, reahu, propondo ver nele a realização máxima dos mais vários aspectos da cosmologia e da vida social yanomami. Baseada em experiência de campo de uma década, incorpora a vasta literatura dedicada aos Yanomami à luz de fatos observados e, sobretudo, de explicações que me foram dadas por eles ao longo dos anos.

\section{Abstract}

This thesis is dedicated to the northern-amazonian Yanomami's relation to death, taken as a privileged way of deepening our understandings of their modes of being in the universe, hutu kara, as they say. It describes their concepts of community, whose existence and functioning are intimately related to the ritual-eschatological machine, outlines the main points of their ontology and notion of personhood and analises the mortuary ritual, reahu, proposing to see it as the ultimate realization of the various aspects of yanomami cosmology and social life. Based on fieldwork carried on for more than a decade, it incorporates the vast literature on the Yanomami in the light of observed facts and, above all, of the explanations given to me by them throughout the years.

\section{Résumé}

Cette thèse est consacrée au rapport entre les Yanomami du nord de l'Amazonie brésilienne et la mort, considérée comme une voie privilégiée pour l'approfondissement de nos entendements de leurs modes d'être dans l'univers, hutu kara, comme ils disent. On y décrit leurs concepts de communauté, dont l'existence et le fonctionnement sont étroitement liés à la machine rituelle-eschatologique, on y ébauche les points centraux de leur ontologie et de leur notion de personne et on analise le rituel mortuaire, reahu, en proposant d'y voir la réalisation ultime de plusieurs apspects de la cosmologie et de la vie sociale yanomami. Basée sur une expérience sur le terrain au cours de plus d'une décennie, elle incorpore la vaste littérature sur les Yanomami à la lumière de faits observés et, surtout, des explications qui m'ont été offertes par eux au fil des années. 


\section{Índice}

Agradecimentos

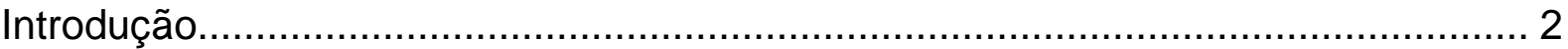

Capítulo I - Entre si... com os outros e contra os outros ...................................... 23

Capítulo II - Outros humanos ............................................................................... 44

Capítulo III - A etnologia das terras baixas sul-americanas diante da morte ........... 58

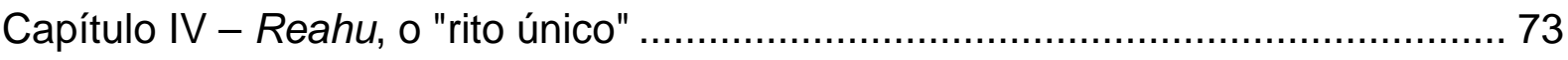

Capítulo V - O outro eu, ou a pessoa yanomami ................................................. 108

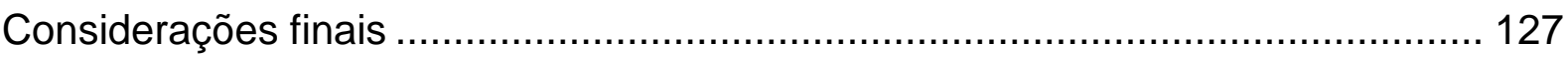

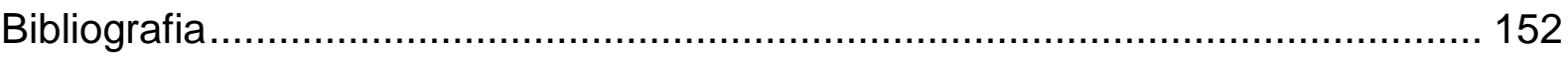




\section{Convenções ortográficas}

Para a transcrição da língua yanomami, adotei as convenções ortográficas elaboradas pelo lingüista Henri Ramirez (1994:46-50); primeiro, porque elas são, sem dúvida, as mais utilizadas no Brasil e, segundo - e é o mais importante, a meu ver -, foram quase que unanimemente utilizadas nos programas de alfabetização em língua materna existentes na Terra Indígena Yanomami, sendo, por isto, reconhecidas e adotadas pelos próprios indígenas.

Ramirez reconhece 18 fonemas, que ele grafa da seguinte forma:

/i / vogal alta, não anterior e não arredondada; sua pronúncia situa-se entre o /i/ e /u/ do português

/ ë / vogal central, não arredondada; sua pronúncia situa-se entre o /e/ e /o/ português; corresponde à grafia $\boldsymbol{\partial}$ do Alfabeto Fonético Internacional

/ e / vogal anterior média, pronunciada como em português, inclusive com as variações livres aberta e fechada

/ o / vogal posterior média, prununciada da mesma forma que em português

/ u / vogal posterior fechada, mesma pronúncia que em português

/ i / vogal anterior fechada, mesma pronúncia que em português

/ a / vogal central aberta, mesma pronúncia que em português

/p / consoante oclusiva bilabial com variação sonora livre, ou seja, pode ser pronunciada como /b/

/ t / oclusiva dental com variação sonora livre (menos freqüente), ou seja, pode ser pronunciada como /d/

/ th / oclusiva alveolar, pronunciada como /th/ inglês em "the" com um leve sopro

/ k / oclusiva pré-velar, pronunciada como /c/ de "carro" em português

/ h / fricativa labial, pronunciada como /h/ inglês em "hair", com uma variação labiodental bem menos freqüente, ou seja, pode ser pronunciada como /f/ português em "faca"

/ x / fricativa palato-alveolar, pronunciada como /sh/ inglês em "share"

/ s / fricativa alveolar, pronunciada como /s/ português em "sapo"

/ m / nasal bilabial, prunciada como /m/ português em "matar"

/ n / nasal alveolar, pronunciada como /n/ português em "nada"

/ r / vibrante alveolar, pronunciada como /r/ português em "caro"

/ w / semivogal bilabial, pronunciada como /w/ inglês em "woman"

/ y / semivogal palatal, pronunciada como /y/ inglês em "yankee" 


\section{Agradecimentos}

Gostaria, antes de mais nada, de expressar minha mais sincera e profunda gratidão aos Yanomami: por tudo o que fizeram por mim, por tudo o que me ensinaram e por tudo o que me deram.

Espero, com este trabalho - mesmo de um modo modesto -, ter retribuído a toda atenção recebida deles: a paciência infinita que sempre tiveram, contando e recontando inúmeras vezes fatos e lembranças que certamente prefeririam ter mantido no esquecimento; as generosas e intermináveis explicações de algo tão evidente para eles, mas que o pesquisador, por sua vez, parecia insistir em não entender; enfim, pelo fato de terem aturado estoicamente a longa presença, às vezes, inconveniente e insistente, de um estrangeiro dentro de sua própria casa e, sobretudo, em ocasiões de profunda consternação, como a de um funeral, e, apesar de tudo, demonstrar um bom humor e uma espirituosidade sem reservas.

Em segundo lugar, certamente, não conseguirei externar em palavras o quão grato sou a minha orientadora, Beatriz Perrone-Moisés, cujo apoio, dedicação, conselhos e ajuda tornaram esta pesquisa possível. Evidentemente - nem seria preciso dizer - todas as limitações e defeitos desta tese são de minha inteira responsabilidade.

Agradeço também aos colegas do Núcleo de História Indígena e do Indigenismo - USP com quem tive a oportunidade e o privilégio de discutir e partilhar reflexões, e que muito contribuíram para o amadurecimento de minha pesquisa sem contar o apoio ilimitado que sempre recebi de todos.

Registro também meu reconhecimento ao corpo docente do Departamento de Antropologia Social da USP que contribuíram grandemente para minha formação.

Agradeço à Capes pela bolsa de doutorado, obtida através do Programa de Pós-Graduação da Faculdade de Filosofia, Letras e Ciências Sociais.

Enfim, sou grato a todos que, de uma forma ou de outra, contribuíram para a realização desta tese. 


\section{Introdução}

Os que a etnologia nomeia de uma maneira geral de Yanomami são, na verdade, os membros de quatro subgrupos culturais e lingüísticos, formando um todo mais ou menos homogêneo que se distingue dos outros povos da bacia amazônica: os Sanima, os Ninam (ou Yanam), os Yanomamë (ou Yanomae) e os Yanomami, que, ao todo, somam um pouco mais de 20 mil pessoas, ocupando atualmente um território de cerca de $200.000 \mathrm{~km}^{2}$ de ambos os lados da fronteira entre a Venezeuela e o Brasil.

Os Yanomami estão distribuídos em seu território em cerca de 350 aldeias e têm um modo de ocupação do solo que varia segundo a região; a densidade demográfica decresce na medida em que nos aproximamos do limite de seu território. Assim, no interior das terras yanomami - a cabeceira do Orinoco (na Venezuela) e a Serra Parima (no Brasil) -, a taxa é de $0,78 \mathrm{hab} / \mathrm{km}^{2}$; nos seus limites, encontramos 0,05 hab/km² (Albert 1992:154).

Caçadores-horticultores sedentários ${ }^{1}$, os Yanomami se inscrevem no conjunto cultural da região das Guianas e, de uma maneira mais geral, partilham os traços culturais e a morfologia social com outros povos da bacia amazônica (Albert 1992: 154; Colchester 1985: 6; Steward 1948: 896).

Até a primeira metade do século XX, os Yanomami só eram conhecidos pelos vários apelidos: "Guaharibos", "Shirishana" ou "Krischana", ou ainda "Waika", etnônimos pejorativos, como costuma ocorrer nesses casos, imputados por outros grupos. Foi somente por volta dos anos 1920 que, pela primeira vez, o etnólogo Koch-Grünberg (1966 [1924], III: 239-267) postulou a uma certa homogeneidade cultural dos Yanomami - se bem que ela já fosse suspeitada por outros exploradores da região. Koch-Grünberg recolheu o primeiro léxico entre os

\footnotetext{
${ }^{1}$ Para uma discussão sobre sedentarismo/nomadismo/mobilidade das sociedades das terras baixas, ver Crépeau 1993.
} 
Yanomami orientais e propôs também a unidade das línguas e dialetos falados pelo conjunto dos Yanomami.

Em relação às línguas yanomami, destacam-se os estudos dos lingüistas Ramirez (1994) e Migliazza (1972, 1980). Seguirei a descrição de autoria de Ramirez, que revê a base estabelecida por Migliazza a partir do aprofundamento no conhecimento da língua e dela difere. Primeiramente, Ramirez considera que o yanomamë (oriental) e o yanomami (ocidental) não são duas línguas distintas, mas sim dialetos de uma só língua, mais precisamente três subgrupos de dialetos: Yoc, Yor e Yba. Além disto, Ramirez desmembra o ninam (ou yanam) em duas línguas, chamadas de divisão $\mathrm{A}$ e divisão $\mathrm{N}$; a divisão $\mathrm{A}$ (de Ajarani, região onde é falada, e que poderia ser denominada yawari) corresponde, segundo ele, a uma quarta língua, circunscrita à região do alto Ajarani e Médio Catrimani, no Brasil, que ainda não foi objeto de estudo aprofundado ou descrição mais completa ${ }^{2}$. No mais, a classificação de Ramirez coincide com a de Migliazza. Apesar de muito antigo, e portanto desatualizado em termos demográficos, reproduzo o quadro com as quatro divisões da família yanomami, seus dialetos e seus respectivos números de locutores, tal como proposto por Ramirez (1994:25):

\footnotetext{
${ }^{2}$ O leitor notará que mantive no texto as pequenas diferenças fonéticas entre os dialetos oriental e ocidental, como no caso do sufixo -teri ou -theri ou em palavras onde o fonema /i/ é substituído por /ë/, por exemplo.
} 


\section{Quadro 1 - Divisão da família lingüística yanomami}

número aproximado

de locutores (1993)

\section{Divisão S (sanuma)}

dialeto $\mathrm{S} 1$ dialeto S2

dialeto S3

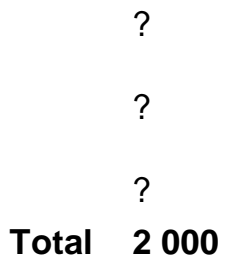

$?$

Total 2000

\section{Divisão Y (yanomami)}

dialeto Yor-c 1300

dialeto Yor-x 1700

dialeto Yor- $f$ 1100

dialeto Yba $500(?)$

dialeto Yoc- $f$ 4500

dialeto Yoc-norte 3400

dialeto Yoc-sul 4800

Total 17300

\section{Divisão N}

dialeto Nnorte 260

dialeto Nsul 380

Total 640

\section{Divisão A}

dialeto $\mathrm{A} 1$ 300

dialeto A2

Total 360 
Do ponto de vista etnológico, apesar das diferenças lingüísticas, os Yanomami são considerados em bloco, com base precisamente na idéia de uma unidade lingüística. O grupo assim delimitado, muitas vezes chamado de tribo, etnia, etc, é mais um exemplo de unidade discreta cuja pertinência em termos descritivos e analíticos tem sido cada vez mais discutida. Voltaremos a esse ponto mais adiante.

Se perguntarmos a um yanomami o que ele é, muito provavelmente, ouviremos a resposta esperada de que é um deles, um yanomami - com algumas variações, pequenas e grandes, no termo empregado: yanomami, yanonami, yanoama, yanomae, yanomamë, sanima, yanam etc. Mas tanto a pergunta quanto a resposta só fazem sentido dentro do contexto em que os Yanomami se relacionam conosco e, principalmente, só fazem sentido em português. Entre eles, outras são as perguntas e respostas quando se trata de auto-identificação. Aliás, como em muitos casos de etnônimos ameríndios, yanomami (e os demais termos afins) designa, de uma maneira geral, a condição humana, por oposição a outras, ou seja, quer dizer "gente" (cf. Lizot s/d: 620; Lizot 1976:9).

Assim, ao menos espera-se de alguém que é capaz de formular de maneira inteligível uma pergunta a um yanomami que ele não tenha dúvida, em princípio, da condição humana de que seu interlocutor - condição de gente que, diga-se de passagem, tem como traço distintivo fundamental a fala, a capacidade de se comunicar. Porém, nas interações com a sociedade nacional, com os napë (nãoyanomami), o termo passou a indicar a identidade indígena do grupo, em oposição aos não-indígenas e aos outros indígenas não-yanomami - demarcando-se como grupo específico dentro da categoria genérica "índio".

Isso posto, dentro da cosmologia do grupo, a categoria yanomami - como qualquer categoria, afinal - não ser pode definida no absoluto, sendo seu significado sempre relativo ao contexto em que é utilizada. Além disso, ainda que admitíssemos que o termo define ou delimita a humanidade, simplesmente adiaríamos a questão, que passaria então a ser: o que é, no caso em questão, "humanidade"? Ou ainda: o que não é em nenhum aspecto ou não foi algum dia yanomami? Mas a isso voltaremos mais adiante. 
Intragrupo, os marcadores de identidade/alteridade nos remetem a categorias que mobilizam outros referentes, a partir de um gradiente de que a aldeia, ou o grupo de residentes cognatos, é o ponto de partida. O ponto final seria a categoria napë, o limite extremo de uma rede de relações entre humanos em que, quanto mais nos afastamos do centro - nível zero da alteridade, por assim dizer - menos podemos esperar de nossas relações. Mas existe também um terreno intermediário, justamente onde tudo podemos esperar de nossas relações. E esta ambigüidade encerra, é claro, um aspecto também positivo. Ou seja, entre a alteridade zero e a máxima, existe todo um espaço intermediário, onde a diferença assume uma valência positiva, onde a afinidade e a aliança dão seus frutos, questão a que voltaremos ao abordarmos os contextos de oposição e aliança.

No plano sociológico, podemos resumir assim o léxico do idioma da alteridade: kamiyë yamaki, nós (os cognatos co-residentes e aliados partilhando a mesma origem); nohi thë pë, aliados; xõmi thë pë, outros (outros grupos com os quais não se matém nenhuma relação), napë pë (forasteiros, inimigos), tano mai thë pë, desconhecidos; yai thë pë, de natureza desconhecida. Estas categorias podem ainda ser recortadas no seu interior. Por exemplo, em kamiyë yamaki, nós, é possível referir-se exclusivamente aos co-residentes, yahiteri ou yahiterimi, distinguindo-os dos membros de outras aldeias fazendo parte do mesmo grupo aparentado; ou ainda napë kraiwë pë para referir-se aos Brancos, ou seja, forasteiros não-índios (é muito provável que o termo kraiwë tenha sua origem no caraíba tupi; Ramirez, comunicação pessoal).

Antes de prosseguir, peço licença para abrir um parêntese e descrever de um ponto de vista pessoal alguns aspectos de minha experiência de vida com os Yanomami.

Numa tarde úmida e quente de maio, quase duas horas depois de ter decolado do aeroporto de Boa Vista, em Roraima, o pequeno avião monomotor, abarrotado de caixas de remédios, material de construção, botijões de gás etc., 
inicia o procedimento de aterrissagem. Mal enxergamos a pista lá embaixo: um fiapo de terra no verde da selva. Para o piloto, experimentado durante a febre do garimpo em Roraima, e que já viu pistas e condições de vôo bem piores, tudo não passa de uma rotina tranqüila e monótona. Em Roraima, finda a febre do garimpo, muita gente se reciclou, deixando o ouro e diamantes para explorar as atividades relacionadas aos povos indígenas.

Aterrissamos na pista de terra, ainda molhada, já no Estado vizinho do Amazonas. Com cerca de 600 metros de comprimento, a pista de pouso tinha ainda uma pequena colina plantada no meio; ou seja, de uma cabeceira não se via a outra! De qualquer maneira, na época, minha ignorância a respeito do assunto não me permitia ter consciência do perigo que correra. Mal tínhamos aterrissado quando uma pequena multidão de índios seminus e curiosos cercou o avião. Percebi, em seguida, uma maloca, ou xapono como se diz em yanomami, ao lado da pista. Foi só então que me dei conta de que tinha entrado em outro planeta, o planeta Urihi (termo que abriga vários conceitos na língua yanomami, entre eles o de Terra), no qual viveria boa parte dos dez anos seguintes de minha vida.

Só muito mais tarde tudo se tornaria mais ou menos familiar. Mas naquele momento, a maior parte das coisas, as relações, as instituições, as circunstâncias etc., ainda causavam enorme estranheza. A paisagem urbana desaparecera para dar lugar à floresta. Não havia ruas, edifícios, automóveis e outros itens da natureza humanizada das cidades e eu viria a descobrir, não sem alguma pena, que meu corpo fora adestrado unicamente para ela. $\mathrm{O}$ ambiente rural tampouco corresponde ao que estamos acostumados a ver na região do sudeste brasileiro: são campos nus, desmatados, onde alguns bois preguiçosos nos olham sem interesse... Dentro da floresta, nem o céu se consegue ver. Uma infinidade de árvores de inumeráveis espécies ocupa claustrofobicamente todo o espaço. Confesso que me senti, logo de início, razoavelmente oprimido pela floresta e bastante intimidado por aquela pequena multidão risonha de índios nus.

Desembarcado no Brasil, algumas semanas antes, vindo do Québec, no Canadá - onde passara alguns anos fazendo o mestrado -, na verdade, conseguia sofrivelmente aturar a nova natureza que me cercava: o calor para mim era ainda 
insuportável, tanto quanto as picadas de uma miríade de insetos, tão variados quanto intoleráveis, piuns, mutucas, carapanã, mucuim etc. Precisei de alguns meses para me habituar.

Ainda hoje não sei se, para nós, é o espírito ou o corpo que mais demora a habituar-se à floresta. Por sorte, no que diz respeito ao espírito, o bom humor yanomami sempre foi de grande socorro nas horas mais difíceis. As atividades cotidianas, assim como as relações pessoais, são invariavelmente temperadas por gracejos, observações irônicas, ou por comentários impudicos com significado abertamente sexual. Somente bem mais tarde, com o aprendizado da língua, pude desfrutar mais largamente dessa qualidade do caráter yanomami. Aliás, com o passar do tempo, dei-me conta também da grande competência retórica dos líderes e anciões; é de cair o queixo! Ao ouvi-los discursar, sempre imaginava o papel que alguém com tal maestria oratória poderia desempenhar em nossa própria sociedade: educador, político... Mas disso, só pude desfrutar bem mais tarde, quando já dominava razoavelmente a língua.

Comecei então as minhas visitas às comunidades existentes na região do alto Demini. Lembro que, desse período, o que me marcou bastante foram as longas caminhadas através da floresta; é através delas que se entra na mata, mas, em certo sentido, é também assim que a mata entra em você. Contudo, caminhar na mata, mesmo através das trilhas yanomami, não é de maneira nenhuma fácil para quem andou a vida toda nas cidades, sobre calçadas e ruas pavimentadas. Tive, de certa forma, que reaprender a andar: evitar raízes e buracos, saltar os obstáculos do terreno sempre irregular, equilibrar-me sobre troncos, vadear brejos e alagados e, sobretudo, manter o equilíbrio. Cedo, dei-me conta do risco que representava escorregar ou tomar uma queda - quase inevitável em um caminho de barro sempre molhado pela chuva. Na maioria das vezes, o pior tormento não era a própria queda, mas o fato de, no reflexo de evitá-la, a mão sempre procurar um apoio no tronco mais próximo e muitas vezes encontrar o tronco de alguma palmeira coberto de espinhos compridos, que espetam a carne às dezenas, causando um sofrimento insuportável. Além, é claro, de constituir uma fonte de diversão renovada para meus companheiros de caminhada. 
Outro problema relacionado às caminhadas diz respeito ao que calçar. Depois de muito experimentar, acabei optando pelas sandálias havaianas, adotadas, aliás, com muito entusiasmo pelos próprios Yanomami. É que botas e tênis acabam sempre encharcados de água e lama e cheios de terra no interior, o que provoca calos horríveis. No final das contas, os pés ficam repletos de feridas e, além do mais, desprotegidos, já que as feridas o impedem de calçá-los. Ao contrário, as sandálias não provocam calos ou feridas nos pés e se pode simplesmente tirá-las para atravessar os brejos e regiões alagadas. O que, na verdade, representa sua única desvantagem: na água, estamos descalços, desprotegidos contra os espinhos. Como já disse, tive que reaprender a andar; não temos o costume de caminhar o dia inteiro - ainda mais nessas condições - e nem sempre a condição física para tanto. E como no início não podia conversar com os yanomami, companheiros de marcha, não me restava outra ocupação durante as andanças além da contemplação da floresta, o que me dava uma certa calma para enfrentar as dificuldades da jornada.

Os caminhos da floresta - pelo menos os yanomami - são exíguos, uma picada apenas, e sobretudo tortuosos. Mais tarde, entendi o porquê: é que quando uma árvore cai e atravessa a trilha, raramente é removida ou cortada. Contorna-se simplesmente o obstáculo e segue-se em frente. Mas como, com o passar dos anos, os obstáculos se multiplicam, o traçado do caminho que algum dia já foi mais ou menos reto torna-se algo parecido com uma serpente retorcida. Evidentemente, o trajeto, com isso, fica muito mais longo. Lembro-me que, mais tarde, quando a aldeia dos weyokiweiteri ${ }^{3}$ passou a ser visitada pelo pessoal de saúde do posto do Alto Demini, pedimos aos Yanomami que refizessem a picada, que já estava quase abandonada, e que evitassem então as curvas e rodeios existentes. O percurso diminuiu quase para a metade - ao invés de caminharmos 11 horas passamos a fazê-lo em apenas cinco ou seis horas!

Não se atravessa a floresta aleatoriamente para ir de um ponto a outro: os arbustos, os espinhos, os cipós e outros obstáculos tornariam o trajeto um suplício. Assim, há sempre uma teia de trilhas ligando cada aldeia a outra, cada região a

\footnotetext{
${ }^{3}$ Comento os termos de auto-referência mais adiante.
} 
outra. Trilhas antigas, incontáveis. Seu estado depende da importância e do uso que delas fazem os Yanomami. Como sabemos, a região do Alto Orinoco e do Alto Rio Negro há séculos, é cortada por uma rede de caminhos que levavam e traziam produtos dos Andes, Caribe e bacia do Amazonas. Outros povos utilizam canoas para o transporte e locomoção. Não é o caso dos Yanomami do leste do Amazonas e de Roraima, ou, pelo menos, da maioria deles. Habitando uma região de serras e de pequenos cursos d'água, não dispõem de barcos ou canoas e, regra geral, evitam a todo custo nadar nos rios ou lagoas, pois não se sentem à vontade na água - meio hostil e habitado por seres sobrenaturais nada amigáveis. É bem verdade que existem monstros e bestiolas bem reais nos rios da Amazônia: o poraquê, ou peixe elétrico; as raias, cujos ferrões podem provocar ferimentos doloridíssimos e que custam a curar; a sucuriju, a cobra gigante que esmaga suas presas antes de engoli-las, o jacaré-açu etc. Sendo assim, se precisamos ir a algum lugar na urihi (aqui "floresta"), só podemos contar com os próprios pés.

Certa feita, depois de todo o dia caminhando, estava prestes a alcançar meu destino, uma pequena aldeia razoavelmente afastada do posto de saúde, onde estava hospedado desde que chegara na floresta havia alguns dias. A companhia de dois yanomami não me fora de grande valor: mal conseguia articular uma dúzia de palavras em sua língua e eles também não compreendiam efetivamente o português, o que tornava nossa relação algo bem árido. Além disso, o passo apressado de meus guias me fizera sofrer bastante; acompanhava-os pagando um duro preço: tropeções, quedas e muitos arranhões. Mas, finalmente, ao cair da tarde, aproximamo-nos da aldeia. Quando já havíamos atravessado o rio Demini, que corta a floresta próximo à aldeia, e já podíamos avistá-la, meus dois acompanhantes imobilizaram-se por um momento e trocaram um olhar em que se mesclavam curiosidade e preocupação. Alguns passos adiante, entendi o motivo: um coro de choro e lamentações brotava da maloca, inundando todo o lugar com uma enorme tristeza - que juntada à melancolia do pôr-do-sol, fez com eu que me arrepender de estar ali naquele momento.

Não estava, decididamente, preparado, àquela altura, para participar de um funeral de uma gente da qual, no atacado e no varejo, desconhecia quase tudo 
(mesmo na nossa cultura e no nosso círculo pessoal, a situação já nos causa um tremendo embaraço). No entanto, o desespero dos choros e a veemência das lamentações não supunham outra coisa: a tragédia maior, irremediável e última que persegue todo ser vivo: a morte estava presente entre aquela gente... Devo lembrar também que, além de chegar em um mau momento, não tínhamos sido convidados; a visita imprevista era uma idéia minha. Apesar disso, uma retirada estava fora de questão: não conseguiria sequer convencer meus guias a retornar ao posto, e ainda que eles concordassem, não seria mais possível, pois restavam-nos apenas alguns minutos mais de claridade, antes de a floresta mergulhar em uma escuridão povoada de perigos. O embaraço e a contrariedade ganharam também meus companheiros de jornada e, estóicos, andamos os três até a aldeia da maneira como devem caminhar os condenados para a forca ou para a cela depois de ouvir suas sentenças.

Felizmente, até mesmo a adversidade tem limites. Tratava-se realmente de um funeral, mas não de um ser humano e sim de um cachorro, ótimo caçador, muito estimado pelos seus donos, em particular, e por todos, de uma maneira geral. Os prantos e as lágrimas eram tão reais quanto sinceros e, de fato, no dia seguinte depois de uma noite inteira de velório, se me permitem o termo -, o cachorro foi cremado em um ritual bem parecido com o que é reservado aos humanos. Iniciei, assim, o meu aprendizado da cultura yanomami - na qual as relações entre os homens e os animais, como veremos adiante, é tão surpreendente quanto complexa...

Havia também algo de premonitório neste evento: fiquei impressionado pelo pequeno drama que se desenrolara na aldeia e pela atmosfera de profunda melancolia que a morte produzira naquela gente e dei-me então conta de sua importância para os Yanomami. Posteriormente aprenderia que a morte e tudo o que está relacionado a ela se impõe de maneira decisiva, determinando quase todos os níveis da vida yanomami. Tive também, infelizmente, a oportunidade de presenciar outros funerais, de gente como a gente, e acompanhar o luto. Isto me marcou ainda mais profundamente, confirmando minha primeira impressão. 
Na manhã do dia seguinte, depois de uma noite mal dormida, um temporal que parecia não ter mais fim tirou o que restava de ânimo a todos; toda atividade social após o funeral do cachorro foi se contraindo, até finalmente reduzir-se a se balançar nas redes e a requentar algo comestível nas fogueiras. Confesso que não fiquei nem um pouco aborrecido com esse marasmo; permaneci encolhido discretamente em minha rede, recuperando-me da fatigante caminhada da véspera e da noite em claro, e desfrutando preguiçosamente da oportunidade de observar de dentro o quotidiano de uma aldeia yanomami.

Entretanto, por volta de 11 horas da manhã, a água do rio subira tanto que já inundava boa parte da roça que cercava a maloca. Os meus anfitriões, já prevendo o pior, começaram então a fazer suas bagagens. E estavam certos. A chuva não parou. Ao meio-dia, a água já cobria todo o chão da casa comunal e continuava a subir. Não havia um minuto sequer a perder: era preciso atravessar o mais rápido possível o rio e ganhar o caminho para a comunidade vizinha, se não quiséssemos dormir debaixo de chuva em um acampamento improvisado na floresta.

É inacreditável como os rios da Amazônia podem subir ou vazar em questão de horas! Naquela manhã, a cheia atingira, pelo menos, quatro metros. $E$ a correnteza? Admito que quase me afogo ao jogar-me nas águas para tentar salvar algo parecido com uma canoa, que afinal acabou sendo levado pela correnteza. Tratava-se, na realidade, de um grande tronco de árvore oco, que os Yanomami utilizam para armazenar a grande quantidade de mingau de banana que é preparada durante as festas. Mário ${ }^{4}$, o guia mais arrojado, tentara utilizar o grande recipiente como uma embarcação. Demonstrara tanta confiança que acabei mesmo acreditanto no sucesso da empreitada. Sua tentativa, no entanto, durou apenas

\footnotetext{
${ }^{4}$ Os Yanomami, como acontece na maioria dos povos ameríndios - se não todos - possuem nomes cristãos, atribuídos por missionários, garimpeiros, agentes de organismos governamentais etc., normalmente utilizados em contextos de contato com estrangeiros. Os nomes próprios yanomami, que são vários ao longo da vida, costumam ser utilizados apenas durante a infância, sendo banidos do uso durante a puberdade. No contexto das relações intracomunitárias, empregamse termos de parentesco, sendo a utilização de nomes próprios absolutamente interdita, uma interdição que se torna ainda mais forte após a morte do indivíduo. Neste texto, utilizo apenas nomes cristãos. Acerca da onomástica yanomami, ver Lizot 1973; Ramos 1990, cap. 8.; Albert 1985: 394404.
} 
alguns segundos: o tronco oco emborcou logo após entrar na água e Mário só não foi levado pela correnteza porque se agarrou imediatamente à vegetação da margem e conseguiu sair da água. Em um arroubo de bravura e solidariedade - cujo propósito até hoje me parece obscuro - joguei-me à água para recuperar a inútil canoa. Instantaneamente, a exemplo de Mário, dei-me conta de que a única coisa a fazer era agarrar-me de qualquer maneira e o mais rápido possível à vegetação da margem se não quisesse seguir o mesmo destino da canoa, ou seja, ser levado rio abaixo pela correnteza. Acostumado com as praias tranqüilas do Espírito Santo, não era ainda familiar às águas de rio, mais traiçoeiras, não tomando as precauções de meus anfitriões yanomami.

Enfim, um longo cipó, levado até a margem oposta onde foi amarrado a uma estaca, nos serviu de ponte. Agarrado com todas minhas forças a ele, levando comigo uma mochila carregada de roupas, redes, cadernos e livros, agora totalmente encharcados, atravessei milagrosamente o curso do rio para ganhar um brejo que se formava na margem oposta, onde quase não havia correnteza.

Caminhamos o restante do dia pela floresta inundada, com água pela cintura, até alcançarmos, já de noite, o posto de onde saíramos na véspera: meus colegas de jornada, depois de todo esses infortúnios, decidiram dar por terminada minha primeira e sucinta experiência etnográfica propriamente dita e retornar para sua aldeia, situada em frente ao posto, ao lado da pista de pouso, ao invés de seguir para outra maloca. Devo revelar que fiquei um pouco envergonhado e atrapalhado para explicar aos funcionários do posto - admirados com a rapidez de minha viagem - os motivos de tão breve retorno.

Curiosamente, guardo ainda a impressão de que o mais difícil na experiência com os ameríndios é atravessar a ante-sala da aldeia: seja o posto da Funai, da Funasa (Fundação Nacional de Saúde), a missão religiosa, ou ainda o posto da ONG. Percorrer o labirinto do indigenismo nem sempre é fácil; e não podemos evitálo, pois toda relação com os povos indígenas é, pelo menos de início, intermediada pelas instituições (nacionais e estrangeiras) que gravitam em torno deles. Quando 
pretendemos entrar em terra indígena temos, necessariamente, que obter um visto ou permissão de entrada da Funai; ademais, vemo-nos obrigados a ser ciceroneados pela instituição existente na região, missão, ONG ou outra - que, premeditadamente ou não, filtra toda relação dos índios com o resto do mundo e vice-versa.

Além da FUNAI, encarregada da política indigenista governamental, e das missões religiosas católicas e protestantes, existem também, há algumas décadas, organizações não-governamentais que se especializaram na questão indígena. Pretendem defender institucionalmente os direitos políticos e sociais dos povos indígenas e atuam ademais em áreas específicas como saúde e educação, executando programas geralmente financiados pelo próprio governo ou por organizações internacionais.

No final da década de 90 e início de 2000, havia no Brasil, além das missões religiosas, quatro organizações não-governamentais atuando entre os Yanomami: a Comissão Pró-Yanomami (a CCPY, antes denominada Comissão pela Criação do Parque Yanomami, daí a sigla), precursora das três outras; a Secoya (Serviços e cooperação com o povo yanomami), atuando principalmente nas comunidades do rio Marauiá; e o IBDS, (Intituto Brasileiro de Desenvolvimento Sanitário), que surgiu do Institut de Développement Sanitaire, organização francesa que atuou durante alguns anos no Estado do Amazonas; e a Urihi - Saúde Yanomami, que surgiu do desmembramento do programa de saúde da própria CCPY. As duas últimas desenvolveram principalmente atividades de assistência à saúde e são totalmente financiadas pela Fundação Nacional de Saúde do Ministério da Saúde.

Minha experiência com os Yanomami iniciou-se através da CCPY, onde tive a oportunidade de aprender muito do que precisei mais tarde para viver na floresta em companhia dos deles. Fui inicialmente convidado a participar do programa de saúde. Cursava então o mestrado na Universidade de Montréal (Québec, Canadá). Troquei correndo o inverno polar do Québec - mais ou menos 25 $\mathrm{C}$ abaixo de zero - pelo calor tórrido do equador. Tinha certeza de que a experiência enriqueceria minha formação acadêmica - na verdade, com o passar do tempo, acabei pondo o mestrado em segundo plano. Finalmente, não tive uma participação efetiva no 
programa de saúde e permaneci livre para estudar a língua yanomami. Apesar de a ONG arcar com minha alimentação e transporte na floresta, cobri todas despesas da viagem - o que me custou alguns milhares de dólares. Confesso, no entanto, que minha posição era bem cômoda. Não tinha, na verdade, compromisso profissional nem acadêmico rígidos. Dispunha de meu tempo como bem entendia. Combinava o papel do acadêmico com o do explorador ou mesmo do turista: perambulava com os Yanomami pela floresta, pescava, caçava. Entre o etnólogo propriamente dito e o turista, cujas posições Todorov (1982: 313) distingue em termos de fecundidade respectiva ${ }^{5}$, eu me encontrava numa situação intermediária, que talvez possa ser comparada à dos famosos truchements normandos do século $\mathrm{XVI}{ }^{6}$. Como eles, eu migrara de corpo e alma para outro universo cultural e, imerso na vida da sociedade que me acolhia, me distanciava da experiência passageira e superficial do turista. Ao mesmo tempo, não tinha as obrigações do etnógrafo, que se aproxima do truchement na medida em que participa ativa e intensamente da vida da comunidade que o acolhe mas, justamente, porque esse constitui um de seus deveres, como bem se sabe desde que Malinowski (1922) estabeleceu os fundamentos de um bom trabalho de campo .

Foi apenas na minha segunda estadia que minhas atividades passaram a ser pautadas por obrigações específicas. Em 1998, atuei no programa de Educação da CCPY, o que tomou todo o meu tempo. Dois anos mais tarde, participei do programa de assistência à saúde da organização não-governamental Urihi, financiada pela Fundação Nacional de Saúde-Ministério da Saúde e, ainda depois, tive a oportunidade de trabalhar como consultor do Departamento de Saúde Indígena (Desai) da Funasa para o Distrito Sanitário Especial Indígena Yanomami.

Assim, a participação no programa de educação da CCPY e, mais tarde, nos de saúde, desenvolvidos no âmbito do distrito sanitário, possibilitou-me passar

\footnotetext{
5 "Enfim, a posição do etnólogo é fecunda; bem menos é a do turista que a curiosidade pelos costumes estrangeiros leva até a ilha de Bali ou à periferia da Bahia, mas que encerra sua experiência do heterogêneo no espaço de suas férias pagas. É verdade que, ao contrário do etnólogo, ele paga sua viagem de seu próprio bolso". (Todorov 1982:313).

${ }^{6}$ Sobre os truchements (intérpretes) nas colônias francesas, ver Perrone-Moisés 2008:57-58.
} 
alguns anos em terra yanomami, no leste do Estado do Amazonas e oeste de Roraima, onde vive a maioria dos Yanomami brasileiros. Tive tempo suficiente para aprender bem duas das quatro línguas yanomami e conhecer o modo de vida e a maneira de pensar desse povo. Fiz de tudo um pouco; trabalhei como educador no programa de alfabetização em língua materna, como intérprete, e depois como assessor, quando o programa de saúde da CCPY ganhou autonomia, tornando-se uma ONG à parte, adotando o curioso nome de Urihi - Saúde Yanomami. Mais tarde ainda, atuei como consultor do Departamento de Saúde Indígena (Desai) da Fundação Nacional de Saúde e também como antropólogo do Distrito Especial Indígena Yanomami, através da Fundação Universidade de Brasília. Tive então a possibilidade de conviver longamente com os Yanomami da Serra Parima, em Roraima.

O processo de aprendizagem do mundo yanomami foi, evidentemente, bastante lento no início, quando as dificuldades de comunicação impossibilitavam a coleta de informações e a interação com os yanomami, que, na região onde estava, sem exceção, falavam somente sua própria língua, não possuindo nenhum conhecimento do português. Não tive outra escolha senão a de aprender o mais rápido possível a língua yanomami. Aprender uma outra língua é sempre difícil, mas o é ainda mais quando se trata de uma língua que, como é o caso, possui uma estrutura completamente diferente daquela que se fala. No caso, por sorte, a fonética da língua yanomami é relativamente simples e próxima à do português, o que facilita enormemente as coisas, e não se trata de uma língua tonal, à diferença de várias línguas ameríndias ou asiáticas. Mas apresenta dificuldades próprias, como, por exemplo, as variações não significativas de um mesmo fonema: /p/ e /b/, /t/ e /d/, /r/ e /l/, /h/ e /f/ (cf. Ramirez 1994:46ss). Por exemplo, para o termo que corresponde à ancião, velho ou grande, em yanomami pode-se pronunciar pata, bata, bada ou ainda pada; essas variações não mudam o significado da palavra e temos de nos habituar a ouvi-las. As línguas da família yanomami, além disso, possuem uma série, fundamental, de referenciais espaço-temporais. Importa sempre especificar se uma ação ou movimento dá-se de forma centrífuga ou centrípeta em relação a quem fala, se a ação se desenvolve em um só ou em vários lugares, se é simultânea ou paulatina etc. Tudo isso devendo ser acusado através de sufixos que 
são agregados aos verbos e às orações; estes, somados aos classificadores - que seguem todo nome - tornam as palavras quase indecifráveis, mergulhadas em um mar de sufixos e posposições. Por exemplo: xi wãri quer dizer estar em apuros ou com mal-estar; já ouvi a seguinte frase: (ukuxi pënt) a xi wãri-ma-re-tayo-ma-he, onde cada um dos cinco sufixos acrescenta um sentido a mais ao fato, que é o seguinte: os piuns a fizeram sofrer lá longe. Em suma, é preciso aprender a conhecer e reconhecer toda uma série de sufixos antes de ser capaz de compreender qualquer afirmação em yanomami. Outras especificidades podem ser mencionadas, como o pronome dual (nós dois, vocês dois, eles dois) e a distinção entre a primeira pessoa do plural (nós) inclusiva (nós, inclusive você com quem falo) e a exclusiva (nós, excluindo você com quem falo). No mais, o Yanomami é, até o presente, considerado como uma família isolada e não foi vinculada a nenhum tronco lingüístico. As tentativas de fazer isso não foram de nenhuma maneira conclusivas (Ramirez 1994:26-30; Albert 1985:35-38, 43-49), embora o próprio Ramirez (1994:26) considere que o yanomami possui várias semelhanças com as línguas arauaques, sobretudo com o bahuana/čiriana.

O fato de não haver, naquela época, nenhum yanomami na região que compreendesse razoavelmente o português tornou o aprendizado da língua uma tarefa mais árdua, na medida em que não podia dirimir minhas dúvidas, nem sequer transformá-las em questões que pudessem ser respondidas. É bem verdade que o início foi difícil, muito difícil... De um lado, eu, um estranho (ou estrangeiro) com um vocabulário que não ultrapassava uma dúzia de palavras, tentando, a duras penas, manter algum tipo de comunicação; de outro, ou bem um yanomami que me tratava como se fosse um deles, falando normalmente e se comportando como se eu entendesse tudo, ou bem um impaciente interlocutor que não compreendia como um ser humano dotado de razão podia não compreender a sua língua, o yanomami, e falar uma linguagem bárbara; profundamente aborrecidos, muitos de meus interlocutores simplesmente perdiam o interesse por nosso arremedo de conversa.

Por outro lado, esse contexto obrigou-me a viver uma imersão completa na língua yanomami, o que apressou enormemente meu aprendizado. Confesso também que a tarefa foi bastante facilitada por um pequeno manual de 
aprendizagem do yanomami ocidental preparado por Ramirez (1992) para a Diocese de São Gabriel da Cachoeira, no Amazonas, que, milagrosamente, me caíra nas mãos durante o terceiro mês de minha estadia. Até então, só dispunha de um outro manual que o próprio Ramirez produzira para a Diocese de Roraima sobre o yanomami oriental - uma outra língua (ou superdialeto, como classifica o próprio Ramirez) das quatro que compõem a família yanomami. Era um pouco como aprender português com um método de espanhol. Entretanto, mais tarde, dei-me conta de que estava justamente na fronteira lingüística entre os dois grupos, ocidental e oriental e que a língua que se falava ali estava como que a meio caminho entre as duas faladas por cada um dos dois grupos. Também aqui, a dificuldade inicial transformou-se em benefício mais tarde, pois acabei me familiarizando com as duas línguas.

Para complicar um pouco mais as coisas, os Yanomami e os brancos comunicavam-se invariavelmente através de um pidgin paupérrimo, um arremedo de língua com uma estrutura tão elementar que não possui flexão verbal e um vocabulário tão reduzido quanto estereotipado. Esse pidgin não é português, nem yanomami, mas cada lado pensa que é algo bem parecido com a língua do outro.

No inverno de 1996, a missão Novas Tribos no Novo Demini foi responsável pela instalação, na pacata região de Rohikatiopë-u de uma verdadeira febre entre os jovens yanomami pela escrita. Isto transformou meu aprendizado da língua em um verdadeiro inferno: não podia mais abordar um yanomami com o gravador e meu caderninho debaixo do braço, sem que nossa conversa se dirigisse invariavelmente para as maravilhas e os segredos da escrita fonética. E pior: tinha que repetir infinitas vezes o "a-e-i-o-u". A verdade é que até então eu nunca tinha refletido sobre o processo de aprendizado e aquisição da escrita e minha pedagogia era de fazer qualquer educador cair em prantos. Devo também admitir que a distribuição entre meu público de um punhado de cadernos e lápis, que inadvertimente eu fizera vir de Boa Vista, foi a pior decisão que eu podia ter tomado. Esperava com isso livrar-me dos mais obstinados, que, pensava eu, se entreteriam a tentar desenhar as letras, e eu poderia assim continuar, de meu lado, meu próprio estudo da língua, sem ter que 
tentar dar explicações a respeito da escrita - que eu desconhecia e, de todo modo, não teria sido capaz de exprimir em yanomami. Mas, então, com o aparecimento dos cadernos e lápis, os que até então não davam a mínima para aquela história de esicrevemou (como chamavam a atividade da escrita), acabaram se convencendo de que escrever era uma atividade imprescindível para acompanhar os tempos e que não poderiam ficar de fora dessa novidade.

Esse episódio provocou a indignação da direção da CCPY que, muito a propósito, exigiu-me esclarecimentos por tal ato; por que, sem nenhuma autorização da coordenação programa de educação (que já existia em outra aldeia) e sem qualquer método, eu afinal tinha resolvido "brincar" de alfabetizar os Yanomami? Veio-me então ao espírito uma advertência que ouvira de um professor na Universidade de Montréal, em tom recriminatório: "A alfabetização representa senão uma violência, ao menos um perigo para as sociedades tradicionais sem escrita". Outra lição tem de ser incorporada para pensar esse tema que, desde então, passou a me interessar. Essa "estranha coisa que é a escrita", como diz Lévi-Strauss, parece sempre estar ligada, lembra ele, à instalação de hierarquias e a relações de poder, e assim fora entendida e utilizada pelo chefe Nambikwara que fingia dominar a escrita para melhor estabelecer sua posição em relação aos seus (Lévi-Strauss 1955:340-345). Uma série de outros exemplos poderiam ser invocados, entre ameríndios, de pessoas cujo interesse pelo domínio da escrita está diretamente ligado à aquisição de um certo controle na relação com os brancos e instaura diferenciações internas.

Mas voltemos aos cadernos: agora, sentia-me como se tivesse passado do papel de caçador para o de caça. Ao invés de aborrecer os Yanomami com minha obsessão pela língua deles, perguntando o nome de tudo, como se dizia isso e aquilo, como se pronunciava corretamente tal fonema, era o contrário que ocorria. Essa foi minha primeira experiência com alfabetização entre os Yanomami e, na época, eu nem desconfiava que essa atividade se constituiria em minha preocupação principal alguns anos mais tarde. De todo modo, os cadernos acabaram sendo consumidos com uma rapidez proporcional à avidez pela escrita e, 
assim, de uma maneira egoísta, pude ir me esquivando desse interesse e dedicarme ao meu próprio negócio, que era o aprendizado do yanomami.

Para mim já era imensamente difícil aprender a língua yanomami naquelas condições. Sem um interlocutor que falasse português e pudesse dirimir minhas dúvidas, eu era obrigado a encontrar as respostas sozinho, sempre através de um longo e penoso processo de reflexão e dedução - que muitas vezes conduzia a uma conclusão totalmente fantasiosa, como eu viria a perceber ao longo dos anos. Tampouco dispunha de um método ou material didático adequado, como já comentei. Ainda por cima, levava um tipo de vida em que a disciplina era solapada a todo instante.

Ao longo dos muitos anos, acabei aprendendo a entender e a falar; sou capaz, hoje, de fazer um discurso sem que meus interlocutores yanomami caiam na gargalhada. Quanto mais se aprende uma língua (e provavelmente qualquer coisa), mais se tem noção do tamanho da própria ignorância, do que sempre haverá para aprender. No caso específico dos Yanomami, é bem conhecida a especial riqueza e dificuldade dos diálogos cerimoniais, que não posso dizer que eu seja capaz de realmente compreender - e certamente uma vida toda com eles não me permitiria chegar a fazer. O que segue se baseia numa íntima convivência ao longo de 10 anos, totalizando algo como 7 anos de andanças, conversas, dificuldades e alegrias com o que gosto de chamar de parentes. Uma vida marcada pela morte, como tentarei mostrar.

Pois minha convivência com os Yanomami ensinou-me que a morte constitui o ponto de vista privilegiado para entendê-los: é ela e tudo o que the está relacionado que dá sentido e estrutura a vida yanomami. O ritual funerário - reahu, ou xaponomou entre os sanumá - é o grande exemplo disso. Trata-se do maior evento, a partir do qual, toda a rede de relações sociais (de cooperação e aliança, mas também de oposição e hostilidade) das comunidades envolvidas é atualizada. Creio também que a importância da morte entre os Yanomami transparece nos temas preponderantes das etnografias sobre eles: a guerra, a doença etc. 
Eu mesmo não tinha, de início, nenhum interesse maior pelo assunto; a tanatologia nunca me interessou sobremaneira. Mas encontrei-me numa situação que me fazia pensar na de Evans-Pritchard entre os Nuer, interessado em formas políticas e levado, constantemente, a falar de gado.

"Most of their social activities concern cattle and cherchez la vache is the best advice that can be given to those who desire to understand Nuer behaviour" (1977 [1940]:16),

observa ele. No nosso caso, seria possível substituir "gado/vaca" por "morte" e todo o resto se aplicaria. De modo que eu também fui levado a um tema que, de início, não constava de minhas inquitetações etnográficas, por assim dizer, e se algum conselho me coubesse dar aos que buscam entender os Yanomami, numa paráfrase de Evans-Pritchard, diria: cherchez la mort. Com bastante tato e discrição, certamente.

A presente tese está estruturada como segue. Nesta introdução, busco lembrar alguns aspectos gerais dos que chamamos Yanomami, comento minha experiência de campo e a razão de ser do tema central da tese.

No primeiro capítulo, a partir do idioma do parentesco, descrevo as categorias sócio-políticas que servem de referente nas relações com o outro e com exterior. Tomando como centro ou ponto de partida o grupo local - espaço da identidade e da solidariedade -, os Yanomami estabelecem uma escala em que, quanto mais nos afastamos da aldeia, mais as relações são marcadas pela alteridade e conflito. Vemos que é através das mortes, decorrentes dos enfrentamentos entre aldeias inimigas, que a máquina ritual-escatológica se põe em marcha: é então que o grupo se refaz, que as as comunidades envolvidas se mobilizam, que as alianças são 
atualizadas, enfim, que o grupo ao mesmo tempo se constitui e se abre para o exterior.

No segundo capítulo, visitamos a ontologia yanomami, para quem o cosmo é povoado por uma infinidade de imagens, que são responsáveis pela natureza dos seres e coisas e pelo equilíbrio do mundo e da vida tal como se apresentam. O seu xamanismo pode ser descrito como a manipulação dessas imagens, que são chamadas de hekura. Veremos que esta categoria de ser constitui, na verdade, uma espécie de curto-circuito ontológico na metafísica yanomami. Estão situados na interseção da animalidade e da humanidade (yanomami).

No terceiro capítulo, proponho uma síntese das reflexões sobre a morte na etnologia sul-americana. A construção simbólica (sócio-cósmica) da morte tem, com efeito, se apresentado como uma porta de entrada para a grande arena metafísica onde a pessoa ameríndia é criada, construída, destruída, devorada, eternizada, como demonstram os trabalhos hoje clássicos de Carneiro da Cunha (1978) e Viveiros de Castro (1986).

No capítulo quarto, descrevo o reahu, ritual mortuário que poderia ser apelidado de "kula (ou potlatch) dos Yanomami": "fato social total" (cf. Mauss 1993 [1928]:147) em que se exprimem os mais vários aspectos da cosmologia e da vida social yanomami.

No quinto e último capítulo, o discurso yanomami sobre a morte permite abordar o tema da construção/desconstrução da pessoa humana e mostrar que a natureza plural da pessoa a aproxima muito mais da idéia de divíduo (cf. Strathern 1988) do que da de indivíduo. Além disso, veremos que o duplo da pessoa yanomami prende seu destino ao de seus inimigos, para quem se apresenta sob a natureza de uma presa a ser caçada.

Faço, então, algumas considerações finais a partir do exposto, retomando teorias da guerra nas terras baixas sul-americanas para, finalmente, encontrar na Grécia clássica - graças a Jean-Pierre Vernant - alguns caminhos para compreender a relação entre os Yanomami e a morte. 


\section{Capítulo I - Entre si... com os outros e contra os outros}

omecemos por uma questão que tem-se colocado com cada vez mais força

para a etnologia, especialmente nas Terras Baixas da América do Sul, e que já foi mencionada na Introdução, a saber, a das unidades sociais. O que é (se é que existe, cf. Wagner 1974) um grupo (social) nesse caso?

Por todos os lugares onde andei, a estrutura social elementar das aldeias yanomami era mais ou menos aquela dos Fenàmat'eri descrita por Judith Shapiro (1972:72), ou seja, dois grupos de irmãos, ou primos paralelos, casados com as irmãs um do outro. Isso é verdade para as comunidades de pequenas dimensões em torno de vinte habitantes -, tanto como os Parawauteri e os Koherepiweiteri, na região do Alto Demini no Amazonas, por exemplo, como para tantas outras na Serra Parima, em Roraima. Mesmo para comunidades maiores, com cerca de uma centena de membros, o modelo era muitas vezes aplicável, constituindo a base sobre a qual todo o resto se agregava.

É preciso salientar, no entanto, que esse talvez não fosse o caso no passado, antes de as epidemias dizimarem as populações, quando as comunidades tinham uma dimensão bem maior, somando algumas centenas de pessoas por aldeia, e onde várias parentelas coexistiam. Mas tal nos parece ser o contingente demográfico mínimo sobre a qual pode-se estabelecer uma aldeia yanomami tendo chances de perpetuar-se; aquém dela, seria melhor se agregar a uma aldeia maior.

Dentro de uma perspectiva lévi-straussiana, poderíamos dizer que o limiar de que falamos é a possibilidade da troca. Como nos reduzidos grupos nambikwara com que conviveu Lévi-Strauss, o conjunto de cunhados seria a "sociedade reduzida a sua mais simples expressão" (Lévi-Strauss 1955:365). Aquém desse limiar, os Yanomami não poderiam erguer sua rede de parentesco e de alianças, tecida sobre o casamento com a prima cruzada bilateral - o que implica dois homens, ou dois 
grupos de homens, trocando suas irmãs e a perpetuação das trocas nas gerações subseqüentes.

Os Yanomami não parecem compartilhar nossas dificuldades teóricas quando se trata de definir grupos e a pertença a eles. Como já mencionei, um yanomami se define face a outro declarando sua pertença a uma comunidade, o que se expressa pelo nome da aldeia (geralmente uma referência ao sítio escolhido para a lavoura) acrescentando-se o sufixo -teri ou -theri. Os Koriyauopëtheri, por exemplo, são os membros da aldeia situada em Koriyauopë - lugar onde há ninhos de aves kori suspensos. É que no sítio onde essa comunidade abriu uma nova roça e para onde se mudou mais tarde, havia uma grande árvore de onde pendiam os ninhos de kori (Psarocolius decumanus, também denominada kanaporomi), pássaros que constróem seus ninhos suspensos nos galhos das altas árvores. Se perguntarmos a alguém desta aldeia o que ele é - em yanomami, a pergunta seria, literalmente, "que tipo de habitante/gente você é?" [weti teri kë wamaki / weti theri wamaki?], o que se traduz por "de que aldeia você é" ou ainda por "a que comunidade pertence?"7 —, a resposta será "sou koriyauopëtheri!". Até 2002 aproximadamente, os membros desse mesmo grupo responderiam à mesma pergunta de outro modo, dizendo-se pirisiteri ("gente da savana/pirisi/"). A mudança de nome, no caso, pode ser atribuída à morte de José, o ancião mais respeitado do grupo, como um meio de esquecer esse evento especialmente significativo. Outros grupos mantêm o mesmo nome, apesar das mudanças de aldeia, como é o caso dos weyokiweiteri. Seja como for, todo yanomami se define em relação ao pertencimento a um coletivo discreto, um nós.

No universo das Guianas, Rivière (1984 [2001] :37) considera que, apesar de sua existência efêmera, a aldeia - ou os seus moradores -, é o mais próximo que conseguimos chegar de algo que se aproxime de um grupo social com uma

\footnotetext{
${ }^{7}$ Gostaria de ressaltar que esta é uma questão importante para os Yanomami e invariavelmente freqüente quando o contexto reúne membros de várias aldeias desconhecidas entre si, como é o caso de reuniões patrocinadas por órgãos do governo ou por entidades não-governamentais. Estamos assim longe das questões de filiações grupais malencontrosamente criadas pela etnologia social do século passado, como critica ainda Howard (1993:231) em seu artigo sobre os Waiwai e que eram ridicularizadas pelos interlocutores ameríndios: "As perguntas do tipo: 'A que tribo você pertence?' eram respondidas com risadas, piadas, declarações de ignorância, ou respostas que variavam conforme a ocasião".
} 
existência corporativa. Conclui também que no estudo de sua formação, composição e dispersão podemos vislumbrar quais princípios articulam a própria estrutura social. Howard (1993:230-31) critica Rivière pelo que Ihe parece ser visão atomística de grupo, talvez corolário de um modelo substantivista de sociedade. Também considero, como a autora, que é no domínio das relações entre os grupos que se encontra o material mais rico e revelador das sociedades guianenses. Ponto de vista, aliás, partilhado pelos pesquisadores membros de pesquisa temática dedicada à análise comparativa de sociedades guianenses (realizada no NHII-USP), conforme esclarece Denise Grupioni (in Gallois 2005:41):

"[U]m dos objetivos da Pesquisa Temática 'Sociedades indígenas e suas fronteiras na região Sudeste das Guianas' vem sendo o de questionar o foco - localista - e o produto - fechamento sociocosmológico, buscando desvendar o que se revela quando se parte da análise das redes multilocais que se configuram na região".

Aproximando-me também das conclusões dessa equipe, tampouco creio que a aldeia, ou este sujeito coletivo, ou grupo-sujeito ${ }^{8}$ (Stolze 2005:114), que compõem seus habitantes, seja tão efêmero quanto afirma Rivière. Como nos casos guianenses iluminados - mais particularmente o dos Tiryió - por Grupioni (idem:23-51), é possível perceber, entre os Yanomami, a existência de grupos com considerável profundidade genealógica. Na verdade, se podemos falar de algo que atravessa as gerações yanomami, trata-se bem da história de sua aldeia, ou, em outros termos, da memória da trajetória percorrida pela comunidade na ocupação sucessiva de seus diversos sítios através do tempo. $O$ relato desse percurso pode

\footnotetext{
${ }^{8}$ A respeito disso, Tânia S. Lima, refletindo sobre o conceito de grupo-sujeito proposto por Guattari, diz o seguinte: "o autor (Guattari 1987) propôs uma distinção entre grupos-sujeito e grupo assujeitado, pretendendo designar não duas espécies de grupos, dois grupos sociais, mas dois estados ou pólos do grupo - para o qual o assujeitamento é um risco sempre presente em seu horizonte. "Os grupos-sujeito, afirmava, se constituem nas adjacências de um socius, do qual se destacam (...). A intenção principal do conceito voltava-se, assim, para estados de grupos que nem podem ser descritos e/ou vividos como ausência de hierarquia, e como ausência de poder, nem vêm a constituir uma verticalidade hierarquizante, notável em seus estados de assujeitamento (...) $O$ grupo-sujeito "detém o poder real", mas o sujeito "nunca é dado de uma vez por todas (ibidem, p.98). Era para a forma em que a intervenção do sujeito se efetuava no grupo, para o modo em que este atuava como a coordenada ou o eixo do grupo que se dirigia o autor. $E$ sugeriu que o problema envolvia "coeficientes de transversalidade". Esta, disse ele, "só pode ser posta em relevo [naqueles] grupos que, deliberadamente ou não, tentam assumir o sentido de sua práxis e se instaurar como grupo-sujeito, colocando-se assim na postura de se assumir como agente de sua própria morte" (ibidem:101; ver também Deleuze, 1974:i-xi)" (Lima 2005:114).
} 
ter a profundidade de bem mais que um século, remontando a várias gerações anteriores, e atravessar regiões bem longínquas: às vezes, a várias dezenas de quilômetros uma da outra.

Para Albert, essa cadeia histórica de topônimos é o que constitui, na verdade, o suporte da memória social yanomami:

'Cet 'arbre toponymique' enregistre en fait toutes les trajectoires migratoires des groupes locaux issus d'un même 'bloc de population'. Tous les anciens en connaissent parfaitement les moindres détails et s'y réfèrent souvent dans leurs harangues nocturness ou matinales (...) à l'usage des plus jeunes. (...) Tout ce qui a trait à l'histoire collective (guerres, épidémies, alliances, contacts...) et à l'histoire individuelle (naissance, puberté, mariage, maladie...) se trouve ainsi chez les Yanomamë cristallisé sur cette structure toponymique" (1985:126)

Diversos relatos desse tipo me foram feitos sempre que eu pedia, com evidente empolgação. Sempre tive a impressão de que se tratasse mesmo de um gênero do discurso yanomami e, como todos os outros, atributo essencialmente masculino. Sua estrutura é invariavelmente idêntica e quase monótona: "Antigamente, meus antepassados, habitavam tal região. No entanto, desavenças com yanomami da aldeia tal, que acabaram provocando um conflito, os fizeram abandonar este sítio e abrir roça na região tal. Em seguida..."

Vale a pena ressaltar que quase sempre são as roças que dão nome aos sítios ocupados, como no caso dos Koriyauopëtheri citado acima. A trajetória de um grupo através do espaço é marcada, portanto, por pontos significativos - que são os sítios cultivados. Seu abandono aparece sempre como uma grande catástrofe. Aliás, normalmente, a mudança definitiva de uma comunidade para um outro sítio só se dá depois que uma nova roça aberta no novo local já está produzindo (cf. Albert 1985:19-20). A antiga só é definitivamente abandonada depois de sua completa exaustão e continua a ser visitada durante vários anos. No caso de conflito com inimigos poderosos, resultando no abandono da aldeia e das roças, a perda de suas roças implica para a comunidade também a perda de sua autonomia econômica até que novas roças sejam abertas e se tornem produtivas - o que tem um custo político considerável, como ressalta Chagnon: 
"Por duas ocasiões, na recente história do grupo de Koabawä, eles tiveram que abandonar seus jardins, fugindo de inimigos poderosos, e foram obrigados a se refugiar na aldeia de um aliado. Em cada uma das vezes, o grupo permaneceu com o aliado durante um ano ou mais, indo embora somente quando suas roças começaram a produzir. Em ambos os casos, os anfitriões pediram e receberam um número de mulheres do grupo de Kaobawä sem nenhuma espécie de reciprocidade, uma prerrogativa que exerceram por sua posição de força temporária" (Chagnon 1997 [1968] :159-160).

É por isso comum que uma comunidade disponha de duas ou mesmo de várias roças. Nos relatos yanomami de suas migrações, invariavelmente, a abertura ou o abandono das roças, ao lado dos combates e escaramuças contra outros grupos, aparecem de forma recorrente como os únicos referenciais históricos e geográficos da trajetória de cada comunidade:

"Ihi tëhë, yama tëka pëprarei kurorei.. 9."

"Abrimos então uma roça...",

assim começa sempre um novo capítulo da história da comunidade. Nunca é demais lembrar que, na maioria dos casos, é o nome atribuído à roça, acrescentando-se o termo teri ou theri (habitante, a gente, o povo de...) que portará a comunidade; a identidade do grupo estando assim estreitamente ligada à própria roça. Como dissemos, o nome é escolhido mais ou menos ao acaso segundo as características particulares do terreno, a abundância de certas espécies animais ou vegetais, ou ainda fazendo referência a um incidente ou fato inusitado que marcou a limpeza do terreno.

O protagonista dessa história é a comunidade e o motor, sem exceção, o conflito com yanomami de outras aldeias - pelo menos, esta é a maneira como os yanomami invariavelmente a interpretam. No relato, os enfrentamentos são muitas vezes atribuídos a querelas a respeito de mulher e, com menor freqüência, a uma disputa sobre a posse de cães de caça; aparecem ainda, porém mais raramente, as

\footnotetext{
${ }^{9}$ Ao longo de todo este trabalho, transcreverei - em nota de rodapé no caso de textos mais longos - as falas originais, gravadas em mini-cassetes. A tradução em português procura acompanhar o mais fielmente possível o original, embora a riqueza própria da língua yanomami seja muitas vezes sacrificada em nome da inteligibilidade do texto para um leitor lusófono. Os textos originais permitirão aos leitores familiarizados com a língua yanomami recuperá-la e, eventualmente, sugerir melhores soluções de tradução.
} 
acusações de feitiçaria ${ }^{10}$. Reproduzo aqui o que me foi contado em 2003 pelo velho Esmeraldo, da aldeia de Arokofithë-u, na Serra Parima, pois o considero bem representativo de muitos outros que sempre ouvi por onde andei:

"Os meus antepassados moraram em Yoporoo. Era lá que moravam antigamente, em Yoporoo. No entanto, surgiram desavenças com outros yanomami, o que acabou provocando um longo conflito com intermináveis enfrentamentos. Por fim, os meus fugiram de lá e se instalaram em Parimatha. A verdadeira terra dos meus antepassados foi Hwarimatha, próximo de onde hoje habitam os Moxahitheri, é lá realmente a terra dos meus: onde caçavam pacas, onde lavraram a terra... É lá a terra de meus antepassados, onde moram atualmente os Moxahitheri.

Batizaram essa terra de Serra da Korirotha, Koriroo... Isto mesmo: a denomiaram Koriroo. Mas então, novos e intermináveis conflitos surgiram e eles novamente se afastaram. Os antepassados dos Parafuri os atacaram, os flecharam e acabaram por fazer com que se retirassem de lá; novamente eles fugiram rio acima.

Reuniram-se em Parikiwë, onde passaram a morar. No entanto, mais uma vez, a tranqüilidade não durou muito: novamente, eles e os antepassados dos Parafuri se enfretaram. Muitos morreram de ambos os lados. Como acontecera anteriormente, meus antepassados tiveram que se afastar e se estabeleceram em Tihi-u.

Foi então que em outras paragens surgiram novos conflitos; desta vez, com os Xamathari. Estes atacaram os meus com feitiço, envenenando-os. Dizimaram os nossos; quase acabaram com eles! Minha gente não conhecia venenos e ficara desorientada. Revidara, no entanto, com flechas. Os meus flecharam os Xamathari em contrapartida. Tiveram novamente que deixar o sítio e esconder-se; por fim, afastaram-se de lá, indo até Toxopëtha, onde se estabeleceram em seguida.

No entanto, os antepassados dos Parafuri e os Xamathari reuniramse para atacá-los e mais uma vez houve enfrentamentos. Os meus estavam em desvantagem e a situação desfavorável obrigou-os a retroceder; tiveram que refazer em sentido inverso o caminho que

10 Outro tema também presente nos relatos é a hecatombe produzida pelas epidemias, principalmente a de sarampo - denominadas xawara pelos Yanomami - que varreram o território yanomami em meados do século XX. Escutei várias vezes a história da mortandade que reduziu aldeias inteiras a um punhado de pessoas. "A epidemia dizimou a gente... ficamos desorientados", contou-me, por exemplo, Atabaya, hukoweiteri, em 1996. 
haviam percorrido anteriormente. Estabeleceram-se então em Koamai-u, onde novos enfrentamentos ocorreram ....11

Vale lembrar que o tabu que cerca o nome dos mortos e, além disso, o profundo desrespeito que representa o fato mesmo de lembrar a existência passada de entes próximos que já morreram (o que pode redundar até mesmo em agressão física) impedem a adoção de um ponto de vista pessoal, como o adotado por Helena Vallero em seu relato colhido pelo médico e etnógrafo italiano Ettore Biocca (1968) na segunda metade do século XX. O relato dessa "mulher brasileira raptada pelos índios" é, portanto, único inclusive naquilo em que se afasta das formas narrativas dos próprios Yanomami. Nos relatos feitos por eles, jamais é adotado o ponto de vista de alguém ou de uma família em particular - trata-se sempre da comunidade, da aldeia.

Em todas as narrativas, é sempre a morte que faz com que as comunidades abandonem uma região e se desloquem para mais longe, tornando-se assim senão o "motor de sua história" ao menos o da trajetória através dos espaços da floresta, pois a história sempre é contada de tal modo que os deslocamentos só fazem sentido se entendidos à luz dos enfrentamentos armados contra yanomami de outras aldeias.

\footnotetext{
${ }^{11}$ Yoporoo hami, ipa pata thë hapa pirioma. Thë pë hapa pirioma kihami, Yoporoo hami, pata thë pë hapa pirioma yaro, ĩhi tëhë, hõximi kuprarioma, thë hõximi kuprarioma. Hõximi ha kuprarini, pë niayou xi wãriprou tëhë, niayou tëhë, niayou tëhë, waiha, pë tokurayoma. Ipa pata thë pë tokurayoma; thë pë ha tokurini, Parimatha ha pë piria kõkema, Parimatha ha.

Ipa pata thë pë urihi pë yai kua Hwarimatha pë, kihami, Moxaa hi thë ka kurehami, Moxahitheri pë ka pirireha, ז̃ha, ipa pata thë pë yai urihi pë kua.

Amotha a xëiwehei, pë kĩaiwei, t̃ha pë urihipë yai kua. Awei thë ha kuikini, urihi wãaha hiramahe. Korirotha ki hiramahe, Koriroo thë, awei! Koriroo thë ãha hiraihe; hirakiheni, f̃hi tëhë, pë niayou yauapraroma kõkuheni; pë kasia kõprarioma. Parafuri pë xë, parafuri pëni pata xë, parafuri pëni pata xë, pë ha niayoni... pë niayou, ipa pë në pata yaxupramahe; pë tokua yamoa kõrayoma.

Parikiwëha pë piria ha kõikini, ĩha pë piria kõa tëhë, pë totihi pirio kõonimi: niayou xoaoma. Niayou ha xoaikini, parafuri pë patani, ṙhi parafuri pë patani, ipa thë pë pata niai xoaomahe. Niamahe. Îhi niaihe tëhë, kama pë nomamai hetuohe, nomai yauaprarouhe; yauaprarouhe, pë kasia kõprarioma. İhi pë kasia ha kõpraruni, Tihi uha, Tihi uha, pë piria kõkema.

Pë ha piriikini, îhi tëhë, ai xomi waitheri, ai xomi yo hami, waitheri thë pë kua kõprarioma, xamathari pë. Awei, xamathari pë waitheri kua kõprarioma; waitheri kua ha kõprarini, ipa pë horamahe; horamaheni, hwëri kikini. Awei! Pë horamahe, pë maamamahe. İhi maamai, kama pëni! Ipa pëni patani hwëri kiki tanimihe. Kiki taimi yarohe pë pihi hëtëmou yaro, xarakani, xamathari pë niai no hoomahe. Pë niai no hoowehei, r̃ha pë hria ha kõprarini, kihi ĩhi thë hõya ha kõriheni kasia kõprarini, Toxopëtha ha, Toxopëtha ha pë piria kõkema, Toxopëtha ha.

Ĩhi pë piria kõkeiwei, ĩha pë niai xoaomahe; t̃hi parafuri pëni patani xamathari pëni patani niai hetutuhe; hetutu yarohe, totihiproimi yaro, pë yatotoa kõprarioma. Pë yatotoa kõprariowei, Kõamai ha, Kõamai-u ha, pë piria kõkema. Ĩhi pë piria kõkema makii, pë niai kõo xoaomahe.
} 
Essa dinâmica - conflito-fuga - novo conflito - novo deslocamento - pode inclusive ser apontada como responsável pela formidável expansão territorial levada a termo pelos Yanomami nos últimos dois séculos, cujo território teve sua superfície multiplicada por 16 vezes (Ramirez 1994:17)! Desde o fim do século VIII e início do XIX, partindo da região entre o Ocamo, na Venezuela, e a Serra Parima, no Brasil, os Yanomami ocuparam, a leste, os vales dos rios Uraricoera, Mucajaí e Catrimani; a oeste, os vale do Demini, Padauiri, do Marauiá e as cabeceiras do Cauaburi, no Brasil. Na Venezuela, estenderam seu território até o vale do Erebato, a norte, e ocuparam o vale do Siapa até o canal Cassiquiare, a oeste ${ }^{12}$. E isto acontecia justamente na contra-mão da história amazônica, que então registrava o desaparecimento dos outros grupos indígenas.

A impressão que se tem, ao ouvir tais relatos, é a de tratar-se de uma fuga a palavra tokt, "fuga", ressurge constantemente - que nos parece interminável, em uma odisséia de nós contra os outros. O sentido de permanência e continuidade da comunidade, porém, é outro aspecto notável dessas histórias - apesar das cisões, das mudanças geográficas, de nome, de composição, o grupo (-teri) permanece como o único suporte referencial estável através do tempo. O que afastaria, assim, a possibilidade de considerar o grupo como caracteristicamente efêmero (Riviere 1991); mais do que isso, parece ser um elemento fundamental a conformar todas as relações com os outros, com o exterior; ou seja, aquelas marcadas pelo signo da alteridade.

Precisamos, pois, entender os mecanismos internos que lhe dão sustentação e conformam esse grupo-sujeito que é a aldeia yanomami. "Em uma aldeia ideal",

\footnotetext{
12 Uma tal expansão não poderia acontecer sem o crescimento demográfico que a acompanhou e possibilitou. Supõe-se que eles tenham dobrado ou mesmo quadruplicado seu número (Colchester 1985:29). Lizot (1984:186-187), falando dos Yanomami "centrais", calcula que as comunidades atuais provenientes de duas aldeias originais, Husirawë e Irabraobë, tiveram seu número de habitantes multiplicado por cinco na primeira metade do século XX. Em 1900, Husirawë e Irabraobë contavam, de acordo com Lizot, 150 e 250 pessoas respectivamente. Setenta e quatro anos depois, a população era de 2.068 pessoas e o número de aldeias subiu de dois para 35 . A expansão terminada, o território yanomami estava assim distribuído entre os subgrupos: os Yanomami ocidentais, com uma população de 11.752 pessoas, ocupavam uma superfície de $78.871 \mathrm{~km}^{2}$; os Yanomami orientais, 5.311 pessoas, $40.630 \mathrm{~km}^{2}$; os Sanuma, 3.262 pessoas, $43.916 \mathrm{~km}^{2}$; e finalmente os 856 ninam ocupando um território de $28.681 \mathrm{~km}^{2}$ (Colchester 1985:7).
} 
afirmou Rivière para o universo das Guianas (2001:102 n. 5), "a afinidade não existe". A idéia, ou o ideal, segundo o autor, é criar um paraíso consangüíneo, tal qual o "céu" dos Xavante que seria um espaço sem afins (idem). Falar em "céu", em relação a cosmologias ameríndias, certamente mais nos afasta do que nos aproxima de sua compreensão. De todo modo, no mundo dos mortos krahô tampouco haveria afins (Carneiro da Cunha 1978:122), mas isso não significa que esse possa ser considerado um "ideal". Certemente não um "ideal" para os vivos. Pois o mundo dos mortos é, como bem mostra Carneiro da Cunha (1978), um anti-mundo, por assim dizer, uma anti-sociedade. Inviáveis, os mundos ao avesso que são os mundos dos mortos podem ser concebidos como de pura consangüinidade, como entre os Xavante e os Krahô, ou como de plena afinidade, o que parece ser o caso entre os Yanomami. De um ponto de vista lógico, não há diferença: é como se eles nos reafirmassem, nas concepções escatológicas, a inviabilidade de uma sociedade sem consangüíneos $\underline{e}$ afins (uma sociedade sem troca). E se Hapóro, citado por Carneiro da Cunha (1978:146), lembra que "estar vivo é bom", no caso yanomami, se de ideal de vida se pode falar, esse seria a própria aldeia, pensada sempre, tanto no dia-adia quanto nos relatos míticos, como um porto seguro em um mar cheio de perigos que é a selva.

A aldeia yanomami geralmente é formada por uma grande casa comunal (xapono ou yano) em forma circular, contando com um espaço vazio no centro, em torno do qual cada família dispõe de seu próprio espaço, onde dorme e cozinha. O exterior desmatado é tomado por um emaranhado de plantas e detritos que se acumulam com o passar do tempo. Na maioria dos casos, as roças se situam a alguns minutos de caminhada da aldeia.

Lembremos, primeiramente, do ponto de vista do parentesco, as relações que a conformam. Mas, antes de continuar, sublinharei algumas características e os princípios gerais do sistema de parentesco yanomami, detalhadamente descrito por Albert (1985:221-235) e Lizot (1984), entre outros. Sua terminologia é do tipo dravidiano, os primos paralelos sendo classificados como co-irmãos e diferenciados dos primos cruzados. Esses últimos são chamados pelos mesmos termos que designam esposa e esposo (hearõpi et hesiyopi; $\mathrm{FZD}=\mathrm{MBD}=\mathrm{W}, \mathrm{WBW}=\mathrm{Z}$ ). Bifurcações similares são encontradas no primeiro nível das gerações ascendentes e descendentes. Assim, na geração ascendente, encontramos duas categorias: de 


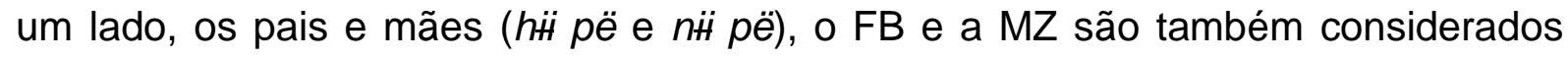
como tais; e, de outro, os colaterais cruzados, o MB e a FZ (ẍ̈ pë e yesiwë pë), designados como sogro $(\mathrm{MB}=\mathrm{WF}=\mathrm{HF})$ e sogra $(\mathrm{FZ}=\mathrm{WM}=\mathrm{FW})$. Essas duas classes de parentes, como lembra Lizot, não se opõem unicamente como os da linha direta e os da linha colateral, "mas também, e sobretudo, como consangüíneos e aliados." (Lizot 1984:101) Ora, o casamento prescrito com a FZD e a MBD - a troca simétrica de irmãs - age de maneira que a linha colateral seja verdadeiramente percebida como se situando na categoria de afins.

Remontando duas gerações $(g+2)$, a distinção entre afins e consangüíneos desaparece; os avós (lineares) são chamados pelo mesmo termo que designa sogro e sogra (colaterais cruzados, x艹̈ pë e yesiwë pë) ${ }^{13}$. A consangüinidade perde terreno ainda na geração mais alta $(g+3)$; os bisavós são classificados como primoscunhados/primas-cunhadas (xori pë/natohi pë) e de primas-esposas/primos-esposos (hesiyopi pë/hearõpi pë) (Albert 1985:228). As mesmas equivalências são encontradas nas gerações descendentes; assim, os netos são designados como sobrinhos:

"assim, a avó e a irmã do pai são chamadas pelo mesmo termo, assim como o avô e o irmão da mãe; netos são classificados de um modo recíproco, como sobrinhos cruzados" (Shapiro 1972:72).

Como mostra Albert, a regra de equivalência poderia ser assim estabelecida: para os afins, há uma "abolição da distinção entre gerações adjacentes": $g+1=g+2$, g-2 = g-1; para os consangüíneos, a abolição da cosangüinidade a partir das gerações centrais $(g-1, g 0, g+1)$ assim como uma inversão de gerações: lineares de $g+2=$ colaterais cruzados de $g+1$, lineares de $g-2=$ colaterais cruzados de $g-1$. Finalmente, nas gerações extremas, os bisnetos e os bisavós equivalem a afins do mesmo nível de Ego: g+3 et g-3=g0 (Albert 1985:228) ${ }^{14}$.

\footnotetext{
${ }^{13}$ Percebi que curiosamente na Serra Parima, em Roraima, há uma inflexão dessa regra: o avô é denominado pelo mesmo termo que o utilizado para o germano mais velho do mesmo sexo, aiwë; $O$ mesmo não ocorre com a avó, contudo, que continua a ser denominada yesi, ou seja, como a tia patrilinear/sogra.

${ }^{14}$ O que contraria a afirmação de Lizot (1984:94-97) de que a terminologia só é operatória nas gerações centrais (G1, G0, et $\mathrm{G}-1$ ), permanecendo confusa e imprecisa nas gerações extremas (G2 et G-2). A confusão talvez se deva ao pouco conhecimento da língua yanomami que tinha Lizot quando elaborou seu artigo sobre o vocabulário do parentesco - publicado pela primeira vez em 1971
} 
Lizot, que partia quase que exclusivamente dos estudos realizados por Chagnon, afirma (1984) não estar certo de que os avós sejam chamados de xoayë (meu sogro/irmão de minha mãe). Ora, não somente pode-se chamá-los assim, como também é justamente desse modo que são designadas todas as gerações de ancestrais, quando nos referimos a elas de uma maneira geral. Assim, para indicar seus antepassados efetivos, um yanomami irá referir-se a eles como xoayë pë, ou seja, como meus sogros ou meus colaterais cruzados, o que significa, na verdade, que os consagüíneos das gerações distantes - neste caso ascendentes, mas o mesmo também é verdade para os descendentes - são francamente afinizados; não havendo espaço para a consangüinidade na distância e no tempo longínquo - o que fundamentaria nossa afirmação anterior a respeito do mundo dos mortos yanomami, povoado quase que exclusivamente de afins - uma conseqüência lógica da nomenclatura de seu sistema.

Essa tendência a produzir aliados e a transformar os consangüíneos em afins é, ao nosso ver, uma das principais características do sistema yanomami de parentesco, como aliás já bem observou também Shapiro:

"De maneira geral, é apropriado dizer que a regra básica que governa a aplicação dos termos de parentesco yanomami é tal que quando uma alternativa existe, acentua-se a afinidade e elimina-se a consangüinidade." (Shapiro 1972:79)

Não é por nada que, na ausência de um laço de parentesco direto qualquer, é justamente o herimou, tratamento pelo termo designando os cunhados (xori, ama ou heri) - aliados por excelência - que se estabelece entre dois desconhecidos que acabaram de se conhecer. Teríamos então, entre os Yanomami, como já foi apontado por Viveiros de Castro (1993:174) mais um exemplo do englobamento, do ponto de vista mais amplo/exterior, da consangüinidade pela afinidade. No nível local, a oposição entre afins e consangüíneos não é de maneira nenhuma realçada até porque, como sugere Robin Fox, uma das características desse sistema consiste em que, em uma aldeia dada, todos os aliados de Ego sejam também seus parentes, "não se espera que seja acentuada a oposição entre 'aliados' e

e reunido mais tarde em Les Yanomami centraux (1984) -, tanto quanto à pobreza do material etnográfico disponível na época sobre os Yanomami. 
'consangüíneos"' (Fox 1967:240). E de fato, no nosso caso, não o é de maneira nenhuma. De certa forma, até porque, como já bem lembrou Stolze (2005:101), "os afins efetivos não conotam alteridade", ainda que as relações marcadas pela alteridade sejam remetidas ao registro da afinidade - ou seja, que uma relação inaugural seja sempre conformada pelo molde da afinidade, segundo bem já disse Shapiro (1972:18).

Voltemos ao sistema de parentesco em suas linhas gerais. Nas gerações centrais, duas categorias de parentes são claramente distinguidas, gerando o que Lizot (1984:101) chama de "dicotomia do universo de parentesco" yanomami, e considera como sua característica fundamental:

"A oposição entre linha colateral e linha direta aparece como secundária, enquanto a existente entre os cosangüíneos e os aliados parece governar tudo:

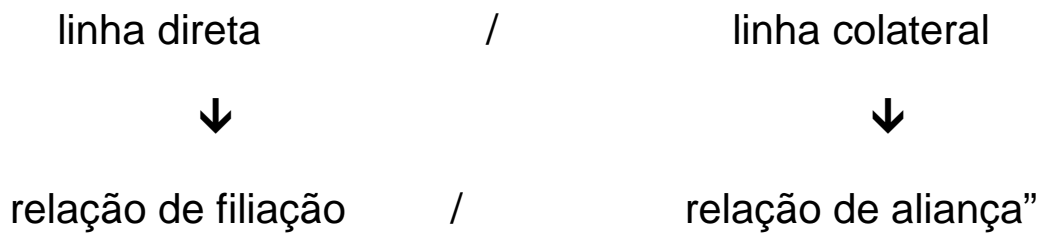

$\mathrm{Na}$ realidade, essa dicotomia está na base estrutural incontornável do sistema, fundado sobre a troca simétrica de irmãs, a partir da qual outras características, outros traços se juntam para dar-lhe uma arquitetura particular, especificamente yanomami.

Deve-se assinalar uma clara tendência à endogamia, os casamentos sendo realizados preferencialmente no interior da própria comunidade. A patrilocalidade é, por sua vez, contrabalançada pelo serviço da noiva - que dura sempre alguns anos - e por estratégias políticas, que, às vezes, fazem em sorte que a uxorilocalidade seja mais vantajosa para o marido ou que obrigam-no a abandonar sua comunidade pela de seu sogro. Viveiros de Castro (1995:12) nos lembra a existência, nos sistemas dravidianos da Amazônia de um "atrator uxorilocal de base, infletindo um campo estratégico onde o peso político das parentelas é o fator decisivo". 
Finalmente, os laços patrilineares parecem ter, entre os Yanomami, um peso maior, como lembra Shapiro:

"existe - dentro da classificação bilateral [...] - uma clara tendência para valorizar laços de parentesco na direção patrilinear; em outras palavras, esquecimentos genealógicos parecem operar mais no caso de relações entre mulheres, enquanto laços traçados entre homens são relembrados mais atenciosamente" (Shapiro 1972:81).

Um outro índice a respeito de aldeia/comunidade servir de referência sóciosimbólica da identidade é o uso do pronome inclusivo pëmaki, $2^{\underline{a}}$ pessoa do plural inclusiva, utilizado principalmente entre os Yanomami ocidentais. Certamente, seu emprego, como o de todos os pronomes, depende do contexto e é relativa ao englobamento ou não do(s) interlocutor(es) ao nós - no caso contrário utiliza-se o pronome yamaki. Entretanto, notei que a utilização do pronome pëmaki em discursos e pronunciamentos públicos sempre se dava quando o auditório se reduzia aos próprios membros da aldeia; ou seja, o limite do nós inclusivo se situa nos muros da própria aldeia, ou melhor dizendo, nas paredes do xapono.

Assim, podemos desde já tirar algumas conclusões. A primeira é a de que a aldeia é um dos nós - tanto no sentido de uma identidade coletiva quanto no de "nó" de uma rede de relações que inclui essa "unidade" e a configura (cf. Perrone-Moisés [org.] 2006) - talvez mesmo o mais importante nó da rede de relações que compõem o tecido social yanomami. Assim, no contexto de relações entre indivíduos e grupos yanomami, a referência, o ponto de partida, é sempre essa comunidade (de origem) e jamais a parentela imediata, ou um um grupo qualquer de comunidades, formado ad hoc ao sabor da conjuntura e das estratégias de aliança e isolamento dos inimigos, por exemplo. A pertinência a tais grupos se sobrepõe, na verdade, a tais formações (essas efêmeras) geradas em contextos de conflitos específicos. Raríssimas vezes testemunhei casos em que alguém de uma aldeia envolvida em um conflito com outra pudesse manter-se neutro, mesmo havendo laços de parentesco efetivo com membros do grupo adversário ${ }^{15}$. Os sujeitos das relações

\footnotetext{
${ }^{15}$ Quando isso acontece, trata-se sempre de mulheres de idade que têm laços de parentesco em ambas aldeias. Em alguns casos, elas desfrutam de uma espécie de salvo-conduto, de imunidade que Ihes permite transitar sem riscos - ou quase - entre as comunidades em conflito. Na primavea de 2005, envolvido nas negocições de paz entre os Yanomami do platô de Surucucu e os grupos que habitavam às margens do rio Awei-u (Melo Nunes), tive a oportunidade de testemunhar tal fato. Ao
} 
políticas são sempre essas comunidades que chamo "de origem", e jamais algo parecido com clãs ou linhagens, que, até onde se sabe, inexistem entre os Yanomami ocidentais e orientais ${ }^{16}$.

Isto não quer dizer de maneira nenhuma que as relações yanomami se limitem aos contornos da aldeia/casa comunal, que o que conecta tais grupos ao mundo circundante tenha pouca ou nenhuma importância. Ainda menos que estas mesmas relações possam ser explicadas por uma reflexão que tome um universo de análise se esgotando nos limites da própria aldeia. Na realidade, é o contrário que se passa: para se compreender as relações existentes no interior de uma dada aldeia é necessário alargar o universo de pesquisa para o que Albert denominou de conjunto multicomunitário (1985), ou seja, tanto para o conjunto de comunidades que se inter-relacionam de uma maneira amistosa quanto para as que estão no campo oposto, da inimizade. As primeiras partilham uma história e uma origem comum com a aldeia em questão; são sempre oriundas de uma mesma comunidade de origem em um processo de fissões sucessivas.

Albert (1985:108ss) distingue no interior do que chama de "etnia" yanomami, de um lado "des sous-ensembles de communautés liées par des relations historicodémographiques" e, do outro, "des sous-ensembles de communautés associées par des relations matrimoniales synchroniques". Os primeiros corresponderiam, segundo Albert (1985:109), ao que Chagnon chamara de "blocos de população"; equivalem

visitar a comunidade de Auwei-u para tratar justamente do assunto, acompanhou-me uma yanomami da aldeia Xirimifiki, envolvida em um sangrento conflito com a primeira há vários anos. A yanomami, esposa de um líder de Xirimifiki, era, no entanto, originária da comunidade de Auwei-u e não demonstrou nenhum constrangimento e nem encontrou nenhum problema ao visitar seus parentes, que a receberam carinhosamente.

${ }^{16}$ Embora Chagnon (1968) fale de clãs, quando parece referir-se, na verdade, a esses grupos com profundidade de várias gerações que as narrativas yanomami descrevem e que constituem a referência de auto-identificação. Tenho a impressão de que a perenidade destes grupos aparentados e sua corporalidade social é o que está em jogo quando Alcida Ramos (1990) fala da existência de linhagens entre os Sanima. Discutindo as categorias de identidade e alteridade entre os Sanumá, Ramos comenta os vários termos que se relacionam com a denominação das aldeias e ao mesmo tempo com a identificação de unidades de descendência. Argumenta ainda que as comunidades tomam o nome de uma das linhagens nela residentes: "o que gera mais um nível de contraste, a saber, o de linhagens dentro de uma mesma aldeia; por exemplo, kadimani dïbï e wanabïdili dïbï dentra da comunidade de Kadimani" (Ramos 1990:290). O que a autora chama comunidade de Kadimani parece corresponder ao que venho chamando de comunidade de origem - com uma origem comum no passado remoto - e as linhagens às aldeias ou grupos locais, como as existentes entre os Yanomami orientais e ocidentais. Para uma discussão acerca desse debate quanto à existência ou não de grupos de descendência unilinear entre os Yanomami, ver Albert 1985:111-121. 
certamente ao que aqui denomino "comunidades de origem", assim descritas por Albert (1985:108-109):

"la loi de composition de chaque sous-ensemble de groupes locaux considéré repose sur une relation de commune origine: les communautés qui s'y trouvent incluses sont toute issues, dans un passé évalué approximativement à 150 ans, et par fissions successives, d'une unité résidentielle unique"

A meu ver, é justamente esta procedência comum que faz com que os Yanomami se reconheçam como iguais; ou melhor: como fazendo parte de um entre-si. Referindo-se a outras comunidades aparentadas, dizem: kamiyë yamaki xĩro, "[fazem parte de] nós ainda", em uma tradução literal, ou seja, a categoria nós estende-se também a eles. Assim, segundo entendo, este nós não compreende as aldeias que, mesmo tidas de certa forma como aliadas ou com as quais se mantém um bom relacionamento através dos anos, não compartilham uma mesma origem comum.

Do Pateo, em seu notável trabalho de pesquisa sobre os grupos da Serra Parima, em Roraima, chega, no entanto, a outras conclusões a respeito das comunidades aparentadas pela mesma origem, que ele chama de "grupos endogâmicos de vizinhança". Para o nosso autor, essas unidades de natureza supralocal têm um caráter mais histórico do que estrutural, mantendo, assim,

"um quadro de relações em constante transformação, variando de um continuum que vai da amizade (...) ao antagonismo, geralmente levado às vias de fato mediante a realização de reides recíprocos" (Do Pateo 2005:104).

Concordo com Do Pateo quando afirma que as interações entre esses conjuntos supralocais podem variar segundo a conjuntura e os interesses de cada um, indo da amizade às hostilidades abertas. Discordo, entretanto, quando diz que a composição de tais grupos é alterada constantemente,

"seguindo o movimento das unidades residenciais que se deslocam por sua região devido a questões econômicas (...), ou políticas" (2005:107).

Ora, é exatamente o contrário que testemunhamos justamente na Serra Parima, onde, apesar de as comunidades se fixarem quase que de maneira permanente depois de décadas em um território relativamente pequeno, obrigando 
os grupos discretos a um relacionamento estreito, a pertença de cada uma delas a cada grupo nunca foi objeto de mudança ao sabor das alianças, já que é resultado de "relações genealógicas" estabelecidas entre os grupos locais de origem comum.

Até onde eu saiba, a pertença aos "nós" (kami yamaki) dessa rede é invariável: assim todos enumerarão da mesma forma as várias aldeias que compõem cada um dos "grupos endogâmicos de vizinhança" - tanto o "nós" singular quanto os outros (no plural) -, referindo-se, sempre que for o caso para dirimir dúvidas, à aldeia que deu origem às demais do grupo. O fato deste dispositivo "operar com fins essencialmente cognitivos", como assinala Albert (1985:123), "permitindo a cada grupo local de se situar em uma vasta rede multicomunitária por inclusão ou exclusão, referindo-se a outros subconjuntos" - mecanismo que também tive a oportunidade de ver em operação - em nada altera sua natureza de um encadeamento histórico determinado genealogicamente pela origem comum partilhada por cada um dos conjuntos.

Esse "senso de comunidade" se fortalece e se perpetua, a meu ver, também através de casamentos entre membros desse grupo de comunidades aparentadas que chamo de grupo de origem, ou, na expressão yanomami, os que "ainda fazem parte do nós/são ainda nós/continuam sendo nós". Quando não se casa dentro da própria aldeia - o que constitui a regra ${ }^{17}$ - é no âmbito dessas comunidades que se procura o parceiro. Raríssimamente alguém se aventura a realizar um casamento fora desse círculo; os riscos são tantos que fazê-lo seria um empreendimento por demais temerário - no mínimo, ser tratado como forasteiro em uma comunidade distante onde não se poderia contar com o apoio praticamente de ninguém diante das dificuldades inerentes à vida em outra aldeia que não a própria ${ }^{18}$. Na maioria das vezes em que soube de casamentos assim, eles pareciam muito mais instáveis do que os dois outros - entre membros da própria aldeia ou entre membros do mesmo grupo de aldeias aparentadas. Tais casamentos exogâmicos em termos da comunidade de origem se desfazem com freqüência, em geral dentro do período

\footnotetext{
17 Albert (1985:110) fala de uma "norme d'endogamie locale très explicite".

${ }^{18}$ Quando Albert (1985:110) se refere e uma proporção de "mariages inter-communautaires" bastante considerável, estaria, na verdade, se referindo a casamentos inter-aldeias pertencentes a uma mesma comunidade de origem e não para fora delas.
} 
inicial que corresponde ao serviço da noiva. Nos dois casos que conheci de casamentos duradouros entre pessoas de comunidades de origem diversas e atualmente inimigas (Xirimifiki e Awei-u), a tendência geral à uxorilocalidade (ainda que temporária $)^{19}$, foi invertida, vindo as mulheres a residir nas aldeias de seus maridos. O que não significa que tais casamentos sejam impossíveis.

As aldeias aparentadas que formam esse conjunto costumam ser próximas umas das outras, o que possibilita a seus membros visitar-se com uma certa freqüência e, até mesmo, em algumas ocasiões, realizar atividades coletivas mais ou menos em conjunto, como a pesca com timbó ou ainda os acampamentos na floresta quando da estação de coletas de determinados frutos, por exemplo. Disse mais ou menos porque sempre que presenciei tais fatos, os membros de cada aldeia, apesar de partirem para a floresta simultaneamente - ou quase - guardavam zelosamente seus próprios espaços e escalonavam as atividades de tal modo que não se misturavam durante a pescaria ou as coletas.

Mas a simples proximidade geográfica não é sinônimo de um estreitamento social, apesar de necessariamente significar boas relações, ou ainda uma indiferença complacente, ou, no mínimo, uma animosidade cautelosamente contida. $\mathrm{Na}$ verdade, em muitos casos, trajetórias migratórias convergentes podem colocar lado a lado grupos tão desconhecidos quanto dessemelhantes entre si; às vezes, as diferenças dialetais ou mesmo de idioma tornam ainda mais gritante a distância entre eles. Não obstante, se dois grupos cohabitam em um mesmo espaço da floresta é porque a paz reina entre eles - até porque seria francamente inviável a existência com inimigos do outro lado do bosque -; o que não quer dizer que pertençam necessariamente a um mesmo "bloco de população" como o chamaria Chagnon, a um mesmo "conjunto multicomunitário", no vocabulário de Albert, ou a uma mesma comunidade de origem, como venho chamando tais grupos. Nem que essa cohabitação venha a amalgamá-los em um só grupo.

Em 1996, testemunhei a reunião de duas aldeias, como estratégia de se fortalecerem frente a outras comunidades que habitavam a região de Roahikatiopë$u$, no Alto Demini, Amazonas. Estas últimas guardavam de maneira mais ou menos

\footnotetext{
${ }^{19}$ Ver Lizot 1984:118-121.
} 
ostensiva o acesso por parte de outras comunidades ao posto de saúde ali instalado pela Comissão Pró-Yanomami em meados da década. Isto significava não apenas usufruir dos serviços de saúde, tão necessários naquela região onde a malária é endêmica, como também ter acesso aos bens manufaturados, como ferramentas, armas de fogo etc. Em uma manobra ousada, os Hayasikiteri, cerca de 70 pessoas, e os Xotokomapiweiteri, somando pouco mais de vinte indivíduos, se juntaram, formando uma grande comunidade - para os padrões da região na época -, e instalaram sua aldeia a poucos metros do cobiçado posto.

O estratagema deu certo no início, com a "nova" aldeia desfrutando de um acesso imediato e ilimitado ao posto, mas logo ficou claro que tanto essa posição de força quanto a composição artificial da aldeia eram francamente inviáveis. Depois de alguns meses, a situação tornou-se insustentável: a audácia das duas aldeias foi encarada como uma franca provocação por parte das outras comunidades e as relações tornaram-se abertamente hostis. A união acabou por se desfazer quando, no verão daquele ano, um incidente com os Koherepiweiteri, os antigos habitantes do lugar, provocou a morte de um jovem Hayasikiteri; estes últimos foram então obrigados a deixar a região e se refugiar no Alto Orinoco, na Venezuela.

No entanto, mesmo durante este período, apesar de partilharem a mesma casa coletiva - xapono - e se relacionarem muito bem, as duas comunidades citadas nunca se pensaram como uma só; continuaram cada qual se denominando distintamente uma da outra, e ocupavam, como era de se esperar, espaços distintos e bem delimitados dentro do xapono. Ou seja, apesar da reunião, cada qual fazia questão de afirmar sua identidade e ressaltar o "afastamento diferencial" entre as duas comunidades.

Resumindo: na organização social yanomami, a aldeia, além de constituir a unidade relativamente independente do ponto de vista político e social, é autônoma no plano econômico; cada uma delas produzindo ou obtendo tudo o que necessita para sua existência material. No entanto, as relações com outras aldeias, às quais a unem laços de parentesco e de aliança - ou de hostilidade -, fazem com que cada comunidade, que pode contar com uma população variando de um pouco menos de vinte a 300 pessoas, seja inscrita em uma unidade mais vasta, delimitada por uma história comum remontando a algumas gerações. É no interior desse círculo mais 
amplo, esse conjunto multicomunitário, como o chama Albert (1985) que se articulam todas as interações sociológicas e fora do qual toda vida social yanomami perde seu sentido. Esses conjuntos, ou blocos de população, inscrevem-se por sua vez em unidades mais gerais e, por fim, as diferenças lingüísticas e de certos costumes marcam a fronteira entre os quatro ou cinco subgrupos que compõem o conjunto yanomami ${ }^{20}$.

Assim, é preciso sublinhar que se, de um lado, a autonomia de cada comunidade é real - fundada na auto-suficiência econômica e numa soberania política da qual as bases são estabelecidas por um espírito de independência e orgulho próprio beirando a beligerância ${ }^{21}$, do outro, não se deve esquecer a trama extremamente densa de interações intercomunitárias que caracterizam a vida social yanomami. Esta abertura para o exterior por parte das unidades locais discretas é bem comentada por Viveiros de Castro (2002:313), oposta a uma essencialização de unidades como tribo, aldeia ou etnia:

"Argumenta-se, por exemplo, que a idéia de uma humanidade dividida em unidades étnicas discretas, social e culturalmente singulares, deriva da ideologia do Estado-nação, imposta aos povos não ocidentais pelo colonialismo, esse grande inventor conceitual e prático de 'tribos' e 'sociedades'. Tal crítica (p.ex. Wolf 1988) tem-se traduzido em uma ênfase na interdependência dos sistemas sociais concretos (concebidos como superposições de redes sociais heterogêneas e abertas), onde as relações constitutivas de configurações regionais mais amplas determinam os processos internos às unidades locais (...)"

Poderíamos acrescentar também, lembrando Pierre Clastres (2004), que, nas sociedades em questão, esta abertura para o exterior se dá principalmente através da guerra com outras unidades do gênero - é o caso dos Yanomami, dos Tupinambá, dos Jivaro, por exemplo.

\footnotetext{
20 Albert (1985:109) assinala que "il est théoriquement permis de penser que ces 'blocs de populations' entretiennent entre eux des relations également fondées sur l'origine commune et ceci jusqu'au niveau global d'inclusion de l'ethnie", de modo que se poderia pensar (e restaria a averiguar) a possibilidade de um conjunto unificado por uma história compartilhada, de que a língua compartilhada seria a expressão mais evidente e, até agora, a que costuma ser considerada para se falar em Yanomami como um todo.

${ }^{21}$ Que, como é bem conhecido, teve uma popularidade singular e controvertida com a obra de Chagnon (1997 [1968]).
} 
Talvez algo parecido com a noção lévi-straussiana de casa pudesse dar conta mais satisfatoriamente do que chamamos de aldeia, pois ali os laços cognáticos são tão importantes quanto os agnáticos ou de qualquer outro que sugerisse uma relação de unifiliação. Além disso, a nossa noção de aldeia compreende muito mais uma origem comum, uma herança histórica, que englobaria o parentesco ao invés de fundar-se unicamente nele. Ouçamos o antropólogo francês:

"Il en résulte que, dans les sociétés "à maison", la continuité du lignage, jamais oubliée, se compose avec un autre principe: celui de l'alliance temporaire ou prolongée entre deux ou plusieurs lignages pour engendrer des unités sociales d'un nouveau type, où la façon dont les lignées s'entrecroisent e se nouent compte autant sinon plus que leur continuité. Dès lors, les oppositions traditionnelles employées par les ethnologues pour classer les formes d'organisation perdent leur netteté" (Lévi-Strauss 1991:434-45).

Assim, o futuro, bem como o presente e o passado, de cada grupo local são e foram determinados por relações de aliança e de hostilidade mantidas com outros grupos. As relações de aliança se articulam, de início, nas visitas entre as aldeias, na troca de bens materiais e, em alguns casos - quando a aliança se torna efetiva na interação matrimonial e na cooperação militar. Creio, no entanto, que é preciso levar em conta o caráter conjuntural e precário das alianças realizadas fora das comunidades de mesma origem. ${ }^{22}$

Parece-me, com efeito, que as relações de aliança e cooperação militar efetiva se restringem em grande medida, fundamentalmente, às comunidades aparentadas, ou comunidades de origem. É raro poder-se (ou esperar) contar com a confiança e o apoio fora desse círculo - que, por outro lado, não é tão limitado assim. Ao longo de um período como um século, por exemplo, uma comunidade pode dar origem a mais de uma dezena de outras. Para além desse nós ainda/sempre (kamiyë yamaki xĩro), encontramos muito mais uma acomodação pragmática, uma animosidade sempre contida, do que realmente aliança ou cooperação de fato.

${ }^{22}$ Ver, a esse respeito, Albert 1985:121-126; Do Páteo 2005:104-132; Chagnon 1997 [1968]:159164). 
Tive a oportunidade, de presenciar, em 2004 na Serra Parima, uma demonstração das dificuldades (e conseqüente fragilidade) inerentes a tais alianças entre comunidades de origem diferentes - cujo objetivo maior é sempre a parceria nos conflitos contra um inimigo comum. O porta-voz de um dos grupos, no contexto de uma negociação de paz com um grupo inimigo fez, sem o menor constrangimento, um mea culpa a respeito de sua participação numa emboscada contra este último, patrocinada por um outro grupo de aldeias, não pelo seu próprio. Como a tal investida fracassara e dela não resultara nenhuma morte, sua posição era bem mais cômoda; disse que tudo não passara de um ato impensado, não refletindo de maneira alguma seus verdadeiros sentimentos e que, de qualquer maneira, isto não mais se repetiria no futuro. Até 2006, a trégua estava sendo respeitada de ambos os lados.

Finalmente, no plano ritual, a aliança é expressa e reafirmada no endocanibalismo, no momento em que uma comunidade que foi o alvo de uma agressão mortal convida seus aliados a participar da ingestão dos ossos da vítima reduzidos a pó, antes de levar a termo as represálias contra a comunidade inimiga responsável pela agressão ou acusada de sê-lo - no caso das acusações de agressões xamânicas. E é aqui que reencontramos nosso tema, a morte.

Mas antes de entrar nele, é preciso ampliar nossa descrição do urihi para além das gentes vivas que compartilham de uma mesma perspectiva (Viveiros de Castro 1996, 1998, 2002; Lima 1996, 1999, 2005), a quem nós, não-yanomami, costumamos chamar exclusivamente de humanos. 


\section{Capítulo II - Outros humanos}

D ara entender o universo yanomami, é imprescindível dar-se conta de que ele é povoado por uma infinidade do que poderíamos provisoriamente chamar de espíritos ou imagens cósmicas; trata-se sobretudo dos hekura: os "espíritos auxiliares" do xamã (xaporı), que são responsáveis pelo equilíbrio do mundo e pela manutenção da vida tal como ela é - o que deve nos fazer compreender que auxiliar neste caso não significa de maneira nenhuma algo secundário, acessório. $\mathrm{Na}$ verdade, os hekura estão na origem de todas as coisas e seres, pois estão presentes desde sempre. Assim, o urihi (aqui cosmo) yanomami tem em seu topo (ou, num certo sentido, a base) da pirâmide sócio-cósmica.

Um texto fundamental a esse respeito foi escrito por Viveiros de Castro (2004) e se intitula "The Forest of Mirrors. A few notes on the ontology of amazonian spirits". O texto toma como ponto de partida justamente as reflexões de Davi Kopenawa publicadas em parceria com Bruce Albert em um artigo intitulado "Les ancêtres animaux" - traduzido em português como "O sonho das origens" - (Kopenawa \& Albert 2003).

Todos os xamãs yanomami afirmam categoricamente que, para conhecer os hekura, é preciso consumir epena ${ }^{23}$ ou yakoana, a droga halucinógena que inalam durante o rito xamânico. Em uma interessante analogia, Davi Kopenawa coloca o epena no mesmo plano em que para nós está a escrita:

23 Substância obtida através dos grãos da árvore epena hi (Anadenanthera peregrina, leg., Mimosaceae), ricos em N-dimetiltriptamina, composto psicoativo que está presente em outras plantas como o cipó Banisteriopsis caapi e no arbusto Psychotria viridis, com os quais se produz a Ayahuasca (Lizot s/d; 1976:117). 
"Para poder vê-los, temos que inalar o pó da árvore yãkõanahi muitas e muitas vezes. Isto toma tanto tempo quanto os Brancos demoram para aprender a escrever e ler"24.

Trata-se, na verdade, do alimento dos hekura e aqueles que não o inalam continuam com os olhos embotados: "The yãkõanahi powder is the food of the spirits. Those who don't 'drink' it remain with the eyes of ghosts and see nothing" (apud Viveiros de Castro 2004:2).

Inalado o epena, alimentados os hekura, o universo torna-se luminoso e no seu plano mais alto, o céu se abre para os xamãs que, então, alcançam todo o seu esplendor. Mas, quando os hekura se retiram novamente para suas alturas, tudo volta ao que era e o universo se fecha novamente. É preciso somente salientar que inalar epena, para os Yanomami, é uma metonímia usada para referir-se ao xamanismo, ou seja, "inalar epena" (epena këki koał) é sinônimo de praticar o xamanismo em yanomami. Mas para tornar-se um xamã yanomami é necessário, evidentemente, muito mais do que inalar o halucinógeno.

Apesar de ser uma atividade essencialmente masculina, há casos - bem raros, é verdade - de mulheres praticando o xamanismo entre os Yanomami; eu mesmo conheci duas que o faziam. Em certas regiões, principalmente a oeste da Serra Parima e nas comunidades do Norte do Estado do Amazonas, o xamanismo é ainda encarado como uma atividade necessária - e quase obrigatória - ao desenvolvimento intelectual e social de um homem adulto, como a última etapa de sua formação. No final dos anos 1990, na cabeceira do rio Demini, por exemplo, a maioria dos homens adultos e principalmente dos velhos que conheci praticava o xamanismo, o que, aliás, tomava boa parte de seu tempo. Impressão que também teve Kenneth Taylor, entre os Sanumá, do Norte de Roraima:

\footnotetext{
${ }^{24} \mathrm{O}$ que, bem a propósito, foi destacado por Viveiros de Castro (2004:: "In passing, note that if studious reason is the hallucination proper to Whites, then writing is their shamanism". No texto acima, Davi refere-se ao processo de aprendizado do xamanismo por que passa todo aspirante; na verdade, como já disse, os yanomami utilizam a metonímia "aspirar o pó da árvore yakoanahi" ou também huka thaprai: se fazer as narinas, quando referem-se ao xamã mais velho que ensina, já que, na maioria das vezes, é ele quem sopra nas narinas do noviço o pó yakoana ou epena, usando para tanto um tubo de bambu.
} 
"Das minhas primeiras impressões, uma das mais fortes ao chegar à terra dos Yanomami, no início de 1968, foi-me dada pela intensidade com que o xamanismo consumia o tempo dos homens. Parecia-me que seu cantar aos espíritos (hekula dïbi) era contínuo". (Taylor 1996:117)

Essa onipresença do xamanismo na vida yanomami é explicada pelo poder que se adquire ao praticá-lo, pois, na verdade, o xamã se transforma em espírito hekura, podendo, então, atraversar o espaço cósmico, recuperar a alma perdida de algum parente e salvá-lhe a vida, ou ainda, devorar a de alguém de um grupo inimigo, causando-lhe a morte, por exemplo, conforme diz Lizot (1976:166), sublinhando ao memo tempo a infinita capacidade de conhecimento que adquirem os xamãs:

"lls se transportent instantanément en des endroits lointains; horizontalement d'un point cardinal à un autre, verticalement pour atteindre le disque céleste ou pénétrer dans le monde chtonien; ils sont capables de décrire des contrées inconnues, de nommer des communautés ou des personnes connues d'eux seuls: leur savoir ne s'inscrit pas seulement dans les temps mythologique e historique, il s'étend dans un espace à trois dimensions".

O processo de aprendizado, no entanto, é longo e penoso; o noviço se abstém de qualquer contato com as mulheres, não se banha, não se alimenta ou o faz muito pouco, bebe pouca água e inala diariamente uma quantidade inacreditável de droga. No final de algumas semanas, ele se enfraquece consideravelmente e perde boa parte de seu peso. Os Yanomami dizem que, na maior parte do tempo, quem passa por esse processo se sente tornar-se outro, como conta Kopenawa em uma conversa gravada a respeito do xamanismo, realizada na sede da CCPY (Commisão Pró-Yanomami), em Boa Vista, no verão de 2005:

[O noviço] está fraco; apesar de comer, está fraco; apesar de caminhar, torna-se outro. Consegue ver os espíritos auxiliares, consegue ouvi-los. Então... o xamã mais velho o ajuda, o apóia. "Não se banhe!", ordena-Ihe. "Não se alimente! Não beba água! Quando uma mulher se aproximar, não olhe para ela! Tenha o pensamento fixo nos espíritos auxiliares!", orienta o xamã mais 
velho. O noviço então deixa de ter sede, deixa de ter fome e se enfraquece." 25 .

Por vezes, presenciei a iniciação de xamãs na região do Alto Demini, no Amazonas, e confesso que em alguns casos cheguei até a pensar que o iniciante não sobreviveria a tamanha privação e esgotamento (a este respeito, ver também Lizot 1976:117-136).

Durante a iniciação, o futuro xamã deve aprendrer a se relacionar com os hekura e isto significa principalmente aprender os cantos xamânicos, já que é através deles que dançarão os hekura - "fazer dançar os hekura" (hekura pë praiamat) é uma outra maneira de se referir ao xamanismo entre os Yanomami. Ele recebe dos xamãs mais velhos os hekura que o acompanharão em sua prática. De acordo com o relato de Kopenawa, esse período de provação é visto pelos Yanomami sobretudo como um processo de purificação:

"Consome-se primeiro a yekoana. Se não for consumida, nada aparece. Assim, inalada a yekoana, tudo torna-se luminoso; os xapori também se alimentam e, aí, o universo - para usar a palavra de vocês -, se abre por inteiro e, então, ficamos maravilhados. Os hekura não ficam no chão, mas no alto - flutuando, né? Em todo o mundo, no céu, lá no firmamento, na terra, tudo se ilumina - tudo fica luminoso. No entanto, se os xapori se vão de volta para o alto, as coisas retornam a sua aparência quotidiana e o universo se fecha de novo.

Quando meu sogro iniciou-me no xamanismo, eu sofri muito. Isto foi no início, quando principiava-me como xamã, quando ele limpavame das impurezas, quando eu era ainda ruim. Então, tornando-me puro, limpo, passei a escutar o universo inteiro, a escutar os hekura. Assim que cantavam, escutava-os e então tornei-me o que sou. À noite, durante o sono, olhando para todo o universo, consigo enxergá-lo, vejo-o dormindo. Apesar de dormir, no sonho, ajo como um xamã. É assim... Agora, por exemplo, os xapori estão em suas

\footnotetext{
${ }^{25}$ Texto em yanomami: "A uhutiti; a iai makii, a uhutiti; a huu makii, a në aipëai. Xapori pë taai, pë hĩrii. Inaha thë pë... a kuaai tëhë, yekuana koai. Patawëni huka horaprai; t̃ht tëhë a... a hũka horaiwent, a payeripou. "Wa yarimo no mai!", ĩnaha a kuu: "A ia no mai! Maũ upë koa no mai! Thuwë huu tëhë, mamo xatio no mai! Xapiri pë ha xĩro wa pihi kukei!", kuu tëhë... A amixi maprario, a kãe ohi iai pihio maprario; a kãe uhutitiprario".
} 
casas, para onde retornaram, pois não moram aqui, moram em outro lugar."

A maioria dos hekura estão relacionados aos animais da floresta - uma pequena parcela, aos fenômenos naturais, aos astros, a objetos da indústria humana ou ainda aos seres míticos, como os gêmeos fundadores da humanidade yanomami. Taylor relacionou nove tipos distintos de seres invocados como hekura: "animais, seres humanos, ancestrais mitológicos de plantas e animais, ancestrais mitológicos de de grupos humanos, espíritos maléficos (saï dïbï), plantas, arfetatos, o Povo do Céu (fenômenos humanóides, animalóides e celestes) e o Povo Subterrâneo" (Taylor 1996:123). Na verdade, podemos afirmar que os heróis mitológicos e hekura, se não são os mesmos seres, ao menos estão em um mesmo plano ontológico. Taylor tem uma explicação para esta proximidade:

"Quando os ancestrais sofreram a grande metamorfose e se tornaram animais, plantas ou grupos humanos, seus corpos transformaram-se nessas espécies e seus espíritos em hekula" (idem, ibidem).

Viveiros de Castro logo percebeu que os hekura ${ }^{27}$ são na verdade responsáveis por uma espécie de curto-circuito cosmológico na metafísica

\footnotetext{
${ }^{26}$ Nas palavras de Davi Kopenawa em yanomami: "Thë pë... yekoana koai pario. Yekoana koai mao tëhë, thë thaproimi. Yekoana a ha koarini... pei hapenaha wamaki kuu.... luminoso thë kuprarini, ĩhi tëhë xapori pë kãe iarinë, r̂hi tëhë, universo wamaki kuuwei thë ha karoprarinë, r̃hi tëhë thë pë totihou. Thë pë... pei maxitha hami thë pë praoimi, tire hamë - flutuando, né? Urihi kutarenaha, hutu mosi hamë, kihamë heaka hamë, maxita ... hamë thë pë wakaraprou - tudo fica luminoso. Ĩhi makii, xapori pë tirerayou tëhë, kõa kopuhuru tëhë, hwei kurenaha kua kõprario... thë hehua kõkei.

Kami ya... xoayëni ware a horai tëhë, ya në ohotaama - sofri, né? -, hapao tëhë, ya hekuramou xomao tëhë; ware a totihai tëhë, auprai tëhë, kami ya hõximaowei, xãmiowei; ware a auprarini, r̃hi tëhë, urihi kutarenaha ya hĩrii. Rari... xapori pë raria praukurayoma, ya pë ã hĩrirema; pë amoamou ha, ya waĩsipë hĩririnë, ĩnaha ya kuprarioma. Ya mio tëhë, urihi kutarenaha ya mirani ya taai - mahari taai. Ya mia makure, ya kãe mahari hekuramou. Inaha ya kuaama. Hwei tëhë, xapori pë naa nahiki ha pë ha kukini, pë piria. Hweha pë pirioimi, yayo hamë pë piria.

Ipa alma pataowei xĩro... pariki ha, Periporiwë a xĩro yahatoto... Inaha yanomae thë pë kuaai, kami yamaki, xamathari pë, ai thë pë urihi hamë thë pë kuaai hãthoo ya thë pë xĩro taimi".

${ }^{27}$ No texto, o autor - assim como os Yanomami orientais, grupo de Davi Kopenawa - denomina os espíritos auxiliares como xapiri - o pë é a marca do plural -,o mesmo termo usado para designar o próprio xamã. Já os Yanomami ocidentais distinguem claramente os dois: os primeiros são denominados hekura e o xamã, xapori. Assim, praticar a atividade xamânica é expresso pelo verbo hekuramou. No mais, realmente existe uma contaminação clara entre um e outro termo desta relação, que deve ter origem na "reverberação" entre uma e outra posição, como, aliás, já assinala Viveiros de Castro em seu texto a respeito (2004). Guardei a distinção presente no yanomami ocidental por uma questão de familiaridade, pois foi a língua que aprendi primeiro entre os Yanomami e também porque evita qualquer possível confusão a respeito do que estamos falando.
} 
yanomami - que, aliás, tem como um dos princípios primeiros a dissolução dos limites ontológicos entre as categorias de seres. Estão situados na interseção da animalidade (são chamados também de yarori - o que também quer dizer que são uma categoria de hiperanimais) e da humanidade (yanomami); talvez sejam mesmo os ancestrais humanos que existiam quando ainda todos os seres não passavam de uma potência, de um esboço do que se tornariam mais tarde. São yanomami, humanos - ou humanóides -, não só com o nome de animal: são na verdade uma hipérbole da espécie que representam, da qual guardam também todos os atributos, mas são ainda humanos - como todos, aliás, o eram todos nos primórdios dos tempos.

A humanidade de então era a categoria de ser não marcada, a categoria default, genérica; tudo e todos os que viriam a ser eram ainda e somente yanomami. Assim, os hekura atravessam também as categorias do tempo, já que se situam tanto no período mítico quanto no atual; são tanto personagens dessa primeira humanidade - situada, utilizando os termos de Viveiros de Castro (2004:7), no passado absoluto "que nunca foi pesente e nunca passa" - quanto se relacionam ainda hoje com os xamãs.

A yanomamidade está então por trás, ou melhor, por dentro de todos os seres. Passada essa infância dos tempos, cada um cumpriu seu destino, ao qual já estava desde sempre agrilhoado (visto que cada qual carregava o nome do animal em que se transformaria): uma infinidade de yanomami se transformou em uma outra infinidade de seres: porcos-do-mato, colibris, tamanduás e todos os outros animais que habitam a floresta. Hoje ${ }^{28}$ são bichos, caçados e comidos pelos Yanomami atuais. No entanto, a essência yanomami de cada espécie é encontrada no seu respectivo hekura - que, aliás, se apresenta ao xamã yanomami na sua forma humana. Kopenawa explica que os hekura são as imagens dos 'pais' dos animais atuais, ou seja, são as imagens dos ancestrais míticos, personagens da primeira humanidade:

\footnotetext{
${ }^{28}$ Ou aqui, onde estamos, no plano dos mortais, como propõe minha orientadora, considerando que o mito seria, sempre, um lugar e não um tempo; o chamado "tempo mítico" seria, antes, o lugar do "não-tempo".
} 
"Os espíritos são tão numerosos porque eles são as imagens dos animais da floresta. Todos na floresta têm uma imagem utupë: quem anda no chão, quem anda nas árvores, quem tem asas, quem mora na água. São estas imagens que os xamãs chamam e fazem descer para virar espíritos xapiripë. Esta imagens são o verdadeiro centro, o verdeiro interior dos seres da floresta. As pessoas comuns não podem vê-los, só os xamãs. Mas não são imagens dos animais que conhecemos agora. São imagens dos pais destes animais, são imagens dos nossos antepassados". (Kopenawa 1998)

Como analisa Viveiros de Castro (2004), "o conceito de xapiri, mais do que designar uma classe de seres distinta, anuncia uma região ou momento de indiscernibilidade entre o humano e não-humano", aponta para um background humano escondido em formas não-humanas, além de remeter a propriedades nãohumanas através das quais, e por intermédio dos xamãs, os humanos aumentam sua consciência (Viveiros de Castro 2004:5). E essa "zona cinzenta" abrange, aliás, a própria figura do xamã, que se vê não só associado a seus espíritos auxiliares, mas também confundido com eles. A exemplo do que acontece entre outros povos ameríndios, entre os Yanomami, as posições de xamã e de seus espíritos auxiliares acabam sendo permutáveis.

Aliás, como observei acima (nota 27) as palavras que designam o xamã e os espíritos xamânicos são também intercambiáveis - e isto pode ser observado em todos os cinco subgrupos lingüísticos yanomami, tanto no caso de xapiri quanto no de hekura; ora um designa o xamã, ora designa o espírito auxiliar e vice-versa -, indicando assim, mais do que qualquer outra coisa, a natureza relacional do xamanismo. Trata-se então, nas palavras de Viveiros de Castro (2004:6):

"something which one 'has' - an adjectival and relational quality or capacity rather than a substantive attribute".

Ainda neste sentido: o xamã yanomami e os demais yanomami (homens adultos que praticam o xamanismo em âmbitos restritos, mulheres, crianças e adolescentes) não estão em planos ontológicos distintos; os (propriamente e/ou reconhecidamente) xamãs não constituem um grupo discreto na sociedade. Como já foi observado, o domínio da relação xamânica é visto - pelo menos em boa parte dos grupos - como fazendo parte da formação de todo homem adulto yanomami e 
é, de uma maneira ou de outra, partilhada por quase todos. Entre os Sanumá, por exemplo, espera-se de um jovem ao sair da puberdade que já tenha aprendido muitos cantos xamânicos e os ensinamentos são muitas vezes transmistidos dentro do próprio círculo familiar, como nos relata Taylor (1996:125):

"Os primeiros hekura de um noviço são-lhe dados pelo pai ou avô paterno, às vezes, por um irmão mais velho".

Assim, podemos dizer que entre o que chamaríamos de leigo e o xamã há uma diferença quantitativa, de grau de investimento no aprendizado, e não qualitativa. Ouçamos mais uma vez Kenneth Taylor (1996:124) a respeito:

"quase todos os homens Sanumá podem fazer xamanismo, o que não ocorre com as mulheres. Alguém que faz pouco xamanismo em casa pode fazê-lo para sua família quando sozinhos em viagem pela mata, para afastar espíritos maléficos e para garantir o seu sucesso na caça. Porém se um membro dessa família cair gravemente doente, ele leva o paciente de volta para ser tratado por xamãs mais experientes".

No trecho acima, notamos que, se podemos falar de distinção, trata-se sobretudo da experiência e do grau maior ou menor de domínio da atividade xamânica. Ora, uma larga experiência pode se fazer necessária dependendo da importância do que está em jogo e da gravidade da situação que demande a intervenção xamânica. Taylor relaciona cinco exemplos de motivos que levam os Yanomami a praticarem o xamanismo; na maioria deles, trata-se de casos em que morte ou agressão estão presentes: defesa da comunidade contra ataques de outros espíritos enviados por inimigos; a cura de doenças; ataque a comunidades inimigas; para propiciar sucesso na caça e segurança face aos espíritos malévolos da selva durante a caçada; e, finalmente, fazer xamanismo só por fazer, sem qualquer objetivo específico, a não ser a de consumir yekuana, cantar e dançar (1996:122).

Além disto, é interessante sublinhar mais um exemplo do caráter duplo do xamanismo: na língua sanumá, o termo utilizado para designar a prática xamânica é õkamou. Ora, õka, em yanomami ocidental e também no idioma oriental, indica algo como feiticeiro, bruxo; alguém que se utiliza de sortilégios para matar ou envenar. Ouvi muitas e espantosas histórias a respeito no Alto Demini: suas vítimas - 
geralmente alguém que se encontrava sozinho na selva - são envenenadas, estranguladas, têm o pescoço retorcido e os osso quebrados.

Trata-se de uma de uma espécie de guerra suja, ou como diz Albert (1985:302), as investidas dos feiticeiros ôka remetem a uma forma de guerra secreta que é um prolongamento dos enfrentamentos armados abertos, tendo por conseqüência a continuidade do conflito entre as partes em questão, conforme relata um de seus interlocutores:

"[A]lors que d'autres gens avaient lancé une expédition de sorcellerie guerrière... après qu'ils aient brisé les os... qu'ils aient 'empoisonné'... des gens sont morts e la colère... le désir de vengeance qu'on suscités ces morts ont fait que les gens se sont mis à guerroyer dans les temps anciens..." (Albert 1985:303)

Lizot (s/d) descreve o õka, em seu dicionário, como alguém que sopra por meio de uma zarabatana certas substâncias mortais (hëri këkt) sobre os inimigos ou ainda que se empara da pegada que alguém deixou no caminho para enfeitiçá-lo. Nosso autor considera ainda que boa parte dos conflitos entre os Yanomami tem origem em acusações de tal feitiçaria e diz que o veneno mais utilizado pelos õka é o aroari këk $F^{29}$. Entre os Yanomami orientais e ocidentais, o feiticeiro õka não se confunde de maneira nenhuma com um xamã - que é denominado xapori ou hekura. Este último, apesar de, tal como o õka, aliás, atacar comunidades inimigas, não o faz utilizando-se de veneno ou de qualquer outro meio físico, mas através dos espíritos auxiliares.

\footnotetext{
${ }^{29}$ Lizot (1976:146-48; 1989:117-135) lembra que um mito yanomami atribui a Mucura (Naroriwë) a origem da feitiçaria entre os Yanomami. Foi Mucura quem primeiro utilizou uma substância venenosa para causar a morte de alguém. Por ciúmes e inveja, Mucura matou Mel (Yamonamariwë), com quem disputava a simpatia de duas mulheres que visitavam sua aldeia. Ora, Mucura não tinha nenhuma chance de conquistá-las, já que, entre outros defeitos, era feio e cheirava mal. Ao contrário, Mel era um Yanomami bonito e exalava o perfume das flores - conquistando de imediato o coração das duas visitantes. Ao se ver preterido, Mucura jurou vingança; no dia seguinte, utilizando uma zarabatana e um dardo envenenado, acertou mortalmente Miel em uma emboscada. Mucura também atingiu Lagarto (Refariwë), que, o reconhecendo, denunciou Mucura aos outros Yanomami da comunidade. No entanto, durante a incineração do corpo de Mel, momento em que todos lamentavam sua morte, Mucura, aproveitando-se do clima de consternação, acabou fugindo. Quando, mais tarde, foi perseguido, de tanto medo, metamorfoseou-se: brotaram penas em seu corpo e ele pode voar. Mucura buscou refúgio em um buraco em um rochedo, mas, seu esconderijo foi descoberto. Tucano (Mayepiriwë) pôde escavar a pedra com seu grande bico e Mucura foi morto. De seu sangue, as aves ganharam a cor vermelha em suas plumagens e transformaram-se em hekura, imortais, passando, então, a viver nos rochedos.
} 
Vemos assim que o xamanismo é também - e talvez mesmo sobretudo - o idioma através do qual se traduz a alteridade e, como tal, pode ser também referido como uma das modalidades da guerra ameríndia ou ainda como a filosofia social que a sustenta, mantendo de maneira determinante a ideologia centrada no grupo local. Ele responde por morte e doenças entre os humanos - do ponto de vista yanomami, é de fato o caso da maioria delas. Por isso, o xamanismo é uma instituição respeitadíssima e os xapori, operadores de vida e morte, gozam de um grande prestígio entre os Yanomami.

Enfim, toda ameaça à vida, toda morte é, em última instância, resultado de uma agressão sobrenatural, mais freqüentemente através de um ataque de espíritos (hekura) enviados por xamãs de outras comunidades inimigas ${ }^{30}$. Nunca tive notícia de uma acusação de xamanismo agressivo que tenha partido da própria aldeia da vítima, ou do grupo de aldeias aliadas partilhando história e origem comuns. Nesse nível, são mesmo raríssimas ou inexistentes as suspeitas de feitiçaria - distinta, sempre vale lembrar, do xamanismo.

Tal entendimento da morte se inscreve em uma elaboração maior, que, como já assinalou Albert (1985:341-342), nos remete a um canibalismo metafórico dos constituintes ontológicos da pessoa:

"Toda agressão humana efetiva (guerra) ou maléfica (feitiçaria... etc.) assimila-se para os Yanomami a uma predação dos constituintes vitais da pessoa: imagem vital ou o duplo animal. A associação da imagem vital com o sangue e do cadáver com a noção de kanasi ("resíduo, dejetos, restos") indicam, todavia, que essa teoria da predação imaterial remete a uma metáfora canibal mais direta" .

Essa predação simbólica da pessoa é associada a uma devoração biológica metafórica: enquanto o corpo da vítima se decompõe, ou é queimado, o homicida

\footnotetext{
${ }^{30}$ Mesmo uma picada de cobra será interpretada segundo este prisma e imputada aos malefícios de implacáveis inimigos, como atesta Lizot (1976:148): "D'une personne qui meurt des suites d'une morsure de serpent, on dit qu'elle est victime ou bien de la magie des õka ou bien de la sorcellerie des chamanes, et non pas de l'animal lui-même. Le nom du Bothrops [jararaca, responsável por mais de dois terços dos acidentes ofídicos entre os Yanomami] e celui du charme maléfique (aroari) sont formés à partir de la même racine".
} 
deve se submeter a um rito (unokai) que representa a digestão do cadáver. Sua alimentação, até o fim do rito, reduz-se a alimentos vegetais, sendo-Ihe proibido consumir carne de qualquer espécie. A associação com a digestão da vítima é clara, como demonstra o relato yanomami a respeito de um jovem caçador que, no final da década de 1940, flechara um seringueiro na cachoeira Shitoya, no Rio das Chuvas, na Venezuela:

"Quando chegou em casa, sem fôlego, por ter corrido sem parar, ele anunciou:

- Eu flechei um inimigo!

Ele vomitou logo em seguida gordura e cabelos, então ele concluiu que sua vítima estava morta e que ele havia comido sua alma" (Lizot 1976:12-13).

A devoração simbólica do cadáver da vítima está também presente no rico testemunho de Helena Vallero:

"Um homem que havia matado, depois de alguns dias, se sentou; ele fêz: scah! e ele soltou um verme pelo nariz. Então os outros disseram: 'Aquele que você matou não foi ainda queimado. Eles certamente puseram o corpo no alto, amarrado nas varas, e veja que os vermes já estão saindo' (...) Então o tuxaua disse: 'Os que nós matamos estão ainda frescos. Eles não os queimaram ainda"' (Biocca 1968:63-64).

Podemos também afirmar que a guerra, ou as investidas contra outros yanomami ou inimigos são claramente associadas ao canibalismo e à predação cinegética. Ora, as metáforas utilizadas para referir-se à guerra deixam isto muito claro, como esclarece Lizot (1996:111):

"Dans les dialogues cérémoniels, la guerre est assimilée à la chasse et partir en guerre se dit 'chercher à assouvir sa faim de viande'; les ennemis que l'on poursuit sont assimilés à des bêtes de chasse, les ennemis dont on est la proie sont des pumas ou des jaguars, des mangeurs de viande crue". 
O rito unokai, prescrito ao homicida ${ }^{31}$, é a contrapartida do rito funerário; a esse "exocanibalismo metafórico" (Albert 1985) corresponde um endocanibalismo real que são os funerais, quando os ossos do defunto serão comidos pelos parentes próximos e aliados, depois de receberem um tratamento "culinário". Nota-se que, no relato de Helena Valero colhido por Biocca e reproduzido acima, o homicida é ligado ao cadáver de sua vítima e sofre diretamente as conseqüências de sua decomposição. Se se trata para os Yanomami de uma metáfora, deve então ser uma metáfora forte, pois inúmeras vezes ouvi relatos de pessoas que afirmavam, como o personagem unokai de Vallero, ter regurgitado cabelo ou unhas da vítima.

Como podemos perceber, há então uma uma relação de reciprocidade unindo as partes; tudo se passa como se o bom desenrolar do rito funerário condicionasse a normalidade e o fim do rito unokai. Ouçamos o velho Esmeraldo, da aldeia Arokofithëu, a respeito do desdobramento do rito:

\begin{abstract}
"Realmente nós seguimos o rito unokai. Quando saímos para algum efrentamento, seguimos à risca o que os nossos ancestrais faziam em seu tempo. É pela manhã, quase ainda noite, que sempre nos aproximamos de nossos inimigos e alguém morre. A partir de então, quem matou não sairá mais até que termine o rito. Permanecerá sempre em sua rede; quando muito, sentará no chão ou em um tronco de madeira, pois ficará também muito tempo sentado. Desta forma continuará até o fim do rito, em seus aposentos, perto do fogo: levanta, senta, levanta outra vez, senta de novo. Quando o corpo [de sua vítima] terá se decomposto, quando abrirão [sua mortalha], só então, quando seus ossos serão pilados, o rito terá terminado. Cortará, por sua vez, o cabelo e se ornará com penugens de mutum
\end{abstract}

\footnotetext{
${ }^{31}$ Devemos ainda dizer que este rito está relacionado ao da menarca, cujas características se assemelham bastante ao rito do homicida. Aliás, de fato, os Yanomami consideram que a mulher que tem suas primeiras regras e o homem que acaba de matar alguém partilham ambos a condição de unokai, e, como bem lembra Lizot (1996:105): "Num e notro caso o desenrolar do rito é mais ou menos o mesmo e termina pela cerimônia idêntica, o paushimou [se embelezar com plumas e adereços]". A glosa indígena explica a associação dos dois estados pelo fato de em ambos haver sangue humano vertido, fato que desequilibra a ordem normal das coisas. $O$ esposo da mulher que se submete ao rito da menarca também sofre as mesmas restrições que ela, não sendo, no entanto, enclausurado em um recinto fechado como a esposa o é, durante cerca de duas semanas, período em que a comunicação com o resto do mundo é reduzida ao mínimo necessário e suas relações sociais praticamente interrompidas.
} 
e penas da calda de papagaio. Durante o rito, não come carne, só banana [assada]; sempre alimentos vegetais, carne nunca! ${ }^{32}$

Esmeraldo deixa bem claro que a decomposição do cadáver e o curso do rito funerário da vítima determinam o fim do rito para quem matou: somente quando os Yanomami estimam que os ossos de suas vítimas são reduzidos a pó - cerca de duas semanas após a morte - é que o unokai põe fim a sua reclusão e às restrições alimentares.

Outra prova do elo que se estabelece entre o homicida e o corpo de sua vítima nos é dado pelo costume de cobrir as feridas do defunto com substâncias veneno, como relata Albert (1985:389):

"on peut également saupoudrer les blessures de la victime avec des substances de sorcellerie afin de 'détériorer l'état d'homicide': unokai hoshimabramãf".

Apesar de tratar-se de ritos distintos, somos levados a crer que que ambos fazem parte de uma estrutura mais ampla, no seio da qual seu verdadeiro sentido pode ser encontrado nas relações mesmas que os unem. Mas o mais importante é que o rito funerário assume uma outra proporção que o unokai, que é um rito individual, uma contraparte discreta deste sistema maior. Já os funerais marcam os "tempos fortes" das cerimônias ligadas à morte; culminam uma grande assembléia, que por vezes reune várias aldeias, e, como veremos, toda a vida da comunidade será dirigida por seus imperativos. Mas antes de nos envolvermos num reahu, rito funerário, faremos algumas considerações acerca das reflexões no âmbito da

\footnotetext{
${ }^{32}$ Texto em yanomami: Trhi peheti yamaki onokaimou! Yamaki onokaimou. Hõoo! Yamaki wayu pata thë pë kuapenaha, r̃hi yama thë pree pou xoa. Pata thë pë niayou pariowei thë kuopënaha, yama thë thapou xoa. Yamaki wayu arayouwei, ahetekeiwei... hena tëhë, hena mahi tëhë, titi xoai kõ xo, ĩhi tëhë, nomarayou. İhi tëhë, a huimi hwetuu, a huimi hwetu, onokãe a huimi hetu, huu mai: kama e thoku ha a xoa xoa; a xoa xoa... roa xoa, pixita ha. Huu tihiki ha a tikëa xoa. Waiha, waiha, inhi a tikëa xoaa. Ĩhi waiha a piri-pirimou, a piri-pirimou... t̃ha wa pirikeiwei, wa katia totihikei. Yõro totihia mahitakeiwei... wa... wa piria. Innaha wa piria yõro mahia kukeiwei, inaha wa kutia wakë ha. Wa konohori upë kãyo yapramou, wakë a ha: "Xãi! Xëë!" A ithoa kõrayouwei, a roa kõkeiwei, a roa kõkeiwei... A hoterayou tëhë, a kaxiprareihe tëhë, rihi tëhë, ũku maroko hĩkiprareihe tëhë, ĩhi tëhë, hẽteheprario: a onokae maprario. İhi tëhë, hethaki hanimoa no muhurayou. Awei! Ei kure hami paari hesikaki yãta, yãta... Werehe xinaki hoo, t̃naha thë pë kuai, pata thë pë. Yaro pë waimi! İïh! Yaro waimi: koratha ki xĩro wai, nii kiki xĩro wai. Koratha ora kiki hoyaprai; hriki kiki wai... thë pë thaihe... yamaki kuai. Ĩnaha thë kuo kupere.
} 
etnologia sul-americana, mais especialmente aquelas acerca da morte, que nos precederam e constituem a base deste e de outros tantos trabalhos mais recentes. 


\section{Capítulo III - A etnologia das terras baixas sul- americanas diante da morte}

"E eu, pra onde vou eu?

Nós somos aqueles que estamos vivos. Estar vivo é bom"

(Hapóro, apud Carneiro da Cunha 1978:130)

M

orrer é sempre um evento dramático, tanto pessoal quanto socialmente - isto, todos sabemos e/ou sentimos ${ }^{33}$. Mas, ao que parece, em certas sociedades o é mais de que em outras - alguns anos de convivência com os Yanomami me forçaram admiti-lo. Talvez isso seja mesmo próprio de pequenas sociedades, de pequenos coletivos humanos, em que a morte marca um tempo forte. Enfim, de qualquer maneira, não podemos nos desfazer da impressão de que entre eles, do ponto de vista social e também no plano simbólico, a morte é especialmente elaborada.

A convivência ensinou-me, pois, que para entender os Yanomami é preciso compreender o que a morte significa para eles - cherchez la mort, eu dizia na Introdução. Mesmo levando em conta que, de uma maneira geral, ela constitui um ponto de vista privilegiado para entender traços essenciais de sociedades ameríndias. A morte, como já bem notou Carneiro da Cunha (1978:2), não significa apenas a extinção física e biológica de alguém, mas sobretudo dá partida a um processo de dissolução do homem social e

"[o] estudo das [suas] manifestações socialmente padronizadas permite, no processo de dissolução da personalidade social, entender-se o que precisamente constitui esta personalidade em uma dada sociedade".

\footnotetext{
${ }^{33}$ Não discutirei aqui a questão da oposição ou não entre saber e sentir. Ou, antes, seguirei LéviStrauss, considerando que não existe oposição e que não é por acaso que, em Portugal, o verbo saber tem tanto o sentido de "possuir conhecimento de" quanto de "ter o gosto de".
} 
Além disso, para uma boa parte das sociedades ameríndias - e os Yanomami não são exceção -, o fim da vida é sempre o resultado de agressão, de uma predação (humana ou não), entendida como devoração, como uma forma de canibalismo. Mas se, de um lado, o canibalismo representa a perdição dos vivos, de outro, também é condição para a salvação dos mortos, ou seja: o estômago é a sepultura última dos entes queridos, para usar uma expressão de Clastres (1972:262) a respeito dos Guayaki. Assim, a morte nos conduz às relações inevitavelmente caracterizadas pela marca da alteridade e, finalmente aos limites cardinais entre os domínios do humano e do não-humano.

Entre os Yanomami também, temas caros à etnologia ameríndia são mais facilmente abordados ou só se apresentam a nós através do discurso nativo sobre a morte, como é o caso, por exemplo, dos componentes da pessoa humana, predação etc. Mas não é só isso, podemos avançar que a morte é - também e principalmente - um operador de alteridade; é ela que instaura a própria diferença. Sem a morte, a figura do inimigo não passa de uma virtualidade, de uma potencialidade inscrita nas relações entre as populações das aldeias.

Esse atributo da morte, o de produzir alteridade, ou novas identidades, está também presente na mitologia yanomami. Como veremos, mesmo os personagens mitológicos (inclusive os gêmeos demiurgos Omami e Yoasi) surgem sempre quando um yanomami da primeira humanidade, ou dos primeiros tempos, é morto. A morte desencadeia a transformação, ou a alteração, essa noção capital da ontologia indígena, como diria Viveiros de Castro (2001:17):

"A real relação entre Eu e Outro, no mundo indígena, não é a oposição analítica ou a negação dialética, mas a metamorfose como alteração ontológica".

No caso yanomami, a morte é a condição dessa transformação.

É a morte que instaura efetivamente a figura desse outro Eu que é o inimigo. Não interessa a natureza da morte - se "matada" ou "morrida" -, ou melhor, trata-se sempre e de apenas uma natureza: predação, agressão. Como já mencionei, toda ameaça à vida, toda morte é, em última instância, resultado de uma agressão, mais comumente através de um ataque de espíritos (hekura) enviados por outros xamãs ou de algum funesto sortilégio. 
Nada de muito surpreendente nisso, nem de muito novo: a morte é um tema recorrente e fecundo na etnologia sul-americana, e bastaria mencionar trabalhos hoje clássicos como Os mortos e os outros, de Manuela Carneiro da Cunha e Araweté, os deuses canibais, de Viveiros de Castro, para provar o rendimento do tema. De fato, refletir sobre a morte - o fim da vida - é sobretudo cogitar sobre a própria existência, sua finalidade, sentido e duração. A construção simbólica (sóciocósmica) da morte, parece também ser uma porta de entrada privilegiada para a grande arena metafísica onde a pessoa ameríndia é criada, construída, destruída, devorada, eternizada, tal como apontado e realizado nos trabalhos mencionados ${ }^{34}$.

Foi nessa direção que seguiu a etnologia das terras baixas da América do Sul nessa virada de século. A recuperação de conceitos - tão velhos quanto a própria antropologia - como animismo e totemismo, que deixam o baú de relíquias dos séculos XIX e XX, para novamente figurarem nos textos e autores mais respeitados, nos indica também que os sistemas metafísicos indígenas passaram a ser o terreno privilegiado das investigações (Viveiros de Castro 2001).

Mas antes disso, o americanismo tropical fez um longo caminho. Segundo já muito se falou, sua história fora marcada, até os anos 1970, por tentativas de enquadrar a produção etnológica nos modelos pré-existentes, como lembra Seeger (1979:8):

\begin{abstract}
"Assim, Murdock apelidou os sistemas sociais sul-americanos de 'quase-linhagens' enquanto Nimuendaju foi criticado pela facilidade com que encontrava formas elaboradas de descendência e de prescrições matrimoniais onde tais coisas não existiam."
\end{abstract}

No entanto, o projeto Havard-Brasil Central inaugura uma nova fase nos estudos dos povos indígenas no Brasil, com o trabalho etnográfico ganhando em

\footnotetext{
${ }^{34}$ Magnus Course - ao que parece, esquecendo-se do trabalho de Carneiro da Cunha sobre os Krahó, realizado ainda na década de 1970 -, afirma que, em uma primeira fase de reflexão sobre a morte, a etnografia sul-americana tomou-a como um ponto de partida para especular sobre categorias metafísicas, cosmológicas, mais do que como um meio para desvendar a pessoa ameríndia. Somente mais tarde, influenciada pelos estudos acerca da Melanésia, é que a etnografia amazônica teria partido da escatologia para explorar os componentes da pessoa ameríndia, com Kelly, importando o conceito wagneriano de pessoa fractal, ou com o próprio Viveiros de Castro, falando do ameríndio como divíduo, por exemplo (Course 2007:79).
} 
extensão e profundidade. Quanto mais os pesquisadores se aproximavam dos interlocutores indígenas, mais se afastavam do repertório de questões que marcaram a história da disciplina em outras paragens durante o século XX, ou, pelo menos, da maneira como haviam sido colocadas.

Com a etnografia se afirmando nas terras baixas em meados da década de 1970, desde o início, os pesquisadores partilharam um certo mal-estar decorrente da dificuldade de se utilizar os conceitos tradicionais da etnologia - oriundos de investigações em outros continentes -, como linhagem, descendência, corporate groups etc., para compreender as sociedades ameríndias. Fato que marcou o simpósio sobre "Tempo e Espaço Sociais", organizado por Joanna Overing Kaplan no XLII Congresso de Americanistas, em 1976.

Uma insistente predominância das dimensões simbólicas sobre os outros planos mais empíricos da vida social já transparecia nitidamente nos estudos, como fica claro nessa defesa de Joanna Overing (1976:9-10):

" [...] we South Americanists are not infrequently accused of being idealist by our more 'empirically' minded or materialist Africanists or South East Asian colleagues. But if we are so, it is only because the Amerindians with whom we are dealing are also idealists when it comes to the ordering their societies".

Somos idealistas, em suma, porque os índios também o são.

Esse primado da ordem simbólica já fora muito bem sublinhado por Seeger, Viveiros de Castro e da Matta, em seu famoso texto "A construção da pessoa nas sociedades indígenas brasileiras", no qual argumentam que o uso de qualificativos como "fluídas", "flexíveis" etc. para as sociedades ameríndias sul-americanas poderia não passar de uma miopia ou ainda uma inadequação metodológica, visto que estas se estruturam a partir de idiomas simbólicos,

"que não dizem respeito à definição de grupos e à transmissão de bens, mas à construção de pessoas e à fabricação de corpos". (Seeger et al. 1979:10)

O fato era que as ideologias nativas a respeito da corporalidade representavam efetivamente o objeto privilegiado que emergia dos estudos dos grupos indígenas brasileiros de então. Para Seeger, não só as sociedades 
estudadas privilegiavam a construção simbólica da pessoa e o idioma do corpo em suas cosmologias, como também a etnologia precisava levar em conta essas ideologias para explicar os princípios estruturais dos grupos em questão, na medida em que $o$ arsenal conceitual da etnologia - forjado em outras paragens, no estudo de outros povos -, não se apresentava adequado para analisar as sociedades ameríndias sul-americanas (1979:2-3).

Não nos esqueçamos, no entanto, que, desde meados da década de 1970, Overing (1976:9) já apontara esse mal-estar entre os americanistas, discutindo a pertinência do conceito de filiação (descent) entre os grupos sul-americanos:

"My position is that 'descent' is a red herring. Rather, our analytical problem is that of phrasing order when we know order is there but have no language through which to express it. We have moities with their sub-groupings; we even have ancestors and ancestresses, albeit often vague in form; we have inheritance of statuses. But social time in Lownland South America is not genealogical time; time depth is a notion our South Americans tend to shy away from and, indeed, even war against. Thus 'descent' becomes an analytical concept that never quite fits. (...) Moreover, groups on the ground are frequently organized in accordance with a similar principle of parallelism: men with paternal male kin, women with maternal female kin. Such ordering can in no way be aligned to our traditional notions of 'descent' or 'filiation' forthcoming from our African models".

Desta forma, era todo o paradigma do parentesco, que surgira com tanta força entre os africanistas britânicos como a chave para abrir a porta da estrutura dos grupos tribais e de sua organização social ${ }^{35}$, que ruía por essas terras baixas. $\mathrm{O}$ que também já fora diagnosticado por Albert e Menget (apud Seeger et al. 1979:9):

\begin{abstract}
"Assim, abstrair destas formas de organização social o discurso do parentesco, como sendo um operador sociológico autônomo, que funcionaria recortando unidades sociais discretas e a partir de redes de interações produtivas genealogicamente fundadas, nos parece arbitrário, etnocêntrico e inútil”.
\end{abstract}

\footnotetext{
${ }^{35}$ A famosa afirmação de Radcliffe-Brown (1974 [1950]:11), de que "para a compreensão de qualquer aspecto da vida social de uma população africana, v.g. economico, político ou religioso é essencial conhecer a sua organização de parentesco e do casamento" fora, de fato, estendida para toda e qualquer população de pequena escala.
} 
Se, de um lado, a "magra" estrutura social é, ainda por cima, flexível e escapa sorrateiramente a uma apreensão mais rigorosa, de outro, vivemos em um universo de uma riqueza e efervescência simbólicas impressionantes, todas as dimensões do social são submetidas a esse idioma sócio-cosmológico, que têm no xamanismo a sua mais acabada síntese (cf. Chaumeil 1993).

Mas Joanna Overing já havia anunciado tudo isso nas discussões do XLII Congresso Internacional dos Americanistas, em 1976. Ela insistira então que até mesmo a unidade social sobre a qual assentar as análises não se deixava facilmente apreender: "We also have the related problem of 'corporation', indeed of what is a group, of how to phrase group structure and relations between groups". (Overing 1976:9). A posse ou propriedade da terra - que no continente africano era a questão essencial na relação entre os grupos (estruturados em torno do idioma da descendência e filiação) - parecia não ter a menor importância nas terras baixas; a transmissão de bens materiais de uma geração à outra também não vinha ao caso. Quando muito, tratava-se da transmissão de identidades, de bens simbólicos e, ainda assim, efêmeros, transitórios. Tratava-se, para Overing, de encontrar o idioma através do qual dialogar com as concepções e conceitualizações nativas de sociedade, como nos explica Tânia Stolze (2005:111):

"ela ressaltou que a questão não estava unicamente em conceitos
como "descendência" ou "grupos corporados", mas também em
outros como "grupo".

Acrescentando logo em seguida:

"Buscava-se assim desmantelar o esquema interpretativo fundado em noções como reprodução social ou continuidade social. Tais sociedades, indiferentes como sabem ser ao tempo genealógico ou à profundidade temporal, mais do que à sua perpetuação ao longo do tempo, dedicavam-se, frisava ela, a recriar-se de novo a cada geração, contando, para isso, com um sistema de categorias, não com um sistema de grupos".

Aliás, esta maior atenção às categorias nativas já era o que propunha Maybury-Lewis, coordenador do projeto Havard-Brasil Central. Conforme relata Sztutman (1992), em seu texto sobre a trajetória do etnólogo inglês, Maybury-Lewis sugeria a procura de novos intrumentos de análise, na medida em que aqueles que a antropologia dispunha então, criados para o estudo de povos da África e Oceania, 
não se mostravam operantes diante das realidades encontradas no Brasil central, entre os Jê e outros grupos. Sztutman (2002:453-454) comenta ainda que o grupo de etnólogos reunido em torno do projeto tivera que empreender a "dissolução culturalista":

\begin{abstract}
"ou seja, [dar] uma maior ênfase no estudo das categorias nativas de entendimento, priorizando aspectos ideológicos, no sentido que Clifford Geertz e Louis Dumont atribuem ao termo (jamais como mascaramento da realidade)".
\end{abstract}

Para tanto, a postura fundamental a ser adotada pelos pesquisadores era a de tomar as categorias nativas como via de acesso à compreensão dessas sociedades - em lugar de conceitos formulados em outros contextos etnográficos.

Essa aproximação em direção às categorias nativas levou a etnologia para longe de sua pauta tradicional de questões; um novo repertório de investigação se impôs: a produção e, mais tarde, a predação da pessoa, passando por um idioma do corpo, até uma política dos fluídos etc. Enfim, a cosmologia, a metafísica ameríndia, passou a não ser mais vista como simples passagem, mais ou menos apressada, antes de se abordar les choses sérieuses do parentesco e da organização social, mas sim como um objeto de estudo digno de interesse, conforme argumenta Viveiros de Castro (2001:6):

"Trata-se de prestar atenção aos discursos amazônicos sobre a ordem do mundo e a natureza do real, o que inclui o que eles dizem sobre a sociedade e o espírito humanos: não indiretamente e como que à sua revelia, em benefício de nossas filosofias do espírito humano, mas textualmente e como que deliberadamente, para o governo filosófico dos povos que os enunciam. E o que eles dizem (...) é que não há por que escolher, pois não há como separar, entre a natureza do real e o espírito humano, a ordem do mundo e o movimento da sociedade".

A própria Joana Overing (1976:10), por sua vez, de certo modo já anunciara toda a discussão que marcaria as décadas seguintes da etnologia sul-americana nesta sugestão:

"It is my suggestion that anthropological undestanding of Lowland societies is coming about only insofar as we have realized that social organization cannot be separeted from conceptual models and 
discussions, continually acted out in ritual form, about what it means to be human or animal, alive or dead, to be male or female, to be kin or affine".

Se o assunto, é bem verdade, não ofereceu desde o início uma abordagem fácil - nossa noção de pessoa ocidental tentando a todo momento invadir o espaço das categorias nativas -, é preciso, além disso, reconhecer que seria difícil separar hoje esse tema de um outro bastante em voga na antropologia da segunda metade do século XX: o da oposição natureza/cultura, o que, de saída, torna a matéria ainda mais complexa do que já é.

No que diz respeito à primeira dificuldade - a de, no fundo, vermos a todo momento o indivíduo ocidental circulando entre as categorias e instituições alheias parece que, se não chegamos a uma resolução, ao menos reconhecemos a confusão. Mas não é só; a imersão das reflexões sobre a construção da pessoa ameríndia no debate antropológico articulado em torno da desconstrução da oposição natureza/cultura deixa a discussão um pouco mais emaranhada. Entretanto, o que nos mostram os avanços teóricos mais recentes - penso sobretudo na reflexão acerca do perspectivismo ameríndio - é que, ao que tudo indica, a dificuldade apontada (esse desvio etnocêntrico) só pode ser resolvido dentro de um quadro que leve em consideração o fato de que a nossa própria ordenação do mundo, fundada sobre a oposição natureza/cultura, e, evidentemente, também portadora de sua própria concepção de pessoa, tende a enviesar a teoria antropológica.

Mas antes de tratar de culturas e naturezas, ocupemo-nos da relação indivíduo versus pessoa. Mauss é uma espécie de consenso como sendo o primeiro a lançar a discussão sobre a categoria de pessoa, com o seu texto de 1938 (1993). Seeger et al. (1979:5) também vêem "Une catégorie..." como inaugurando uma tradição antropológica de reflexão sobre o tema, que teria sido retomada por Dumont e Geertz, e que se distinguiria de uma segunda tradição - a da antropologia social "juralista", capitaneada por Radcliffe-Brown - por considerar as noções de pessoa enquanto categoria nativas, explícitas ou não; "enquanto construções culturalmente variáveis". 
Goldman (1996:85) também distingue nesse ensaio duas tendências que se disputam: uma relativista e outra evolutiva. A primeira acaba sendo o fruto do objetivo do próprio ensaio: ao traçar sua história social dessa categoria do espírito humano, Mauss acaba revelando a multiplicidade de modos particulares com que cada sociedade - histórica ou espacialmente distante da nossa - a elabora. No entanto, pressente-se no desenrolar da exposição uma certa determinação teleológica guiando as transformações por que passou a noção de pessoa: "Tudo se passa como se ele buscasse (...) o caminho que teria conduzido ao pleno reconhecimento de uma essência dada confusamente desde o início", comenta Goldman (1996:87). Essa essência seria a noção ocidental em sua versão mais acabada, a que toma o indivíduo como valor último da humanidade, ser moral e racionalmente autônomo, se relacionando com seus pares sob o signo da pura exterioridade (Viveiros de Castro \& Benzaquen 1977:139; Goldman 1996:93).

O fato de podermos enxergar no ensaio de Mauss um viés evolutivo - senão mesmo evolucionista - não nos impede, evidentemente, de sempre reconhecer seu imenso valor metodológico e sua revolução epistemológica ao priorizar as categorias nativas como a chave para a compreensão das práticas sociais concretas (cf. Seeger et alii 1979:5).

Ora, como lembram Seeger et alii (1979:6-7), foi a tradição juralista que produziu a maior parte dos conceitos da análise antropológica clássica da organização social, como linhagem, clã, grupo corporado etc., e, sobretudo, afastando-se de Mauss, assumiu e manteve a antinomia entre categorias nativas e a realidade objetiva, apreendida pela ciência. Esta última mantendo sempre e inabalavelmente 0 acesso ao real e, assim, a palavra final em termos de verdade. Como bem sintetizou Latour (2004:7): "comme si nous avions la nature et qu'ils devaient se contenter, eux, de leurs cultures". Como já vimos, os tais conceitos da antropologia social não se mostraram produtivos nas análises das sociedades ameríndias sul-americanas.

Mas, no que diz respeito à noção de pessoa, seria importante retomar um aspecto ainda não discutido com a devida atenção: o conceito de indivíduo biológico, suporte infra-sociológico da pessoa, que parece resistir através de todas as análises. 
A tenacidade com que tal noção se instala nas reflexões sobre a pessoa foi percebida por Goldman (1992:91-92), a respeito do ponto de vista de Dumont:

"a hipótese de um indivíduo 'infra-sociológico' subjacente às diferentes valorações culturais ameaça reintroduzir o essencialismo maussiano $^{36}$, não sendo casual que Dumont se esforce em determinar a existência de um 'indivíduo-fora-do-mundo' na Índia".

De fato, Dumont parece vacilar diante desse indivíduo empírico, dessa irredutível unidade proto-social. Logo no início de sua discussão a respeito das configurações holista e individualista das sociedades, adverte que é preciso, para evitar confusões e imprecisão, distinguir no 'indivíduo", de um lado, o agente empírico, matéria-prima da sociologia, e, de outro, o ser de razão, sujeito normativo das intitituições, representação ideal da sociedade ocidental. Mais adiante, recomenda mesmo "que se utilize outra palavra para designar o aspecto empírico", o que evitaria generalização, ou seja, de fazê-lo uma unidade de comparação, uma referência universal, projetando sua presença em sociedades onde é desconhecido. No entanto, antes de nos ensinar que o indivíduo é um valor, ou melhor, "faz parte de uma configuração de valores sui generis, Dumont afirma também que é preciso reduzi-lo "analiticamente a elementos ou a revelações universais que podem servir de coordenadas de referência comparativas (1992 [1966]:57). Voltamos, assim, ao indivíduo - porque, ao que se saiba, não se encontrou outro termo para substituir este - enquanto denomidador comum, suporte de toda experiência social.

O que vemos, então, é que basicamente o indivíduo se apresenta em duas configurações opostas, nas quais se repartem os grupos humanos: a holista, que caracteriza as sociedades "tradicionais", e a individualista, marca registrada das sociedades "modernas". E o que as opõe passa a ser uma questão de ênfase, que ora incide sobre a sociedade como um todo, sobre o "homem coletivo", ora sobre o "homem elementar". Aqui, nos sentimos quase ao lado de Durkheim. No primeiro

\footnotetext{
${ }^{36}$ Ou seja, segundo Goldman, de que cada configuração particular de pessoa, cultural e historicamente determinada, não seja nada mais do que uma manifestação específica das formas elementares da individualidade', cujo desenvolvimento mais acabado (ou hipertrofiado) seria o individualismo moderno. Como comentam Patrick Beillevaire e Aoban Bensa, tanto para Mauss, como para Durkheim, a individuação fora o resultado necessário decorrente da complexificação das sociedades e de sua diferenciação interna crescente (Beillvaire \& Bensa 1984:539).
} 
caso, a sociedade, sua ordem, subordinam cada homem particular, cujo dever é contribuir para a ordem global; no segundo, cada homem "elementar" é a medida de todas as coisas, "encarnando a humanidade inteira". O indivíduo é o fim e a sociedade, tornada uma coleção de indivíduos, é o meio; ou seja, o "todo" ontologicamente deixa de existir (1992 [1966]:57).

Assim, Dumont encaminha a discussão até um limite em que chegamos a pensar que realmente dissolverá a nossa persistente noção de pessoa/indivíduo. No entanto, só afirma que o indivíduo faz parte de uma configuração de valores sui generis - e que não devemos procurá-lo em vão onde sequer existe -, para mais adiante reafirmá-lo vestido em duas configurações, holista e individualista, dividindo, grosso modo, as sociedades humanas. Em um passe de mágica, encontramo-nos emaranhados na infecunda oposição indivíduo/sociedade em seu feitio mais habitual, ou, na melhor das hipóteses, nas oposição indivíduo/invariante/natureza versus pessoa/multiplicidade/cultura.

Certamente, no que se refere às sociedades modernas, e Dumont deixa isso claro a todo momento, trata-se de ideologia, de valores, não do que se passa de fato; tal sociedade, a idealizada pelo individualismo, nunca existiu; e mais ainda:

"O ideal da autonomia de cada um se impõe a homens que dependem uns dos outros no plano material bem mais do que todos os seus antepassados. Mais paradoxalmente ainda, esses homens terminam por reificar sua crença e imaginar que a sociedade inteira funciona de fato como eles pensaram (...)" (Dumont 1992 [1966]:59).

Assim, em que pese sua lucidez acerca da ideologia das sociedades ocidentais e seu esforço em situar o indivíduo moderno como um caso particular e histórico, com Dumont, não nos encontramos, em termos de análise antropológica, em uma posição mais adiantada a respeito da pessoa humana em geral: como, ou em que termos, a abordamos em outras sociedades? Neste ponto, chegamos a ser até desencorajados por ele, que, mesmo considerando que toda sociedade implica uma certa maneira de conceber os homens, pondera, entretanto, que nessas concepções de pessoa humana pode existir alguma coisa de fundamental para uns e não para outros. Portanto comparar as sociedades "sob o signo de sua concepção de pessoa humana" pode não ser o melhor caminho (Dumont 1992 [1966]:32). 
Talvez realmente não se trate de compará-las sob tal signo - ou sob qualquer outro, aliás. Porém, no caso das sociedades ameríndias, há várias indicações de que a concepção de pessoa pode ser a porta de entrada para o seu entendimento (Seeger et alii1979; Vilaça 1992; Kelly Luciani 2001; Goldman 1996). Como, então, abordar a matéria sem cair nas oposições fáceis, como por exemplo, suporte biológico/construções ideológicas, indivíduo/sociedade, natureza/cultura, natureza/sobrenatureza etc.? Talvez Latour nos indique onde procurar as respostas. E sua primeira e maior lição é a de devemos nos livrar do encanto de nossas próprias concepções.

Pensam os modernos que, em algum lugar e em algum momento de sua história (na Grécia, quando surge a matemática; na Itália, quando nasce a física etc.), a natureza tal como ela é, nua, sem maquiagem, externa e a-humana, se manifestou. Este fato transcendental inaugurou um abismo entre os ocidentais - os que realmente desvendaram a natureza - e os que vivem emaranhados' em suas próprias culturas e em suas interpretações desfiguradas da matéria. Os primeiros não se encontram mergulhados nas puras relações humanas (cultura), enquanto os segundos, submersos na cultura humana, que os preenche totalmente, raramente se relacionam com a natureza comme il faut - apenas eventualmente vêem as coisas como são (Latour 1994:98).

Assim, prossegue ainda Latour, essa grande divisão interna da humanidade explica uma segunda divisão exterior: somente nós distinguimos entre natureza e cultura, entre ciência e sociedade, enquanto nenhum dos outros é capaz de diferenciar o que é conhecimento do que é sociedade, o que é signo do que é coisa. Desta forma,

"[e]scapamos sempre da prisão do social ou da linguagem e temos acesso às próprias coisas através de uma porta de saída providencial, a do conhecimento científico (...). Nas culturas Deles, a natureza e a sociedade, os signos $e$ as coisas são quase coextensivos. Em Nossa cultura, ninguém mais deve poder misturar as preocupações sociais e o acesso às coisas em si" (Latour 1994:99). 
A desenvoltura que a Antropologia sempre manifestou em relação aos Outros fora fundada, assim, nas duas grandes divisões, que definiam nosso mundo de maneira particular, bem como sua relação com os outros. Entretanto, como pondera Latour, essas divisões não nos definem, nem tampouco aos outros; elas não são um instrumento de conhecimento:

"É, portanto, preciso contornar as duas Divisões ao mesmo tempo, não acreditando nem na distinção radical dos humanos e dos nãohumanos em nossa sociedade, nem na superposição total do saber e das sociedades nas outras" (Latour 1994:100).

A antropologia deveria, então, de acordo com Latour (1994:102), "retornar definitivamente dos trópicos" e, para se debruçar sobre a $s$ ditas sociedades complexas, estabelecer a simetria em três planos: tratar da mesma forma acertos e erros; se debruçar sobre humanos e não-humanos; e, finalmente, ocupar um terreno intermediário entre o tradicional e o novo, suspendendo qualquer juízo a respeito do que distingue os ocidentais e os outros. Esse programa que Latour elabora para uma investida contra todos os coletivos - inclusive o nosso - parece perfeitamente cabível para o nosso caso, as sociedades ameríndias, e para nosso tema em particular, a morte e a noção de pessoa yanomami. Ademais, Latour aproxima-se de uma certa etnologia ameríndia bem particular - penso no perspectivismo ameríndio ou no multinaturalismo de Viveiros de Castro e Tânia Stolze Lima - quando afirma que, se por um lado, esse programa obriga a Antropologia a perder sua ligação exclusiva com as culturas, por outro, a presenteia com a pluralidade de naturezas.

Quem sabe seja esse o caminho a experimentar...

Como conclui Descola (1996:98), parece inevitável que a supressão da idéia de natureza implique a ruína de todo o edifício de realizações ocidentais.

"But this intellectual cataclysm will not necessarily leave us facing the great void of Being which Heidegger ceaselessly denounced; it will only reshape our cosmology and render it less exotic for many cultures who are on the verge of embracing the values of what they believe is modernity". 
As conseqüências epistemológicas para a antropologia são claras, segundo ainda Descola: a principal é a obsolescência do debate entre universalismo e relativismo, ele próprio uma relíquia da dicotomia natureza-cultura:

"Ir além do universalismo e relativismo significa renunciar a tratar sociedade e cultura enquanto faculdades humanas e natureza física, como substância autônomas, abrindo, assim, o caminho para um verdadeiro entendimento ecológico da constituição do indivíduo e das entidades coletivas" (Descola 1996:98).

Argumentos razoáveis, principalmente quando nos defrontamos com as concepções ameríndias em geral, e yanomami em particular, acerca do caráter não só dos seres e das coisas do mundo, como também da própria pessoa humana. Entramos em um terreno onde as fronteiras do humano e do não-humano parecem estar irremediável e desconcertantemente emaranhadas. Descobrimos que, ao que parece, a natureza última dos animais é algo de bem humano ${ }^{37}$ e, de sua parte, o homem (gente como a gente) carrega consigo até sua morte uma essência, ou uma contraparte, bem animal... E isto, como veremos adiante, não é somente uma marca dos tempos mitológicos revolutos ${ }^{38}$, lembrada unicamente nos relatos míticos, ou ainda um aspecto pitoresco sem nenhuma conseqüência prática ou importante. Ao contrário: essa natureza humana dos animais parece fundar as bases do xamanismo yanomami e ordenar todas as relações sócio-cósmicas que regem a interação entre os seres, regulando a vida e a morte.

Já a imagem ou o duplo animal - ou melhor, não-humano - do homem o acompanha durante toda sua existência, em princípio, replicando sua trajetória como sua imagem refletida num espelho. Mas, tomemos cuidado: essa imagem não é só reflexo; ela pode - e muitas vezes isso acontece - tornar-se o pólo ativo e então o homem passa a sofrer as conseqüências de suas ações. Assim, se o duplo animal é ferido ou morre, sua contraparte humana sofre o mesmo destino. Assim, essa

\footnotetext{
${ }^{37}$ Viveiros de Castro (2004) analisa o tema com brilhante acuidade.

${ }^{38}$ Mesmo porque, como comentei acima baseado em conversas com minha orientadora, o mito pode ser pensado como espaço, lugar e não tempo passado e acabado, o que resolveria, de fato, esse imbroglio a que todo etnógrafo é condenado sempre que se vê levado a afirmar coisas do tipo: "isso está no mito - leia-se, tempo passado, da origem - mas continua valendo"...
} 
espécie de totem faz parte da própria pessoa yanomami, é um de seus componentes ontológicos, conformando também seus traços físicos e psicológicos, como veremos adiante ${ }^{39}$.

Mas não é só isso. A passagem de um mundo para o outro - do que nós consideraríamos o nosso mundo humano para o reino natural e vice-versa - é algo passível de ocorrer a qualquer um e a qualquer momento. Talvez nem seja o caso de uma ruptura do tênue equilíbrio que mantém mais ou menos estanque essas duas dimensões do cosmo. No que diz respeito aos Yanomami, temos a impressão de que se trata mesmo de um princípio que determina a existência dos seres.

Sobre esse impulso de transformação, de metamorfose dos seres, afirma Guimarães (2005:63), a respeito dos Sanumá:

"Os processos de transfigurações parecem ser infinitos e são motivados pelas mais variadas peculiaridades do corpo ou de suas expressões. Nessa dinâmica criadora e transformadora do mundo, não é somente o Sanumá que se metamorfoseia. A cada nova criatura que surge, novas transfigurações também podem acontercer a partir delas".

Assim, um temor sempre presente entre os Yanomami é o de se transformar em animal ou em qualquer outro ser desconhecido - infortúnio que pode ser expresso pelos verbos yaroai (tornar-se yaro, ou seja, caça/animal) ou ainda $x i$ wãrihiai (que traduzo por metamorfosear-se $e^{40}$; transformação em qualquer outra coisa que o humano).

Passemos agora para algo que poderíamos nomear, entre os Yanomami, de A transformação primeira e última, e falemos do ritual chamado reahu.

\footnotetext{
${ }^{39}$ A questão do duplo-animal entre os Yanomami é tratada em praticamente todos os trabalhos a eles dedicados, e por todos quantos tratam da morte entre eles. Ao voltar a isso mais adiante, proporei algumas considerações próprias a respeito.

${ }^{40}$ A diferença entre essas duas possibilidades de transformação estaria no resultado. Mas seria também possível - e interessante - compará-las em termos de processo. Gallois (1988) distingue transformações que podem ser revertidas de metamorfoses propriamente ditas, que seriam irreversíveis. Nos dois casos aqui mencionados, tudo leva a crer que se trate de transformações irreversíveis, mudanças de natureza; mas o ponto teria de ser investigado com maior rigor.
} 


\title{
Capítulo IV - Reahu, o "rito único"
}

\begin{abstract}
- m Tambores da aflição, analisando os rituais Ndembu, Victor Turner lembra que o rito assume a função de estocar e transmitir informação. No que diz respeito à natureza do conhecimento, o autor the assinala um caráter imperativo: são verdades fundamentais ou axiomas; em suma, os valores fundamentais de uma comunidade, no que estamos plenamente de acordo, aliás. No entanto, tentarei mostrar que o rito funerário yanomami serve também de quadro para os "tempos fortes" das interações sociológicas inter e intracomunitárias.
\end{abstract}

Podemos avançar que, no caso dos Yanomami, são os rituais e as cerimônias ligadas à morte que constituem o operador das interações sociológicas em todo o conjunto multicomunitário. Em última instância, é no interior dos rituais que decorrem da morte que se atualiza a vida social e política yanomami. Como veremos adiante, os funerais são precedidos por uma série de ritos e seguidos por tantos outros, que poderíamos facilmente estendê-los quase ao conjunto de atividades rituais yanomami; eles também articulam os dois eixos sobre os quais repousam as interações com o mundo exterior à aldeia: a aliança e a agressão, a paz e a guerra.

De início, vamos circunscrever o que poderíamos considerar como fazendo parte de maneira direta do rito funerário aos acontecimentos que vão da exposição do cadáver até a ingestão das cinzas dos ossos do defunto yanomami. Seguindo a ordem dos acontecimentos, a descrição do rito será dividida em quatro partes: o início do luto, a exposição do cadáver, a incineração dos ossos e a caça coletiva (henimou), e, finalmente, o reahu (a assembléia) e a ingestão das cinzas. Encontraremos, no interior de cada fase, episódios ou ações dos quais encontramos, seguindo os passos de Turner, "um arranjo específico de símbolos, de atividades e de objetos simbólicos." (Turner 1972 :13)

Assim, à medida que avançamos no entendimento dos funerais yanomami, percebemos que o rito, longe de ser um reflexo simbólico das relações sociais, é, ao 
contrário, seu próprio fundamento. Ou talvez devêssemos abandonar a tentativa de sempre buscar um plano primeiro de que tudo mais seria reflexo ou decorrência e, "lévi-straussianamente" tomar tanto a organização social quanto o rito (e quase tudo mais) como realizações de uma estrutura que subjaz a ambos.

Mas voltemos ao reahu: face à morte, ele dá à sociedade uma via a seguir, impondo sua lógica própria. Ele ratifica o inelutável - a própria morte - mas somente na medida em que há uma retificação: o pagamento da dívida de sangue. Antes disso, porém, é preciso atualizar toda a vida da comunidade. A cada ator assinala-se um papel, que, como veremos, é tanto simbólico quanto real:

"Na verdade, o símbolo não é somente o resultado de 'esquemas de ações intencionais' (para utilizar uma expressão de Nadel): é o produto de interações entre atores. Podemos dizer que alguma coisa du caráter dessas interações participa da forma simbólica final ou é contida nela. (...) Na verdade, o ofício que ele cumpre tem sempre um caráter representativo: no seu papel ritual ele representa um grupo ou uma categoria social. Ele representa a soma das interações características internas desse grupo." (Turner 1972:14)

\section{I - O início do luto}

Compassando o drama pessoal vivido pela família enlutada, a máquina ritualescatológica yanomami se põe em marcha desde que um membro da aldeia falece. A morte irá mobilizar não apenas a comunidade que perdeu seu membro, mas envolverá em uma rede de relações - que vão desde prestações e contraprestações rituais, intercâmbio de bens, casos amorosos, indo até ao enfrentamento armado, emboscadas ou fugas - tanto uma boa parte de seus aliados quanto de seus inimigos e desafetos. Assim, quando os Yanomami me descreviam um funeral, a ênfase sempre era posta nas relações sociais que a morte necessariamente desencadeia e determina. Ouçamos Morzaniel Iramari, da aldeia Watoriki, no Alto Demini, Amazonas, que teve a paciência de me descrever pormenorizadamente o rito funerário em uma conversa gravada em Boa Vista no verão de 2006:

"Ao realizamos um funeral, procedemos assim: quando alguém morre, antes dos preparativos da cerimônia, os anciões se reúnem e discutem os preparativos: "Como iremos proceder? De que forma realizaremos os ritos?", perguntam-se primeiramente. Mais tarde, 
tudo decidido, dá-se início aos trabalhos na roça. "Então, faremos primeiro as roças e plantemos banana. Tendo plantado as bananas, chamaremos em seguida os moradores de tal comunidade. Gostaríamos de realizar a cerimônia com a presença deles", planejam de início os mais velhos. "Farei então minha roça!", decidem eles. Feito o roçado, plantam-se as bananeiras, que crescem ao longo dos meses, devagar. Quando brotam os cachos e crescem as bananas, enviam-se os emissários às aldeias convidadas para participar da cerimônia" ${ }^{41}$.

A partir do momento em que a comunidade se engaja em um reahu, ela passa submeter-se à lógica rigorosa do rito. Como já percebemos no relato acima, cerimônia, convidados e produção alimentar vão de par. Acima de tudo, é a presença dos visitantes (hwama ou hama) que dá sentido à cerimônia; aliás, é a condição incontornável de sua realização, pois, definitivamente, para os Yanomami, não faria sentido algum um reahu sem a participação dos convidados de outras aldeias $^{42}$. De tal modo que a presença e a satisfação destes, garantida por uma hospitalidade que se traduz principalmente através da superabundância de alimentos, é a medida de uma cerimônia bem-sucedida. Consequentemente, a produção dessa fartura de comida - não só de a caça, mas também e sobretudo de produtos das roças, principalmente banana e mandioca - condiciona o calendário do rito.

Excepcionalmente, quando a morte de alguém cuja importância social é reduzida - caso de velhas mulheres ou crianças - se dá em um período de fartura, ou seja, quando as principais roças já estão começando a produzir, o reahu pode-se realizar dentro de um prazo mais curto, já que a abertura de novos roçados não se

\footnotetext{
${ }^{41}$ No original: Yanomae yamaki reahumou tëhë, f̃naha thë kua: ai yanomae thë nomarayou tëhë, yama thë axipë thaprarei tëhë, f̃hi tëhë pata thë pë nowa thayou pario, thë pë puhi kuu pario: "Awei! Wenaha yama a thapë tha? Wenaha yama thë ha thaprarini, pora yama axipë mohotiarepë tha?", thë pë kuu pario. Thë pë kuu ha huraprarini, hutu a thai xoaohe. "Awei! Hutu yama a thaprai pario; kora yama siki tiai. Îhi yama siki tiarini, t̃hi theri yama pë nakarei. Îhi yama pë nakai; t̃hi yama pë kãi reahumou pihio", thë pë nowa thayou pario: "Ya... hutu a thaprarei!". Thaprarini, siki tiarei, siki ha patarini... siki ha patarini, yanikini... Ĩhi tëhë, sikt... koraha siki harayou tëhë; siki hathõ; siki prei tëhë, ז̃hi tëhë, ai thë pë rĩa xoaiwei hami, thë ã ximaihe. Ai yanomae thë ximaihe: "Awei! Ĩht yama pë nakai pihio. Îhi pë hami wama pë..

${ }^{42}$ Somente nos casos de morte de um recém-nascido, de uma criança de pouca idade, ou ainda de um ancião que tenha se "apagado", ou seja, expirado pela força da idade - um dos raros casos de morte que pode não ser considerada como resultado de uma agressão por parte dos Yanomami -, a cerimônia poderá ser abreviada e não contar com a presença de convidados.
} 
faz necessária. Mas este é raramente o caso e - contrastando com o quadro quotidiano - reahu é sinônimo de abundância, de um consumo desmedido, quase desenfreado. Nesse sentido também vale a comparação que fiz, na introdução, entre o reahu e o potlatch...

Para tanto, todos se põem a produzir para o grande evento. Não só os parentes mais próximos e diretos do falecido, mas boa parte dos homens adultos de sua comunidade se compromete a contribuir para a realização da cerimônia, passando então a trabalhar em um ritmo mais intenso em suas roças, como nos explica Iramari:

"Dá-se então desta forma: quando um dos filhos morre, o pai abrirá um novo roçado. Outros parentes, assim desejando, também o farão. É deste modo que se procede. Tendo cunhados, estes também roçarão; o mesmo acontece se tiver irmãos. No caso das cunhadas, seus maridos, por sua vez, também roçarão para a cerimônia. Se um pai de família morrer, seus filhos abrirão as novas roças, mas outros, solidários, também o farão, para contribuir com os alimentos. É assim que pensam: "Claro! Vou plantar uma [nova] roça; assim, poderei também oferecer alimentos para a cerimônia. Vou plantar cana! Quero roçar com afinco!"43.

Quando ainda vivo, é o pai da pessoa falecida quem dirige a cerimônia, é dele a festa. Como dizem os próprios Yanomami, é ele quem possuirá as cabaças com a cinzas (pora axi thapou, literalmente em yanomami: guardar as cinzas) do morto. Caso contrário, em que o falecido tenha filhos adultos, estes poderão guardar as cabaças funerárias e organizarão, por sua vez, a cerimônia. Se acontecer de o morto não ter pai vivo ou irmãos adultos - que também podem se encarregar do funeral -, o irmão do pai ou o da mãe poderão possuir as cinzas; se não houver outra opção, em último caso, um afim da mesma geração (cunhado) do falecido cumprirá fa função de anfitrião da cerimônia.

\footnotetext{
${ }^{43}$ Texto em yanomami: Innaha thë kua: kama ihirupë kuo tëhë, a nomarayou tëhë, ... hutu siki taprarei; f̃hi tëhë, ai thëni siki tikei; ai thëni... siki tiai pihio tëhë, ai thëni thaprarei; ai thëni ai hutu këki thaprarei; f̃naha thë pë thaprat. Kama heri e kuo tëhë, hei e no siki thaprarei; hepara pë e kuo tëhë, hepara pëni

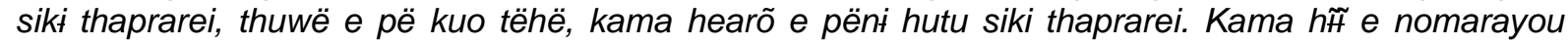
tëhë, ihiru pëni hutu siki thaprarei; ai thë pëni prea thaihe, thë pë rĩa payerayouwei; thë pë rĩa hipëiwei. Thë kuu: "Awei! Ipa ya siki tëai paxio. Ĩhi tëhë, ipa ya ki prea hipëi. Puu ya ki tëai! Yama a pree ohote thai pihio!", thë pë kuu.
} 
Assim, em princípio, a cerimônia é responsabilidade de um consangüíneo da linha paterna, próximo e direto do morto - pai ou irmão do pai, e também, se for o caso, um filho adulto. Na impossibilidade destes, a realização do ritual fica a cargo de um afim da geração ascendente. Ademais, se não houver alternativa, cabe a um afim de mesma geração. Por fim, no caso da morte de alguém sem nenhum laço efetivo na comunidade, qualquer um que se disponha - desde que tenha um mínimo de autoridade, frisa nosso interlocutor - pode realizar a cerimônia:

"Quando o morto não tiver parentes próximos, outra pessoa, que tenha um pouco de liderança e respeito por parte da comunidade, pode também guardar as cinzas. Então é assim que se dá: se a pessoa que morreu não tinha pai, não tinha mãe e nem irmão... se for sozinho, alguém outro [sem laços diretos] se encarregará da cerimônia. No caso de uma criança órfã, outra pessoa, geralmente quem a sustentava, quem a alimentava - se não tinha sogra viva -, alguém outro guardará suas cinzas." ${ }^{44}$

Vale lembrar então que é necessário já ter o statuto de pata, termo que congrega o que para nós seriam dois registros diferentes: o do tempo, significando homem velho, ancião, e o da qualidade, das virtudes, exprimindo grande homem. Assim, mesmo se morre seu próprio filho, mas o yanomami não é ainda considerado um pata, é seu pai (o avô do falecido) quem guardará suas cinzas e será o organizador, o celebrante da cerimônia. Enfim, tratando-se de uma mulher casada, tanto seus próprios pais, se ainda vivos, quanto o marido viúvo e família podem guardar suas cinzas:

"Se você for mulher e morrer, sua mãe estando viva, é seu pai quem guardará as cinzas; se sua mãe não for mais viva, é sua sogra quem guardará. Então se a mãe da morta não for mais viva, é a a sogra dela quem guardará as cinzas, assim se faz. Se seu filho morrer e você ainda for jovem, sua mãe guardará as cinzas. Se sua mãe já for morta, sua mulher... e você guardarão as cinzas; entretanto, se forem ainda muito jovens, cabe a seu pai guardar as cinzas. Se você for adulto, é você mesmo que irá guardá-las. É assim: Eu sou ainda

\footnotetext{
${ }^{44}$ Texto em yanomami: Thë pë mii t̃naha mao tëhë, ai yayo ani, waĩsipë patamouwei, axi kãi pree

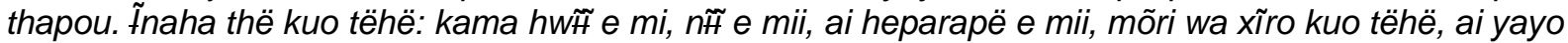

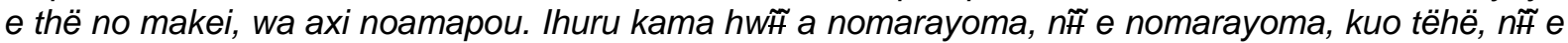
xĩro mao tëhë, ai yayo ani a payeripouwei ani, ohi thaiwei ani - pë yesiwë e mao tëhë - ai yayo a makei, thë no pree pou hwetio.
} 
jovem, minha mulher também o é. Se meu filho morrer, quem irá realizar a cerimônia? Meu pai a realizará. Se meu pai não se encarregar disto, se não for mais vivo, minha sogra, por sua vez, é que será incumbida de guardar as cinzas. Se eu não tiver sogra, minha mãe e meu pai guardarão as cinzas. É assim que se faz." ${ }^{45}$

A posse das cinzas do morto também pode - e, dependendo da importância política que teve em vida, deve - ser partilhada entre seus parentes. O que significa também a partilha das responsabilidades rituais. Ou seja: cada um que recebeu e possui uma cabaça com as cinzas funerárias tem a obrigação de patrocinar um reahu em sua própria aldeia. Assim, o funeral de um grande homem, um grande xamã, por exemplo, pode ser escalonado em várias cerimônias através dos anos e durar mesmo uma década inteira, multiplicando ainda de maneira importante as reverberações sócio-simbólicas deste evento. Mas isto veremos mais adiante.

Por enquanto, é importante frisar a obrigação incontornável de realizar o funeral que a posse das cinzas acarreta. Temos uma idéia disso através do relato de Helena Vallero. Ouçamos o pata Kachihéwé, que, durante o funeral de seu pai, dissera a Housiwé, marido de Helena:

"Eu os fiz vir para terminar com vocês a cabaça com as cinzas de meu pai. Quando tiver terminado, serei livre; os inimigos então poderão mesmo me matar. Tinha pressa por causa desta cuia; há muito tempo que viajo trazendo-a comigo. Quando a tiver terminado, estarei tranqüilo" (in Biocca 1968:122).

Com esta espécie de desabafo de Kachihéwé, podemos imaginar a dimensão do compromisso: para ele, o dever de realizar o funeral do pai era tão imperioso que ele não se considerava um homem livre até livrar-se da incumbência, e mesmo a possibilidade de morrer antes de fazê-lo era inadmissível. Essa preocupação é

\footnotetext{
${ }^{45}$ Texto em yanomami: Kaho thuwë wa kuo tëhë, wa nomarayou tëhë, aho naaho a xoao tëhë, aho naaho no axi pou; aho naaho a mao tëhë, aho yesi - kama thuwë wa pouwei -, yesiwëni axi kãi pou. Ĩhi a mao tëhë, aho naahoni aho thuwë pëha pora axi kãi pou, t̃naha thapou. Aho ihiru a nomarayou tëhë, kaho oxeo tëhë, aho naahoni axi pou. Aho naaho a mao tëhë, aho thuwë... Kaho [Kama] n $\tilde{H} e$ xë, warõ e xë, wahaki kuo tëhë, kaho waki no axi pou; thhi makii, wahaki oxeo tëhë, wa oxeo tëhë, aho hwaahoni axi xĩro pou, axi noamai. Wa patao hikio tëhë, kaho wani wa axi pou.

Inaha: kami ya oxe, ipa thuwë pree oxe; ipa ihiru a nomarayou tëhë, wetini pei a noamapë tha? Ipa hwaayëni axi noamai. Ipa hwaayëni axi noamai mao tëhë, a mao tëhë, ipa yaayëni a kãi pou, a kãi noamapou. Ipa sogra mao tëhë, ipa naayëni, ipa hwaayë xë, a noamapou. Inaha thë pë thai.
} 
recorrente naqueles que carregam o fardo da realização da cerimônia funerária, como recorda ainda Vallero:

"Eles não gostariam de morrer sem ter feito consumir as cinzas daqueles que amam, para que a alma possa ir livre para a casa do Trovão. É assim que eu sempre os ouvia dizer durante à noite em voz alta: 'Eu posso morrer, uma serpente, uma flecha... A morte não nos previne; ela chega sem prevenir. Eu não quero que estas cinzas fiquem aí; quero celebrar a festa'. A festa que eles chamam de réaho. Ingeridas as cinzas, Poréana torna-se Peikénéporébé" (idem, ibidem).

Note-se que Helena Vallero traduz reahu para o português como festa. A maioria dos Yanomami, espontaneamente ou, na maior parte das vezes, induzidos por nós, também fazem o mesmo. Percebi que invariavelmente os não-Yanomami tratavam a cerimônia yanomami estritamente como uma festa - não conseguiam enxergá-la também e principalmente como um rito funerário. $O$ frenesi, o entusiasmo e mesmo a alegria contagiante - que contrastam um pouco com o ritmo do quotidiano yanomami - acabam por se sobrepor aos outros aspectos, mais graves, do ritual.

É que o reahu tem realmente esta dimensão: de uma grande comunhão, de uma imensa celebração senão da amizade ao menos da socialidade; mais que uma festa, diríamos um grande festival: homens e mulheres cuidam zelosamente da aparência, ostentando seus melhores adornos e vestimentas; as noites são marcadas por canto e dança que só terminam, muitas vezes, quando o sol nasce na manhã seguinte; os jovens, principalmente, aproveitam a oportunidade para conquistar novos amantes; come-se e bebe-se como nunca - até "estourar", segundo dizem os próprios Yanomami: "Pëtirini, ya no hetirayoupi!", tradução literal: "estando cheio/saciado, estou a ponto de me romper". Na maioria das vezes, quase todo o produto das roças é consumido no período de uma semana.

É também durante a cerimônia que os Yanomami se dedicam a uma des suas atividades preferidas: trocar bens. O kula (ou, antes, seu gimwali cf. Malinowski 1922) dos Yanomami... Troca-se de tudo: cachorros, panelas, roupas, espingardas, munição, cestos, pontas de flecha, alucinógenos, calçados, redes etc. A troca serve, é claro, para se obter algo de que se necessite, um bom cachorro de caça, por exemplo, ou uma rede de dormir nova. Mas, o mais importante é a troca em si, o ato 
de trocar algo com seu aliado, mesmo que não consigamos obter nenhuma vantagem imediata na relação.

Pois a "simples" troca já inaugura uma relação senão de aliança ao menos de cortesia entre os protagonistas. Assim, assisti muitas vezes a trocas tão inusitadas como a de uma ponta de flecha por outra idêntica ou a de uma velha rede em trapos por uma espingarda nova ${ }^{46}$... É mesmo muito comum deferir o desfecho da troca; dá-se algo em troca de uma promessa de compensação, que pode mesmo durar meses, anos ou toda a vida. O que se procura nesses casos é envolver o parceiro em uma relação de crédito, de divida - o que bem pode ser útil mais tarde.

Certa feita, envolvido em uma negociação entre dois grupos de comunidades da Serra Parima para por fim a um conflito que já durava mais de uma década e custara dezenas de vidas, ouvi de um yanomami da comunidade do Loko, no platô de Surucucu, um argumento bem pertinente em relação ao que dissemos acima. Nosso negociador, que gravava uma fita cassete a ser remetida a seus arquiinimigos, propondo uma trégua no conflito, lembrava-lhes um gesto de boa-vontade de sua parte: anos antes quando as relações entre suas comunidades ainda eram amistosas - ou pelo menos pareciam -, ele Ihes dera, sem nenhuma contrapartida, um lote de inhames. Por mais de uma vez, o negociador da aldeia do Loko insistiu para que seus interlocutores da comunidade Waputha reconhecessem a dívida contraída e uma forma de quitá-la seria demonstrar, por sua vez, boa-vontade nas negociações.

Mas, retomando a descrição da cerimônia, é bem verdade então que em determinados momentos esquecemos de que se trata de um funeral. Tudo nos leva a considerar o rito muito mais como uma grande celebração da amizade entre aliados e que, no fundo, a morte não foi nada mais de que um pretexto para tal - e, de certa forma, é mesmo assim. Ora, não há nenhum aspecto da vida da comunidade que não seja profundamente afetado pelo reahu. Retornemos, porém, aos eventos que marcam o início do luto.

\footnotetext{
${ }^{46}$ Como todos bem sabemos, desde o "Ensaio sobre a dádiva" (Mauss 1993 [1924]), nenhuma troca pode ser dita "simples" se considerarmos que a troca, em si, é o próprio fundamento do social. Como sabemos também, o que conta não são as coisas trocadas, mas a própria relação que se efetiva ou se renova por intermédio delas, o que explica que se possa trocar coisas idênticas.
} 
Os xamãs dizem que eles põem fim ao tratamento espiritual quando as mãos de seu paciente, já morto, tornam-se frias (Albert 1985:383). Mas, a expressão mais comum para se referir ao fim da vida entre os mais diverso grupos yanomami é "a mixiaki hawërayoma", que é traduzida por "a sua respiração se extinguiu"47, assim como o fazem os Krahó, para quem a vida humana é conceitualmente ligada à respiração: “Um krahó é dito ratëk [morto] quando cessa a respiração: respirar é por excelência o ato vital" (Carneiro da Cunha 1978:10). A partir de então, os lamentos invadem o xapono, sucedendo à atmosfera criada pela cura xamânica, quando todos os xamãs da comunidade, e mesmo os de outras aldeias aliadas, estão engajados nessa luta contra a morte. Isso compõe um quadro bem impressionante; eles cantam, dançam, se drogam, invocam seus hekura (espíritos auxiliares) etc. durante dias inteiros.

Permitam-me ainda fazer mais um paralelo com o que disse Carneiro da Cunha a respeito dos Krahó; desta vez, sobre o lugar da morte. Para estes, o lugar da morte ideal é o local de origem; o krahó procura então morrer na casa materna, mesmo que isso signifique um sofrido percurso para o agonizante (1978:23). No caso yanomami, tenho a impressão que, mais do que morrer entre os seus, na sua rede, na sua aldeia, o lugar ideal - se existe - é os braços dos xamãs. Pelo menos, foi o que senti das mortes a que assisti. Quanto mais ela se aproxima, mais os xamãs se esforçam para estreitar o contato físico como moribundo, que, literalmente, morre em seus braços. Ele é segurado, apalpado, esfregado, massageado em um frenesi impressionante. Enfim, creio que, entre outras coisas, o moribundo não se sente sozinho, tomado pela solidão da morte que se aproxima ${ }^{48}$.

\footnotetext{
${ }^{47}$ Existem uma série de formas figuradas para designar a morte, como a citada no texto acima. Uma outra maneira corrente de expressá-la é usando o verbo cair: "a kerayoma". Ele caiu. Pode-se também usar a expressão "a kuaimi" - alguém não está, não é mais [entre nós]. Porém, entre próximos, dizer simplesmente que alguém morreu - a nomarayoma - é considerado algo grosseiro. Deve-se, assim, referir-se à morte através das expressões como "foi-se", "caiu", "sua respiração extingui-se" etc. Tal não é o caso, no entanto, quando se trata de membros de grupos com os quais as relações não são estreitas ou cordiais.

${ }^{48}$ Podemos também estabelecer uma relação entre o lugar da morte e o do nascimento. Se um yanomami morre em sua aldeia, nos braços dos xamãs, cercado pelos seus, ele nasce quase sempre na floresta, para onde a mãe se dirige asssim que percebe, com o rompimento da bolsa, que irá dar à luz. A maior parte dos partos a que testemunhei se deram à noite. A gestante se faz acompanhar pela mãe, irmã ou outra mulher e se retira sem alarde para um local na floresta próximo à aldeia. Terminado o parto, alguns minutos depois, a mãe com o bebê no colo retorna para a casa e
} 
Os parentes e as pessoas próximas ao defunto substituem então os xamãs e um coro de lamentações e choros rituais se estende agora a todo o xapono, onde, por sua vez, os moradores vêm se reunir nas proximidades dos aposentos do morto. Em uma atmosfera de intensa nostalgia, o defunto é então celebrado por todas as qualidades que ele teve (e mesmo as que não teve) durante sua vida. A tristeza demonstrada então transborda todos os limites e confesso que é contagiante; é quase impossível não se deixar levar às lágrimas por esta atmosfera de profundo pesar.

Nesse momento, aparece a primeira marca do luto: enxugando as lágrimas, os parentes tingem a face, de início, formando manchas de cor marrom; em seguida, criando uma negra camada mais ou menos espessa, formada de carvão misturado às lágrimas. Sobretudo as mulheres portarão esse sinal do luto durantes meses ou até mesmo durante anos - algumas viúvas não se desfarão mais dele. Em algumas regiões, como a da Serra Parima, em Roraima, por exemplo, os homens portam essa marca do luto tanto quanto as mulheres.

Após as lamentações, um ancião (pata të) toma a palavra para traduzir no plano político o diagnóstico dos xamãs. $O$ que quer dizer que ele incitará sua comunidade a se vingar da morte, exprimindo toda a raiva coletiva, conforme Albert (1985:387):

"Dés que les habitants de la maison, rassemblés auprès du défunt pour les lamentations collectives qui succèdent immédiatement au décès, rejoignent silencieusement leurs foyers, s'élève en général la harangue rageuse (hwërëamu hirai) d'un ancien (bata thë; le plus souvent le 'headman' de la communauté) qui entérinera sur le plan politique le diagnostic chamanique de la mort en appelant à la vengeance et en exprimant tout la 'colère' collective du deuil (hwishio tëhë: c'est le temps du deuil')".

Os parentes continuarão com as lamentações e velarão o corpo durante toda a noite. O tempo do luto ou das lágrimas (ĩkï tëhë) é também o tempo da cólera (huxuo tëhë). Mais uma vez é Helena Vallero quem nos traduz a posição yanomami

permanece sentada no chão durante várias horas. A placenta é embrulhada em folhas e pendurada em uma árvore na mata logo após o parto. 
face ao luto de um próximo, ao comentar a morte do próprio marido, a tristeza dos filhos e a reação de uma visitante:

"Meu filho continuava a me dizer: 'Mamãe, quero ir para junto de meu pai!' Mas seu pai não existia mais. A tia Ihe dizia: 'Não o procure mais, ele partiu'. Mas a criança o chamavama, chorando: 'Meu pai, meu pai'. Uma mulher Hasoubouétéri se aproximou e lhe disse: 'Não chore mais; você está wahati (frio) mais também os filhos daqueles que mataram seu pai estarão wahati; a boca deles também dirá: 'Pai', e eles procurarão o seus pais, porque, muito em breve, seus pais também estarão mortos'” (Biocca 1968:315).

\section{II - A exposição do cadáver}

Antes de mais nada, é preciso lembrar que há variantes segundo a filiação da comunidade aos diversos subgrupos yanomami. Por exemplo, entre os Yanomami Ocidentais, a exposição do cadáver pode ser simplesmente substituída pela cremação do corpo. Prática, aliás, também utilizada entre os Yanomami Orientais quando a morte acontece em condições extraordinárias ${ }^{49}$. Deste modo, durante uma viagem, quando o grupo se encontra longe de seu xapono, proceder-se-á à cremação do corpo o mais rápido possível, retornando-se à casa coletiva para realizar as etapas seguintes.

De madrugada, todos os residentes se reúnem de novo em torno da rede do defunto para uma última lamentação coletiva. Um ancião, consangüíneo direto, designa um afim classificatório (pëo, putativo; em oposição a yai, verdadeiro) da mesma geração que o morto e também residente, para, mais tarde, proceder à exposição do cadáver na floresta, depois de tê-lo protegido por uma mortalha em forma de cesto, fabricada com folhas de palmeiras trançadas - ou realmente de um cesto wii se tratar-se de uma mulher -, dentro da qual o corpo é colocado (Albert 1985:387-388). De acordo com a importância do morto, pode-se mesmo prolongar o

\footnotetext{
${ }^{49}$ Tampouco há exposição do cadáver no caso de morte de recém-nascidos, de anciões, ou ainda daqueles que tiveram uma conduta incestuosa: o corpo é imediatamente incinerado. "[L]es Yãnomamë pensent que les incestueux sont, comme les vieillards, affectés par un processus de dessiccation interne qui rend leur décomposition funéraire impossible", afirma Albert (1985:404-5), acrescentando também que, no caso do recém-nascido, dá-se exatamente o contrário: seu corpo é considerado "muito mole" e de sua exposição não restaria grande coisa.
} 
intervalo antes da exposição do cadáver na floresta por alguns dias a fim de que os parentes tenham tempo de vir assistir à cremação do corpo, como nos informa Helena Valero:

"Durante esse tempo, o velho pai de Fousiwé também morreu. Ele morreu enquanto voltávamos de uma viagem. Seu corpo ficou quatro dias sem ser queimado, para que os parentes tivessem tempo de chegar e de assistir à cremação; ele ficou suspenso em sua rede, sob o teto; ele inchou e ficou enorme. Depois foi queimado" (Biocca 1968:271).

Inicia-se então o primeiro tratamento ritual do cadáver. Despojado de seus enfeites, que serão queimados junto com todos os objetos que pertenceram ao defunto, o cadáver é colocado na posição fetal. Os punhos são fechados e postos de maneira a cobrir os ouvidos; seus olhos são cobertos com fiapos de algodão e, finalmente, seu rosto é encoberto por uma pequena cesta de vime.

O corpo é, em seguida, colocado dentro do cesto que lhe serve de mortalha. Tudo isso se dá ao lado da rede do defunto, próximo à parede externa do xapono (xĩka hamt), lugar feminino por excelência, de certa maneira, uma espécie de cozinha do espaço doméstico yanomami. Às vezes, se se trata de uma mulher ou uma criança, o cesto de folha de palmeira pode ser substituído por um cesto de vime (wï a ou xoto he). Antes de levar o corpo para a floresta, o afim designado para realizar esta parte da cerimônia deposita o cesto contendo o corpo no centro do xapono. Vale a pena assinalar a observação de Iramari de que se trata de um afim putativo e nunca um efetivo ${ }^{50}$. Geralmente, a tarefa é executada por uma só pessoa - mais raramente dois homens dela se incumbem.

\footnotetext{
${ }^{50}$ Quando perguntei:

- Heri eni?/Seu cunhado?

Iramari respondeu-me:

- Ma! Wa në heriai pëowei xĩro! Aho heriho a yai, a thaimi.De forma alguma! Mas sim aquele que é tratado [putativamente] de cunhado. O cunhado mesmo não participa!

O que vai ao encontro das informações de Albert (1985:387-88): "Cette personne, à laquelle incombera de procéder à l'exposition du cadavre à la forêt est - selon la norme explicitement soulignée par l'ensemble de nos informateurs - un affin classificatoire (bio) de même géneration que le mort et un co-resident."
} 
De modo que no funeral yanomami, tal qual assinalou Carneiro da Cunha (1978:143) a repeito dos Krahó, teríamos quatro grupos configurados: os consangüíneos, os afins, a comunidade e os mortos - grupo "subentendido e no entanto insistentemente presente". Para a autora, levando-se em conta que, entre eles, "a divisão fundamental é a que opõe os vivos aos mortos, e a continuidade dos laços de consangüinidade relegada ao segundo plano", pode-se entender a posição dos coveiros/afins entre os Krahó: "eles são, em relação aos consangüíneos o que os mortos são em relação aos vivos". Ou seja, conotam distância e alteridade; no caso yanomami esta (o)posição é levada ainda mais adiante, já que são são designados como "coveiros" os afins classificatórios, putativos - a categoria mais distante entre os co-residentes; os afins efetivos não conotando alteridade.

Aquele que é designado (sempre um homem) para cumprir os primeiros passos do rito, construindo o jirau na floresta - alto o bastante para impedir que animais consigam subir e violar o corpo -, também levará a cabo todas as outras etapas: carregará o corpo, dentro do cesto ou do estrado até o jirau, o erguerá contando para isso com a ajuda de todos os que se dispuserem, devido ao peso do fardo. Quando chegar o momento, pouco mais de um mês depois, descerá o corpo do jirau, o incinerará, recolherá em seguida os ossos calcinados e os pilará, transformando-os em pó, que será, finalmente, recolhido em cabaças lacradas com cera de abelha - este trabalho é considerado pelos Yanomami como muito penoso, como uma espécie de sacrifício pessoal. Muito mais tarde, quando da realização do reahu, da cerimônia propriamente dita, ele também auxiliará os parentes do morto na preparação da caça cerimonial que será distribuída aos convidados, como bem lembra Iramari:

"No caso de uma morte, procede-se da seguinte forma: você falecendo, se eu construo o jirau e suspendo o cesto contendo seu corpo, também serei eu que recolherei seus ossos e o incinerarei. Assim, sou eu mesmo que entregarei suas cinzas. Mais tarde, quando ocorrer a cerimônia, quando a caça cerimonial for preparada, eu ainda ajudarei seu pai; eu o apoiarei. Se você tiver irmão, eu o ajudarei; se forem dois, irei ajudá-los. Eu mesmo tendo suspendido o corpo de alguém no jirau, quem guardar as cinzas dele... Seu pai, por exemplo: se eu não ajudá-lo, causarei a antipatia de todos por mim. Dirão: 'Hooo! Este aí realizou a primeira etapa do funeral, mas não ajuda com a caça cerimonial!' Os que são 

encarregados das tarefas funerárias realmente trabalham duro!
Sofrem de verdade.... 51

Na floresta, a uma centena de metros da aldeia, o cesto é envolvido por uma esteira de varas, amarradas com cipó, e o fardo é então elevado sobre escoras, em uma sorte de andaime, feito de troncos finos de árvores, como já vimos (ver também Biocca 1968:267, 269). Ouçamos ainda Iramari a respeito:

"No momento em que o corpo é retirado para a floresta, ele é coberto por uma esteira de paxiúba. Quando ainda está na casa coletiva, é confectionada a esteira e o corpo é envolvido por ela; em seguida é suspendido no alto de um estrado (jirau). Muitos ajudam a fazê-lo, pois sozinho é impossível: é muito pesado. A madeira utilizada para construir o jirau deve ser reta e mais ou menos fina para que os animais não subam. O corpo fica exposto um mês, um mês e meio. No final do mês, quando as carnes já aprodeceram, quando aquele que foi encarregado de expor o corpo ver os ossos, alertará os outros: "Agora realmente acabou!" Então o assunto será debatido. Em seguida, cerca de 3 horas da tarde, todos saem da casa coletiva. Apesar de tudo, alguns não choram; moços e crianças, por exemplo. No entanto, se o morto for velho e respeitado todos deverão chorar e lamentar a morte - pois tratava-se de uma grande pessoa. Então, no alto do jirau, na esteira em que encontrase, os fluidos do cadáver já terão endurecido. Ele é descido e sua mortalha de paxiúba aberta, afastada do jirau. O que restou do corpo também é aberto e os ossos retirados. É possível que essa tarefa seja levada a cabo por duas pessoas. Neste momento, se você tapa o nariz e tem as mãos relutantes, todos se zangarão e reagirão com violência. Se o morto tiver irmão, cunhado, sogro, sogra, eles o amoestarão: "Não! Não faça isso! Que ofensa! Você vai apanhar", dirão enraivecidos. Sendo assim, mesmo que suas mãos estejam realmente sujas, que o mau cheiro seja insuportável, não tape o nariz e continue a catar os ossos e a colocá-los no cesto que está lá para isto. Se o fizer sem demonstrar mal-estar, todos ficarão contentes e não dirão: "Terrível! Você leva as mãos ao nariz!" E então se você se atrever a dizer: -"Mas isto cheira muito mal!",

\footnotetext{
${ }^{51}$ Texto em yanomami: Hei a nomaa hikirayou tëhë, a nomarayou tëhë... assim: wa nomarayou tëhë, kamiyëni ya paxira ahũ thakei; thakei tëhë, wï wa axi pë a ithoa kõmarëni, kamiyëni marõ toai kõo; kamiyëni wa ĩxia kõmarei; t̃hi tëhë, kamiyëni wa axi yaa kõprarei; t̃hi tëhë, wa wehe axi hipëkei. Waiha, reahu a kuprou tëhë, yaro a thai tëhë, kamiyëni ya payeriprai aho haaho a. Kamiyëni ya payeriprarei. Aho hepara a kuo tëhë, kamiyëni ya payeriprai, dois aho këki kuo tëhë, ya ki payeriprai. Kamiyëni yanomae ya thakeiwei, axi pora ya... Pora axi pouwei, aho hwaaho no axi pouwei ya payeriprai mao tëhë, ware no pree wãripouhe. Thë pë kuu: "Hooo! Kama a kĩaama makii, yaro a thai taimi tikoo!" Thë pë kĩaaiwei, thë pë pata kĩaai mahĩ! Thë pë në yai õhotai...
} 
outros membros da comunidade... todos, aliás, o repreenderão. Desta forma, calado e da maneira apropriada sempre se devem-se cumprir as tarefas funerárias e não de outra forma. Se não for assim, quando os outros virem fazendo-se incorretamente dirão: "Hoo! Não sabe o que faz. O que está fazendo? Não sabe fazê-lo!" 52

A decomposição do corpo estará terminada em cerca de três semanas. Os cantos e lamentações dos parentes serão então entendidos a cada dia, três vezes: pela manhã, ao meio-dia e à tarde, até que se confeccione a cuia que conterá as cinzas do defunto

Enquanto o cadáver é exposto, um trabalho sistemático é realizado para fazer desaparecer todo traço que o defunto deixou de sua existência; tudo: seus objetos pessoais, suas plantas em sua roça, tudo é destruído. Mesmo os cabelos de parentes e amigos, que, catando piolho, ele pôde ter tocado durante sua vida são cortados. As ferramentas de ferro são jogadas no rio, assim como a terra dos caminhos por onde o falecido possa ter pisado e deixado suas pegadas. Os abrigos onde possa ter dormido na floresta também são destruídos ou incendiados. Flechas que possa ter deixado fincadas no alto das árvores também são recolhidas e queimadas. Os postes de sustentação do xapono, onde amarrava sua rede são escrupulosamente raspados se não forem simplesmente substituídos (Albert

\footnotetext{
${ }^{52}$ Texto em yanomami: Urihi hami a hai tëhë, hapa, paxarahũ ha a titia parikei. Yano a ha, a wãximi pirio tëhë. Ĩhi tëhë, a ha yehiruhuruni, urihi ha, huu tihi pesi ha thaprarini he haroa kõprario, he ha haroprarini, tire ha, pihi kãi xatimakei. Prea thë pë no payeripraretayouhe - yamini thai tëhë, a thapraimi: hute yaro. Huu tihi xaari waĩsipë kuopëha, hãtho prea kuopëha thakitihini - a tuo maopë. A thakeiwei... mõri poripo a ha - mês e meio; final do mês - kuprou tëhë, a tarerayou tëhë, kama a no thakeiweini a maro taarei tëhë, thë pë nowa thai: "Awei! Hwei tëhë, a marõprarioma!", trnaha nowa thayou. Kama hore nowa thayou; nowa tharini, thë pë nowa ha tharini, kõmi - três horas pei mothoka kuo tëhë -, kõmi aa xoarayou. Îhi makii, ai thë pë r̂kiimi, oxe thë pë, hiya thë pë. Pata wa kuo tëhë, kõmi thë pë xĩro f̃kirayou. Kõmi thë pë xi îhukei... wa pataoma yaro. T̃hi tëhë, tire ha, tihi kuoha yuu thë pë hihukei tëhë, tihiki thaprariheni, tihiki maopë hami, prakiheni tihiki karoa xoaprarei. A karoprariheni, a ha karoprarini, wa tayoini, wa marõ karoa... karoprarini, f̃hi tëhë wa marõ toai.

Porokotai kupë kuo tëhë, porokotai ki marõ toapi. Ĩhi tëhë, wa huka hehuo tëhë, wa imiki mõyao tëhë, thë pë hixiorayou, thë pë yai waitherimorayou. Kama hepara e pë kuo tëhë, heri e kuo tëhë, pë xम̈ e kuo tëhë, yesi e kuo tëhë, thë pë yai hirarayou; a wãrireihe: "Ma! Ĩnaha wa tha no mai! Hõximi! Wa xërei!", ז̃naha thë pë kuu. Kua yaro, imiki xãmi mahĩ makii, hĩxia yëo kõhoikini, thë ki hĩthari mahĩ... hĩxia kõhoikini, imiki... imikini marõ-marõ hohokanopë titipou, sakosi ha... sakosi ha titimai, si ha îthakini; r̃hi tëhë thë pë xĩro toprarou, f̃hi tëhë thë pë xi toprarou, thë pë ã hwaimi: "Hõximi, wa imiki yareamou; huka imiki yareamou!" -"Ma! Thë rĩa hĩthari mahi!", kuu no kiriai tëhë, thë pë... ai pë peri thë pë, kõmi thë pë hirarayou. Innaha kua yaro, mamokai a xĩro thai, xaari a xĩro thai; hõximi a thaimi. Xaari thai mao tëhë, thë kãi hõximi thai taareihe: "Hoo! A thai taimi. Thai makii, weti thai tha? Wa thai taimi makii...", thë pë kuu.
} 
1985:391). Uma única vez tive notícia de exceção a esta regra, na região do Alto Demini, no Amazonas: apesar da controvérsia provocada a respeito, a arma de fogo que pertencia ao falecido fora poupada da destruição e doada a seus parentes ${ }^{53}$.

Os animais domésticos que pertenceram ao morto são também sacrificados, geralmente nos momentos seguintes ao falecimento, como tive a oportunidade de presenciar durante a morte de uma adolescente entre os xotokomapiweiteri, na primavera de 1996: os dois pássaros da jovem morta, um mutum e um jacamim, foram estrangulados logo em seguida; tiveram seus pescoços quebrados com gestos precisos e mecânicos, que são os de gente habituada a matar caça todos os dias. Um deles foi logo apanhado pela mãe da morta. A pobre mulher fez várias vezes a volta em torno da praça central do xapono, exibindo a ave tal qual um ser que não tinha a partir daquele momento mais nenhuma razão para existir, do qual a carcaça era um objeto imoral e de que era impreterível se desfazer, pois lembrava a existência passada da filha.

Entretanto, havia uma falta de vontade ou de firmeza no caso do cachorro da defunta; o sogro, sentado no chão, ao lado da rede da morta, chorando o corpo da sobrinha, tentava estrangular o cachorro com a corda de um arco, mas sem ser muito convincente. O cachorro, por sua vez, parecendo dar-se conta de que sua hora havia chegado, fingia-se de morto e se contentava em dar como único sinal de vida algumas olhadelas furtivas, que ele lançava do canto do olho para seu carrasco. Esse desfazia o laço, refazia-o e tentava - ou fazia de conta que tentava - matar o cachorro por asfixia, ao mesmo tempo em que chorava e se interessava por tudo o que se passava ao redor. Quando parecia que, finalmente, o velho yanomami tinha conseguido matá-lo, o cachorro o espiava do canto do olho. Finalmente, o animal foi esquecido e se retirou da cena fazendo-se a mais pequena das criaturas.

\footnotetext{
${ }^{53}$ Gabriel Coutinho Barbosa, em apresentação realizada no NHII-USP (11/05/2007), contava um caso comparável entre os Aparai e Wayana, que também destroem, tradicionalmente, todos os bens do morto: o de uma viúva que voltara para a casa dos pais após a morte do marido levando consigo aparelho de TV, DVD e motor de popa que pertenciam ao falecido. Para explicar o fato, o sogro do falecido lhe disse que aquelas coisas não tinham sido destruídas porque "são muito caras". Já a viúva afirmava que o próprio falecido a tinha instruído a guardar aqueles objetos para a filha do casal. Como observava então Barbosa, fatos assim parecem estar ocorrendo com cada vez maior frequência, em vários pontos das terras baixas, e merecem uma análise mais aprofundada.
} 
A destruição sistemática de tudo o que pode, de uma maneira ou de outra, lembrar a existência passada do defunto começa de fato desde a madrugada do dia seguinte à morte: uma fogueira é acesa na praça central do xapono diante do espaço familiar do morto e nela são jogados os seus objetos. Dependendo da importância da pessoa morta, a aldeia é definitivamente abandonada e estabelecida em outro local - o que, na verdade, é muito comum ${ }^{54}$. Os pertences pessoais do morto podem, no entanto, ser preservados até o dia em que suas cinzas serão ingeridas ou enterradas, quando, aí então serão definitivamente destruídos. Isso ocorre principalmente com os objetos mais intimamente relacionados ao corpo do morto, como os adornos de plumas, ou fortemente associados à sua identidade pessoal, como as pontas de flecha ${ }^{55}$.

Os Yanomami explicam essa supressão de tudo que lembre a existência passada do defunto por uma dupla necessidade: primeiro, a nostalgia, a profunda melancolia e a cólera que incita a lembrança de sua existência; em seguida, a extinção dos vestígios de sua existência terrestre permite ao espírito do morto (pore) de se desligar do mundo dos vivos e ir mais depressa para o dos mortos. A eliminação das lembranças compreende também o nome do morto, que nunca mais deve ser pronunciado por seus parentes e amigos.

\section{III - Henimou-incineração}

Quando as carnes já se decompuseram e o homem responsável pelas tarefas fúnebres percebe que os ossos do defunto já estão expostos, ele anuncia o fato aos membros da comunidade enlutada. Inicia-se a etapa seguinte do rito funerário. Uma grande comoção toma conta da aldeia, onde todos se reúnem, choram, e, no meio da tarde, partem para o local onde foi levantado o jirau. Somente às crianças e aos adolescentes é permitido não demonstrar seus sentimentos; se não chorarem,

\footnotetext{
${ }^{54}$ Parece ser comum à região guianense como um todo, a julgar pelas informações que tenho trocado com colegas membros da Pesquisa Temática em andamento no NHII-USP.

55 As pontas de flecha carregam claramente as marcas de seus fabricantes/possuidores, são diferenciadas e os Yanomami sempre demonstram um especial interesse por flechas diferentes daquelas que cada um fabrica.
} 
ninguém vai admoestá-los por isso. O pranto é a marca do luto. Velar um morto é, acima de tudo, chorar sua perda.

O que restou do corpo retirado do jirau é colocado no chão sobre a esteira de lascas de paxiúba para que os ossos sejam recolhidos. Este trabalho é feito sem pressa, meticulosamente, e aquele que o cumpre não deve de maneira nenhuma demonstrar algum mal-estar em tocar os restos mortais, apesar do mau cheiro, entre outras coisas.

Durante a preparação, os ossos são desprendidos de toda carne e colocados em uma ordem precisa dentro de um cesto de vime cilíndrico forrado de folhas. Esse cesto é feito pelo indivíduo considerado o celebrante da cerimônia funerária - um parente próximo e direto do morto ou sua esposa, que o guarda até a cremação. Esta acontece geralmente no dia seguinte ou dois dias após a preparação dos ossos e realiza-se sempre antes do amanhecer, já que a incineração dos ossos deve ocorrer inteiramente antes do dia clarear - o que acontece na região do equador por volta das 5 horas.

$\mathrm{Na}$ abertura do cesto, os homens e os xamãs da aldeia realizam uma minuciosa inspeção dos despojos, destinada, como lembra Albert (1985:412): "à confirmar ou infirmar o diagnóstico emitido na ocasião da morte". Digamos que eles estão à procura de índices que atestam a causa da morte. De fato, podemos dizer que procuram as formas das agressões simbólicas imputadas aos inimigos. $E$ isso serve também para definir ou redefinir, em um período de tempo razoável, o ajustamento político que cada morte provoca.

É necessário dizer que o diagnóstico se traduz no plano político por uma espécie de declaração de guerra ou a ruptura de relações com a comunidade acusada de estar na origem da morte. Em geral - e como ocorre em diversas paisagens etnográficas nesses casos - acusa-se os inimigos ou aqueles com os quais se está em maus termos, como foi o caso, no fim do ano de 1996, quando faleceu Roberto Wanapiutheri, um ancião muito respeitado por todos na região do alto Demini. Os xamãs da comunidade de Koherepiwei foram unânimes face à morte de seu grande aliado: a doença que pôs fim à vida do velho homem fora enviada 
pelos xamãs da aldeia de Hayasikiteri, então seus inimigos na época, tão temidos quanto odiados.

Esses últimos, após um confronto com os Koherepiweiteri, em que um dos seus havia encontrado a morte, fugiram para a região do alto Orinoco, na Venezuela. Inversamente, as mortes supostas ou reais de que tinham notícia entre os Hayasikiteri, os Koherepiweiteri as atribuíam a sua própria feitiçaria.

O que restou das carnes é levado de lá e enterrado na floresta, assim como a madeira utilizada no jirau é queimada. A este local, onde foram enterrados os restos mortais e queimado o jirau sobre o qual o corpo fora exposto, ninguém mais retorna. Torna-se um lugar de mau augouro, marcado pelo ódio. Os ossos recolhidos são então colocados no cesto, que é fechado e, em seguida, entregue à mãe ou à sogra do falecido, como já vimos. O cesto pode ser carregado no dorso - postura que é típica das mulheres quando transportam qualquer coisa -, ou, se assim o preferir, o yanomami encarregado pode levá-lo diante de si, segurando com as duas mãos.

Por sua vez, a mãe do morto - ou a mulher que se encarregará de conservar os restos mortais - deposita o cesto contendo os ossos em um jirau nos seus aposentos; todos os presentes choram o morto neste momento e, anoitecendo, todos se recolhem a seus lares. Ainda durante a noite, o cesto é retirado de lá e levado através da praça central do xapono. Os membros da aldeia, já despertos, levantam-se e se reúnem; este é um momento de grande comoção. É francamente mal visto aquele ou, principalmente, aquela que não chora, que, em represália, pode até mesmo ser alvo que alguma agressão. A obrigação é muito mais imperativa para os consangüíneos, pelo que notei dos exemplos de admoestação contra os insensíveis: - "Porque você não chora, apesar de ser seu irmão que está morto?!"; "Apesar de ser seu pai, você não chora, permanecendo dessa forma afrontosa!", conforme nos conta Iramari:

"Devagar se faz: vai-se colocando todos os ossos dentro do cesto. Encerrado o trabalho... todos os ossos recolhidos são colocados dentro do cesto. Tudo terminado, os ossos são guardados, o cesto é amarrado e carregado até a sogra do morto [ou outra mulher designada]. Se a pessoa não quiser carregá-lo [na postura típica das mulheres], poderá levá-lo segurando nas duas mãos. O que restou dos tecidos do corpo é enterrado e a madeira utilizada no jirau é queimada onde foi levantado. Neste lugar não se vai, ele passa a ser 
mal visto, a ser evitado, pois é onde o corpo é aberto, dissecado, quando a cólera se apodera de todos - trata-se da revanche. Levase o cesto então para a mãe do morto, que, em seguida, se for criança, o colocará em cima do jirau [sempre situado acima do local do fogo onde se cozinha os alimentos]. Quando o cesto é depositado no jirau, todos na aldeia passam a prantear o morto até o momento de dormir. Por volta das 3 horas... 4 horas... 5 e meia, dança-se com o cesto dos ossos em torno da praça central da casa coletiva. Todos levantam-se e participam: moços, moças... Se porventura alguma moça não chorar, as mulheres lhe serão antipáticas. Se por exemplo, você tiver uma filha e, no seu funeral, ela não chorar, outras mulheres a admoestarão; se seu irmão não chorar, todos se irritarão de verdade: "Porque diabos você não chora? Seu irmão de verdade faleceu e você não chora! Apesar de ser seu pai, você não chora e fica nesta atitude provocadora! Fica aí nesta atitude acintosa! Isso não se faz! Isso é péssimo!", dizem as pessoas. Se o morto for seu pai e você não chorar, os homens lhe dirão: "Espere e na hora de consumir yekuana, eu o golpearei na cabeça!" ${ }^{6}$

Durante a madrugada, os Yanomami dançam, choram e lamentam a perda de um dos seus. Todos os presentes participam de uma dança fúnebre realizada no centro da habitação; os parentes mais próximos do morto desfilam portando os pertences que tivera em vida: desde seu arco e flechas até suas sandálias, passando por calções, redes, o pote contendo seu halucinógeno e também o cesto que contém seus ossos, o qual, ao final, é depositado sobre o feixe de lenha onde será incinerado. Quando o fogo é então levado até o afim designado, ele não pode vacilar: deve incendiar a lenha disposta e incinerar os ossos sem demonstrar hesitação - caso contrário, provocará a ira dos parentes do morto. Ao descreverem esta parte do rito, os Yanomami fazem questão de sublinhar mais de uma vez que tal deve ser a atitude do afim e que dela não deve se afastar sob pena de sofrer a ira

\footnotetext{
${ }^{56}$ Yanikini thai, tititimai, titia hurakini... kõmi kutarenaha, thë pë kutarenaha, thë pë ha toatarini, thë pë titiakei... Thë ki toa huraa xoararini... okaa xoaprarei, haroa kõprarei, sako siha; haroa huraprarini, ñ̈ eha, yesi eha yai eha yehia xoamakei. Yehipou pihio mao tëhë, si maoa xoaohuru. Siki kãi ha yehimakini, siki hëprariowei, siki pihi kãi tikei. T̃ha, huu tihi wakë prea yaa xoakei; thë pë yaa, thakepë thaprarepehe. T̃ha thapehe, thë pë huimi, thë pë nëhë wãripouhe. Thë pë paxamaihe, thë pë paxeprareihe tëhë, thë pë hixiorayou; thë totihiimi; niayotima thë kutaëni. Ĩnaha thë kuwë! Sako siha

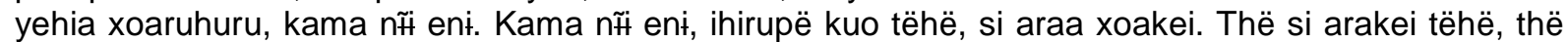
pë ĩkii, thë pë mikei. Ĩhi tëhë, três horas, quatro horas, cinco e meia thë kuprou tëhë, sakosi kãi erihõkeihe; ĩhi tëhë, yehia kõreihe; thë pë praiai kurenaha si kãi kuaaihe. Kõmi thë pë ithorayou, hiya thë pë, moko thë pë. Ai moko a ĩkii mao tëhë, thuwë pëni a nëhë kãi wãripouhe. Aho thëehe a kuo tëhë, a ĩkï mao tëhë, ai thuwë në a kãi përaihe; aho heparaha a ĩkï mao tëhë, thë pë yai hixiorayou: "Weti thë ha wa ̃̂kiimi tha? Aho heparaha a yai makii, wa ĩkiimi tiko! Aho haaho a makii, wa ĩkï no mai no kiriai. Thë hõximi! Thë totihiimi!", thë pë kuu. Aho haaho a kutaëni, wa ĩkiimi kuaai tëhë, "Waiha yakuana ha wa he xëi", thë pë kãyo kuu.
} 
dos parentes enlutados. A fogueira é montada na praça central do xapono, diante do espaço familiar do celebrante, a quem também será entregue a cabaça funerária (contendo cinzas do defunto) mais importante; as outras podem ser repartidas entre os cognatos do falecido. O que significa dizer que eles são também autorizados a organizar cerimônias funerárias. Na verdade, são mais que autorizados, são compelidos a isto, pois o ato de tomar para si uma cuia com as cinzas funerárias os obriga a realizar a etapa seguinte do rito (Albert 1985:416-417, 422).

Devagar o fogo vai fazendo seu trabalho. Lentamente os ossos vão sendo calcinados. Por medida de segurança, para livrar-se das emanações deletéreas da cremação, os jovens e as mulheres, além de evitarem a proximidade com a fumaça, se banham ainda pela manhã e as crianças também são levadas para rio e lavadas pelos pais ${ }^{57}$. Como se sabe ${ }^{58}$, para os Yanomami, a combustão de determinadas matérias constitui um processo extremamente nocivo, capaz de provocar doenças e mesmo a morte. E seu resultado inevitável, a fumaça, representa mais que um sinal inequívoco deste perigo, podendo ser ela mesma o agente que transmite ou causa o mal. Ela também é freqüentemente associada às epidemias ou aos agentes que as provocam, denominados de uma forma geral de xawara. Lizot (s/d:479) lembra que, para os xamãs yanomami (xapori), a xawara se apresenta em forma de luz e que, para combatê-la, eles são obrigados a se borrifar água.

Contando com a ajuda de um graveto, colhe-se os ossos das cinzas, colocando-os, em seguida, em um cesto. O trabalho é feito sem pressa, com cautela, pois as brasas ainda estão ardentes e nenhum osso deverá ficar para trás.

\footnotetext{
${ }^{57}$ Nas palavras yanomami: Thë pë niaiwei, yakuana pë, xaraka pë, poo pë, sandália, calção, rede, thë pë pouwei; thë pë kãi kõmi praiaihe, thë pë pouhe imikini. Thë pë kãi yokouhe... Ĩhi tëhë, thë pë kãi yokouhe, cinco e meia thë kuprario tëhë, thë kua mahĩprario tëhë, si kãi xokeai tiporepraihe tëhë; pei a xatimakeiwei kupëni, ĩhi tëhë, wakë a rramapokei, wakë a yapukei, wakë a maopoimai. Maapoimani, kahu a mamokaha, lata mamokaha, praa xoakei, wakë a; thë ha prakini, waa mahirayou tëhë, a kãi nakaa xoarei: "Awei! Hwëyëmi wa huimai!", kua xoarayou. İhi tëhë, tëi tëhë, thë pë hixioimi; tëai mao tëhë, thë pë xĩro hixiorayou - wakë a. "Yaaimi tiko tharei!", thë pë xĩro waitherimorayou. Kõmi thë pë xëyorayou! Kuwë yaro, tëa xoaoni, yaa xoakei. Yaakini, si xaari hãthomai, siprarema no mai; yapëkai:

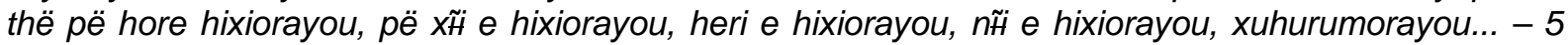
horas da manhã. Thë harumaihe... thë sako si thakei, titiimatayou, thë thakei; yanikini... xaari ĩximai; f̃hi tëhë, thë ĩximai ha, hiya thë pë, thuwë pë kõmi yarimou, uxi thë pë... thë pë... xawara pëha, thë pë pihi kuu yaro. Seis horas da manhã, sakosi yaua tëhë, thë pë yarimou.

${ }^{58}$ Albert desenvolve o tema num brilhante artigo de 1992.
} 
Em seguida, pila-se os ossos em um pequeno morteiro cavado no sentido do comprimento de um pequeno tronco, medindo cerca de um metro. Creio que há um paralelo entre $o$ aspecto do morteiro e o do imenso recipiente onde será armazenado o mingau de banana, que será ingerido mais tarde. Vale lembrar que todos esses objetos são finamente pintados e ornamentados.

As cinzas piladas são então armazenadas nas cabaças (horokota), e, assim como os ossos, são também entregues à mãe do morto ou à mulher designada para guardá-las, que, em seguida as depositará no jirau de seus aposentos - que é aquele do celebrante -, armado bem acima de onde se acende a fogueira.

Iramari continua descrevendo:

"Terminada a incineração, cessam as lamentações; em seguida, quase todos banham-se no igarapé: moços, mulheres... só alguns poucos não o fazem. As crianças, todas elas, banham-se. Enquanto isto, os ossos são incinerados, o que se termina por voltas das 7 horas da manhã. Os ossos são realmente calcinados. Você os apanha e os coloca no cesto com a ajuda de gravetos, pois queimaria a mão nas brasas se não procedesse assim. Terminado de recolher todos os ossos, eles são pilados em um pequeno morteiro; os velhos também ajudam. Neste momento, todos choram. As cinzas são então vertidas nas cabaças pela mãe do falecido. Tudo se passa na praça central da casa comunal. As cinzas são então acondicionadas nas cabaças e estas colocadas em um cesto, que é, por sua vez, pendurado no jirau situado acima do fogo nos aposentos da família. É assim que fazemos no funeral. A madeira utilizada para manipular os ossos é queimada, as cinzas são enterradas na praça central."

Crendo não correr tantos riscos quanto as mulheres e os jovens, os homens adultos ou mais velhos podem negligenciar o banho; são eles os "alguns poucos" que não se banham nesse momento do rito. Tudo o que foi utilizado na incineração deverá ser queimado e enterrado onde foi acesa a fogueira:

"Ninguém se aproxima do lugar onde foi acendida a fogueira porque os pés apodreceriam se o fizéssemos. Se as crianças se aproximam, são advertidas: "Não se aproximem! Seus pés apodrecerão!". É assim que se faz"59.

\footnotetext{
${ }^{59}$ Texto em yanomami: Yaa tuteo tëhë, îha thë pë ŕkï huraprario, ĩharani thë pë yarimou, maũ-u hami; ai hiya yarimou, ai thuwë pë kãi yarimou; ai thë pë yarimoimi. Oxe thë pë xĩro kõmi yarimou. Ĩnaha thë
} 
Incinerados os ossos e as cabaças contendo as cinzas sendo entregues à mulher designada a velar por elas, dá-se por finda esta etapa do rito. Diz-se então que somente os parentes mais próximos, sobretudo a mãe do morto, devem chorálo. Os demais estão desobrigados de fazê-lo; terminam-se os lamentos - o que contrasta com o início do luto, quando o corpo ainda estava exposto na floresta: ocasião em que todos choram copiosamente o morto. Durante este período, quando sua mãe ou um parente próximo, como o irmão, por exemplo, choram a sua perda, todos os presentes na aldeia respondem ao pranto, chorando por sua vez. Quando alguém se recorda de suas maneiras ou de alguma característica do morto, todos choram e lamentam sua perda. Este período do rito é denominado por uma expressão, no mia pou ou mia no pou, que significa que alguém morreu e o rito está em andamento, que se está a prantear o morto. Uma vez incinerados os ossos, a maioria deixa de chorar o defunto até a ingestão ou o enterro das cinzas, quando o falecido será chorado por todos e pela última vez.

Desta feita, não só os membros de sua comunidade, mas também os convidados de outras aldeias chorarão o morto.

"E é por isto que nos convidamos uns aos outros. Não o fazemos à toa: é para chorar os mortos que realizamos o reahu. Se não houver morto não realizamos a cerimônia à toa".

No entanto, na época de fartura ou na estação de certos frutos apreciados, como a pupunha, por exemplo, realizam um festival parecido. "Festejamos sem motivo", argumentam:

pë ha kuaani, frha si yakeiwei, t̃ha si wakë maa xaarimakei; ũko ĩxia xaarimareihe; ĩxia maa xaarimakini, huu tihi në... - 7 horas thë mãprario. Uko yai maro ĩxia mahirayou. (...) Wa toai tëhë... titiprai, huu tihini, ai thë pëni ai prea titiprai... uxi, xohorema, carvão napë wama wãha hirai, a yoprio tëhë, wa imiki no preai, kuwë yaro... huu tihini, imiki no pree, moyamiikini. Titia hurakini, tanaya hĩkaa

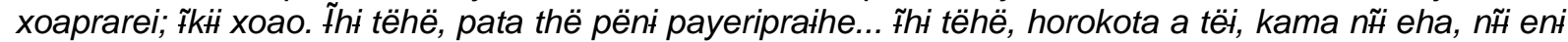
a pouwei tëni, axi titia xoakei - xapono hweha hami? -; xapono hweha hami, prahai hami mai, sipo hami mai; mi amo yai ha. Axi titia hurakini, titia hurakini... ah! huraa totihiprarini; sako si axi prea hẽha totihiprarini; axi kõa xoamakei. Îhi tëhë, axi komakei tëhë, axi thaa xoakei, axi yaua xoamakei... Kama a rĩa xuhurumou pëha; fnaha thë pë thai. İhi tëhë, huu tihi ka kii, tihi yaakei, ĩximaihe. Yuu puxi pei a rë yaarëni thaka thakini, pei a hoyamakei...thë mĩsi këki prakei. Yuu puxi, xi yopi ha, mahuku uprakei tëhë, mahuku kõmi tarerayou yaro. T̃hami thë pë ahetamoimihe; oxe thë pë huu: "Ma! Mihami, hu no mai!", thë pë kuu; mamiki hõximarayou, thë pë pihi kuu yaro. Ĩnaha thë pë kuaai. 
"Apesar disto, podemos realizar um reahu mesmo se não houver morto. Se houver muita banana podemos fazê-lo à toa. Não choramos, os convidados simplesmente retornam para casa. Fazemos por fazê-lo, à toa. Na estação da pupunha, por exemplo, mesmo se não houver cinzas mortuárias, realizamos o reahu só por fazê-lo. O mais freqüente, no entanto, é no caso de morte..." ${ }^{\text {"60 }}$.

Geralmente, as cinzas de um homem adulto e de certa importância na comunidade podem ser motivo para a realização de mais de um reahu-geralmente dois ou três - a intervalos de um ano cada. A primeira cerimônia é realizada em sua própria aldeia, as outras nas de seus aliados - que tomaram para si parte das cinzas do morto e com ela a obrigação de realizar a cerimônia.

As cuias uma vez entregues, dá-se por terminado o rito de cremação. Começa então a preparação dos alimentos que serão distribuídos e consumidos durante o reahu. A caça provirá da expedição coletiva levada a cabo pela comunidade do morto, e o resto - mandioca, banana, cana-de-açúcar etc. - será colhido nas roças da comunidade, sobretudo - mas não somente - na do celebrante principal e nas da parentela do morto. Quando as bananas já estão a ponto de serem colhidas, parte-se então para a caçada coletiva, que pode durar pouco mais de duas semanas. As mulheres, se o desejarem, também podem acompanhar seus maridos na expedição de caça.

\footnotetext{
${ }^{60}$ Transcrição em yanomami das palavras de Morzaniel Iramari, watorikitheri: Ĩha, pora axi thaa huraa hikiprareihe tëhë, kama nĩ e xĩro îkï; nï e xĩro ĩkï xoao. Îhi makii, heri e, kama aĩpë e pree ĩkï. İkï xoati. Ai pë xĩro Ĩkï maprario - si yarei... si yakei tëhë, thë pë xĩro ĩkï mãprario. Hapa, yaai maohe

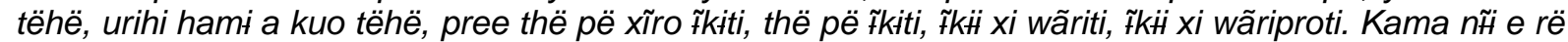

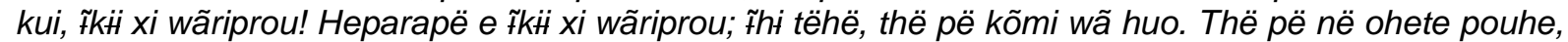
thë pë pihi wãriprao. Kama a kuaaiwei, thë pë pihipraihe tëhë, thë pë pree ĩkï. Axi thaprareihe tëhë, thë pë îkii kõtaimi. Thë pë f́k̈̈ kõtaimi makii, axi maprou tëhë, thë pë xĩro f̃k̈̈ kõo; axi maprou tëhë. Kõmi thë pë r̃kï kõrayou! Pei axi rĩa mãpramapehe; thë pë reahumou ahetou; thë axi maai, kõmi thë

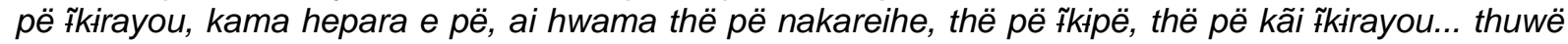
pata, warõ pata, ai ha praha rë aĩpiwei, thë pë íkirayou; a rë pihipouwehei, thë pë kõmi îkirayou hwama pë makii. Kuwë yaro, yamaki xoayou. Yamaki mi xoayou pëoimi. Îhi thë no wãha yamaki xĩro xoayou. Îhi thë mao tëhë, yanomae nomaiwei thë mao tëhë, yamaki reahumou pëoimi. Ĩhi makii, yamaki mii prea reahumou pëowei thë kua. Ai koraha ki mi thaprai, yamaki mi reahumou përayou; yamaki ̃̂kiimi, yamaki xaari kopohuru. Yamaki totihi ĩkii mii, xuhuru mii kõ pihio tëhë, yamaki reahumou pëo. Raxa pë kuo tëhë, pora axi mai ha, yamaki prea reahumou pëo. Yamaki reahumou pihio mao tëhë, pora axi pëha yamaki xĩro reahumou. Pora axi mao tëhë, festa yama a thai xi wãriproimi. Teteee xĩro thai; tete mahĩ thapraihe, pora axi kuo tëhë. Axi kuo tëhë, ai thaa kõprareihe, ai thë pë nakai kõo, ai thë pë nakai kõo; três festas xĩro kuprario. Rope mahĩ mai! Um ano thë kuprario, seis meses, si axi maamareihe...
} 
Somente os membros da comunidade do morto participam da caçada:

"os que desejamos convidar, com os quais queremos dançar, estes de forma alguma participarão do hwenimou",

esclarece Morzaniel Iramari. Logo nos primeiros dias na floresta, os caçadores preparam e consomem yekuana, a droga alucinógena que abre caminho aos hekura, para que estes propiciem sucesso no empreendimento. As carcaças dos animais abatidos vão sendo moqueadas para que a carne se conserve e, para isto, os caçadores contam com a ajuda preciosa dos jovens e das mulheres que os acompanham e que guardam os acampamentos enquanto eles perambulam pela mata à procura de animais. Sem a ajuda destes últimos, a caçada tomaria muito mais tempo, pois os caçadores teriam que se reversar entre a caçada propriamente dita e o preparo e guarda do moquém.

Como poderíamos prever, a escolha da presa é feita de maneira criteriosa e sistemática pelos caçadores que participam do hwenimou. A anta, Tapirus terrestri, o maior animal terrestre da Amazônia, podendo chegar a pesar mais de 150 quilos e medindo cerca de dois metros de comprimento por um de altura, é a presa preferida dos Yanomami no hwenimou e constitui também a marca de uma caçada bem sucedida. Outros animais, porém, são sistematicamente procurados e devem necessariamente estar presentes como caça cerimonial (hweni): o macaco guariba, Alouatta ursina; a galinácea mutum, Crax alector, o macaco-aranha, Ateles belzebuth; o macaco-prego, Cebus nigrivittatus, o porco-do-mato, Dycotiles tacajuyarima, e também o queixada, Tayassu pecari. No entanto, em determinadas regiões, como o Médio Demini, por exemplo, outros animais, se abatidos durante a caçada cerimonial, serão consumidos pelos caçadores e família ainda durante a caçada e não moqueados e levados para a aldeia; é o caso do jacaré, do tamanduá bandeira, do tatu, por exemplo. Estes não são considerados hweni (caça cerimonial) pelos Yanomami.

Outros fatores também podem influir na escolha da caça. Se a cerimônia não conta com a presença de convidados, por exemplo - e por isso mesmo é bem mais singela, praticamente não sendo considerada um verdadeiro reahu -, animais menos "nobres", como a paca, Paca virgata, ou o veado, Odocoileux virginianus, 
podem substituir a verdadeira caça cerimonial - mas desde que não haja convidados na cerimônia. E mesmo entre a caça considerada conveniente para a celebração do rito há uma certa hierarquia, em que a anta e o macaco-aranha estão no topo, seguidos, segundo creio, do mutum. Já o macaco-prego e o guariba não constituem o alvo primeiro das caçadas. Considerados como uma segunda escolha, só são aproveitados se não houver nada melhor ${ }^{61}$.

Como já foi dito, as mulheres e moços da aldeia também podem participar do henimou, caçada cerimonial, atividade que acaba mobilizando grande parte da comunidade, como nos conta Iramari:

"As mulheres também acompanham os que partem. Caminham um dia inteiro, dormem e, no dia seguinte, caçam; pernoitam novamente e seguem caçando. Somente os co-residentes participam da caçada cerimonial e nunca os visitantes! Só os membros da aldeia podem participar da caçada. Os que são convidados, com quem desejamos dançar não participam. Só nós caçamos para a cerimônia. Logo no início da caçada, consumimos yekoana e, então, discutimos e planejamos a caçada; quantos dias, para onde iremos. Geralmente, em cinco dias, obtemos caça o suficiente para a cerimônia funerária. Ela é então moqueada para que não se deteriore. Estando na floresta também discutimos sobre o que iremos preferencialmente caçar: -"Pois então, cacemos anta, macaco-prego, mutum, guariba... porco-do-mato, caititu", dizemos sempre, pois são estes os animais

\footnotetext{
${ }^{61}$ Nas palavras de Morzaniel Iramari: Thë pë arini, hwei thuwë thë pë nokamarohuruhe, thë pë ayohuru; mõri thë pë mikei. İhi tëhë, aa kôrayouwei; thë pë... yaro a niapehe thë pë miketayou. Yahitheri pë xĩro; hwama pë mai! Yahitheri yamaki xĩro, xĩro hwenimou. Yama thë pë rĩa nakaiwei, yama thë pë rĩa praiamayouwei. Yamĩ yama a rĩa niai pario. Ĩhi tëhë, yamaki kuo, kami yamaki kuowei kuprou tëhë, yamaki kuo tutekei tëhë, ĩhi tëhë yekoana pë thaihe, këki usumai; r̃hi tëhë, thë pë wã hai, yamaki nowa thayou kõo urihi ha: "Awei! Hwei wamaki... wama a tharei, wama thaa kõrei, wama thaa kõrei, wama thaa kõrei... cinco dias thë tiha kuprarini, thë ou tëhë, yamaki wehemai pario... yaro tarei maopë. "Urihi hami wamaki kurayou, ai wamaki kukei. Yaro wama pë...

Ai ani, yama thë pë nohi yai yaipouwei, ĩnaha thë pë kua - ז̃hi yamaki nowa thayou tëhë, yamaki kuu: "Weti yama thë pë yai tha, niapë tha?", yamaki kuu tëhë, "Awei! Wama a niaiwei, xama wama a niai, iro wama a niai, paari wama a niai, paxo wama a niat, yarima wama a kãi niai... poxe, warë pë xë. İhi yama thë pë nëhë yai yaii, yamaki henimou tëhë. Ai thë pë kii, yama thë pë niai makii, yama thë pë xawai. Iwa yama a tharei makii, haya yama a tharei makii, yama a warei; yama a arapoimi; thëpë yama a xëprarei makii... Urihi hami yama a xĩro warei; heni mai! Ĩnaha kami yamakini yama a thai: thëpë yama a arapoimi, opo yama a arapoimi, iwa yama a kãi arapoimi; yama thë pë waa xoatarei. Ai urihi hami thë pë aramaihe; kami yamakini yama thë pë aramaimi.

Rope yamaki reahumou tëhë - waĩsipë reahumou tëhë -, amotha yama xĩro arakei, haya a xë; innaha yama xĩro arakei. Ai yama thë pë nakai tëhë, f̃hi yama thë pë aramaimi. Innaha yamaki pihi kuu: "Haya a ka kii, a totihiimi hãtho, a hõximi hãtho; ai thë pëni a hõximi thaa hãthoaihe...", yamaki pihi kuu yaro, yama a niapraimi, wai xĩro. Paxo yama pë xĩro nëhë yai, paxo pë xĩro; paxo yama pë xĩro hëtëi. Yarima yama pë hëtëi mahĩimi makii, ĩhi mï tëhë, yama pë xĩro niaprai. Iro yama pë hëtëi mahĩimi makii, ז̃hi mï tëhë, yama pë xĩro niaprai.
} 
preferidos na caçada cerimonial. Caçamos outros, porém, ou são uma segunda escolha, ou simplesmente os comemos durante a caçada, já que não são considerados caça cerimonial. $O$ jacaré ou o veado, por exemplo, se matamos um durante a caçada, ele é simplesmente comido e não moqueado. É o mesmo caso do tamanduá-bandeira, que também não o moqueamos; o tatu também não é considerado caça cerimonial: se são mortos, serão consumidos ainda na floresta. Em outros lugares os yanomami os tratam como caça cerimonial, mas não nós. Se fazemos uma cerimônia às pressas, caçaremos paca e veado - somente essas duas caças. Mas, se convidamos gente de outras aldeias, não caçaremos esses dois bichos, pois pensamos que isto pode não ser bem visto pelos convidados. Então, preferimos sempre guariba, que é a caça mais procurada; se encontrarmos macaco-aranha, o flecharemos, mas será imediatamente consumido, como também será o caso do macaco-prego". ${ }^{62}$

A motivação, segundo os próprios Yanomami, vem da satisfação em ver suas presas abatidas como caça cerimonial, o que certamente reforça ou aumenta o prestígio do caçador. Outro fator vem da reprovação pública àqueles que podem ou devem contribuir para o sucesso da caçada e não o fazem. As recriminações recaem tanto sobre a preguiça do omisso quanto sobre sua atitude de desrespeito com o morto. O que acaba sempre provocando suspeitas de que, na verdade, o defunto era um desafeto seu e por isso não quer contribuir de maneira efetiva para o sucesso da cerimônia. Por isso, todos participam.

A caçada coletiva dura cerca de duas semanas. Enquanto isso, na aldeia, o clima é de festa, ou quase. As mulheres cantam e dançam todos os dias, quando não estão ocupadas na preparação dos alimentos para a cerimônia. Findo o henimou, todos os que participaram da caçada, homens e mulheres, se pintam antes de retornar à aldeia - os homens de negro, com genipapo, e as mulheres de vermelho, com urucu. $\mathrm{O}$ mesmo acontece com quem permaneceu no xapono: se

\footnotetext{
${ }^{62}$ Texto em yanomami: Yaro a hëtihe tëhë, ai thë hëaimi. Kõmi hiya thë pë huu. Kami yamaki ha, kõmi thë pë huu. Ai thë pë pihi motai xë, hëkei, mõri a; ai warõ huu pihi motai xë, hëkei. Warõ thë pë, thuwë pë, kõmi huu pihio tëhë, thuwë thë pë kõmi kãi huu. Thuwë pëni thë pë nokapou, thë pë rama huimi makii, yaromou thë pë payëripraihe wëyëi. Pei xirikiprai, pei yahikimai, pei yaximai, wamotima thë pë thai. Thë pë rama huu tëhë, thë pë ohuu yaro...
} 
pintam e embelezam com os melhores adornos que possuem. Já não se pensa ou se faz outra coisa além de preparar a cerimônia.

Ao chegarem, os caçadores depositam toda caça na residência daquele que possui a cabaça com as cinzas e promove a cerimônia - que, como vimos, geralmente é o pai, o filho ou o sogro da pessoa falecida. Os filhos do enlutado, se ele os tiver, o ajudam então na preparação da caça, principalmente cortando lenha e mantendo aceso o fogo do moquém - o que, em circunstâncias normais, é uma tarefa essencialmente feminina. Além destes, aquele que construiu o jirau em que o corpo do defunto ficou exposto na floresta, também tem a obrigação de auxiliar em todos os afazeres ${ }^{63}$.

Antes de entrar na etapa final do rito, é interessante notar que se as cinzas são tidas como "propriedade" dos homens - o celebrante principal e os secundários são sempre homens -, cabe, no entanto, às mulheres a responsabilidade de zelar pelas cabaças que as contêm, que devem ser mantidas próximo ao fogo, no calor, durante todo o tempo que precede a sua ingestão ou seu enterro. Sob a responsabilidade das mulheres ficam também os pertences ainda não destruídos do morto, como o estojo de caça e seus ornamentos, por exemplo, e o transporte das cuias durante as viagens (ver Biocca 1968:224, 315, 328; Albert 1985:425).

$\mathrm{Na}$ véspera da chegada dos caçadores que partiram em busca da caça cerimonial (heni), são enviados emissários à aldeia, ou às aldeias, que serão convidadas $^{64}$. A escolha das comunidades a serem convidada é subordinada à história da comunidade de origem e aos laços de parentesco no interior desta.

\footnotetext{
${ }^{63}$ Texto em yanomami: Hapenaha thë prea kua: a nomarayou tëhë, axi ka tapouni, a nomarayou tëhë, kamani a waximi paxira ahũ thakeiwei ani, r̃hi pëni a kãi payëripraihe. Hei a nomarayouwei, a wãximi kuo tëhë, ai yayo a huimaiwei, a paxarahũ [f̆hiraki] thaprareiwei, urihi hami a thaketayouweini, rnhi ani pei axi kuowei r̃hi a xĩro payeriprai. Thë dois a no thakei tëhë, kama axi thapopë hami thë payeriprai. Yayo a makini, payëriprai; kama a kĩaama kutaëni, kamani pora axi thaprarema yaro, kamani a hĩkema yaro, kamani uko maro toama yaro.

${ }^{64}$ Nas palavras de José Luís Góes Melo, Kohoroxitari, em yanomami: "Pë pë reahumou ahetou tëhë, të pë heniomi huoprou, yaro a tai mi huihe. Pë pë rë xoaiwehei, hanatomi pëni ihi pë wano pokoaihe".
} 
Durante esse tempo, o clima de festa já se instaurou na comunidade do falecido. Canta-se todas as noites, celebrando a abundância de alimentos e a chegada dos convidados.

\section{IV - O reahu e a ingestão das cinzas}

A chegada os emissários põe fim ao período de espera. Desde então, iniciamse os preparativos para a recepção dos convidados; a aldeia é varrida e limpa, o mingau de banana (alimento cerimonial) começa a ser preparado, o beiju de mandioca é feito e estocado, assim como a caça, que será moqueada durante vários dias. A entrada dos convidados no xapono é precedida por um diálogo cerimonial (hiimou) - realizado entre os mais importantes (geralmente também os mais velhos) da aldeia anfitriã e um convidado eminente -, em que os assuntos são a amizade entre os dois grupos, os laços que os unem, sua generosidade, a abundância de alimentos etc.

Um pouco mais tarde, os convidados chegam próximo ao xapono, se reagrupando nas imediações da porta principal, antes de entrar. Eles entram um por um, fazem a volta na praça central, dançando e fazendo gestos agressivos, como se quisessem flechar e matar os anfitriões - tudo sempre de uma maneira caricatural, teatral, intencionalmente cômica, que provoca risos e comentários entre os últimos. Depois de ter feito a volta completa, ao redor do praça central, passando em frente de cada morada, o visitante sai, dando a vez ao seguinte, que repete a mesma sequência. A cada entrada, o conviva é saudado por um coro de gritos e assovios, sustentado sobretudo pelos mais jovens.

Em seguida, é a vez das mulheres e crianças entrarem, dançando e tocando pequenas flautas de bambu. Depois disso, todos se reúnem no meio da praça central para concluir a apresentação. Após rápidas consultas, visando colocar os convidados entre aqueles com os quais mantêm melhores relações, eles são então conduzidos aos espaços domiciliares, onde os anfitriões Ihes dão comida e tabaco ${ }^{65}$.

\footnotetext{
${ }^{65}$ Descrição recolhida de José Luís Góes, em yanomami: "Ihi tëhë, pë pë kõkaprou, hama komi tëpë kukeyoriï, heha ha. Përiomi pëni pë kai haihe, pë kai rukëaihe, kama pë hatopi nahi ha. Nii pë itapou mi paohe, pee nahe kai hipëakeihe".
} 
O fim do dia dá início às libações de mingau de banana. Trata-se, de fato, de uma verdadeira peleja alimentar, em que os participantes, enfrentando-se dois a dois, se esforçam por fazer o adversário beber a maior quantidade possível do mingau enquanto cada um procura, de seu lado, beber o máximo sem passar mal. As analogias com um duelo ou com um combate são evidentes pelas palavras proferidas e pela mímica que é utilizada:"Pë pë xëyou, kurata ukinn’", "eles se batem, através do mingau de banana".

Certa vez, durante a visita a uma aldeia distante, a dos Hoaxipokokaopëteri, na Serra do Gurupira, cujos habitantes preparavam então uma pequena festa, o convite para participar das libações me deixou francamente embaraçado. Para dizer a verdade, a visita não fora muito bem vinda e o clima estava francamente tenso, especialmente entre meus acompanhantes yanomami ${ }^{66}$. Ademais, esperava-se a chegada tabém dos Toxamoxiteri, da Venezuela, que, segundo diziam, certamente com algum exagero, se nos encontrassem ali, nos matariam a todos. A certa altura um dos membros da aldeia dirigiu-me a palavra num tom marcial: "Napë, pëhëki xëyou ta xoao!", "Agora, vamos nos bater, estrangeiro!". Hesitante, pensei que me tinha metido em uma situação delicada e que dificilmente escaparia a uma confrontação física mais ou menos violenta com meu anfitrião. O mal-entendido só foi dissipado quando um yanomami que me acompanhava na viagem percebeu meu equívoco, explicou-me a metáfora - ele se referia a um "duelo de mingau" e não de socos ou bordunadas - e tirou-me do embaraço.

Esse "duelo alimentar" dura horas e, depois de vomitar várias vezes, com um mal-estar insuportável causado pelo consumo excessivo, anfitriões e convivas

\footnotetext{
${ }^{66} \mathrm{Na}$ verdade, alguns dos yanomami que me acompanhavam, haviam participado também de uma expedição promovida pelo governo venezuelano, pela CCPY e Funai, no primeiro semestre de 1998, com o objetivo de mapear as aldeias yanomami da bacia do Siapa e avaliar sua situação sanitária. $O$ quadro encontrado foi desolador: as comunidades não contavam com nenhuma assistência em saúde por parte do Estado venezuelano e apresentavam um índice de incidência de malária assustador. Por fim, ao término de um mês de caminhada e visitas, a equipe foi resgatada pela Guarda Nacional Venezuelana na aldeia dos Toxamoxiteri. No entanto, os grandes helicópteros utilizados na operação assustaram bastante os Yanomami. Para eles, a presença dessas máquinas voadoras gigantescas e fazendo um barulho estarrecedor foi a causa de uma epidemia entre os seus (provavelmente de gripe, que sempre acaba causando casos graves de pneumonia e que pode custar a vida de algumas crianças e principalmente bebês): prometeram então vingança aos yanomami que acompanhavam os forasteiros - ou seja, os mesmos que visitavam a aldeia dos hoaxipokokaopëteri comigo. Ora, eles também eram convidados para participar da festa que ocorria; por isso, o clima tenso e a relutância do velho líder em permitir que pernoitássemos em sua aldeia.
} 
empanzinados não são mais capazes de se manter de pé e se sentam pelo chão ou se estiram nas redes. É então a vez de mulheres e crianças, cuja contenda é mais moderada.

A noite é marcada pelo wayamou, um diálogo cerimonial, ritualizado, mais ou menos cantado, que se desenrola na praça central do xapono entre visitantes e anfitriões. O wayamou é reservado somente aos homens, geralmente - mas não exclusivamente - aos mais velhos, que, sucessivamente, se acocoram par a par, um diante do outro, enlaçando o pescoço de seu parceiro com um braço, e se engajam no diálogo. Seu conteúdo versa principalmente sobre os fatos importantes que dizem respeito às relações entre suas comunidades, ou às relações entre brancos e yanomami na região, ou ainda simplesmente às entre as comunidades, como por exemplo, as alianças, as guerras, as trocas de bens etc. (ver Biocca 1968: 218, sobre um exempolo de conteúdo de um diálogo mantido por Fousiwë, um dos maridos de Helena Valero).

Lizot, que ressalta a importância para o homem yanomami de dominar esse ritual, descreve o wayamou:

"Ao cair da noite, um visitante lança a fórmula do convite, um anfitrião se aproxima e lhe responde. $O$ visitante desce de sua rede para se por em face de seu parceiro e se lança com ele em um atordoante duelo verbal, um vai-e-vem incessante de frases, curtas e destacadas, ditas para um e repetidas pelo outro." (Lizot 1976:238)

Os dias seguintes são ocupados pela preparação dos alimentos cerimoniais o mingau de banana, mas sobretudo a caça moqueada, o heni, e os beijus de mandioca - que serão distribuídos aos convidados na despedida. Na verdade, a distribuição de alimentos representa um dos momentos fortes da cerimônia; reahumou, verbo yanomami que pode ser traduzido por participar do reahu, a festa comunitária, e quer dizer também distribuir alimentos. A regra parece ser a de provocar a penúria na comunidade anfitriã; não the deixar quase nada para comer depois da cerimônia. Aliás, um reahu que não seja o palco da mais ostentada abundância, e que, ao contrário, seja marcado pela escassez de alimentos, constitui um verdadeiro infortúnio para a comunidade anfitriã, podendo provocar críticas bastante virulentas da parte dos visitantes e pondo até mesmo em risco as relações entre as comunidades envolvidas. 
Assim, toda energia dos anfitriões é colocada a serviço da produção e preparação dos alimentos; a mandioca é colhida das roças em grande quantidade, transportada até o xapono, onde é descascada, cortada em pequenos pedaços e lavada, antes de ser moída e transformada em uma pasta que será prensada e, em seguida, cozida sobre placas - chamadas de mahẽ a e fabricadas, às vezes ainda, em argila cozida - colocadas sobre as brasas da fogueira. O preparo da mandioca pode tomar todo o dia e a noite, indo, às vezes, até a manhã do dia seguinte.

Durante as noites, as moças e rapazes que não estão ralando e prensando mandioca, dançam e cantam, marcando assim um outro tempo forte da cerimônia (Biocca 1968:220-223; Chagnon 1997 [1968]:164).

Pela manhã, continua-se a trabalhar na preparação da comida. No dia seguinte, o último da festa, a caça moqueada será repartida. A parte mais importante será dada aos visitantes, que a levarão para sua aldeia no dia seguinte.

Durante o dia, a carne moqueada é cortada, lavada e, em seguida, cozida em grandes panelas. Por fim, tudo (a carne cozida e os beijus) será repartido e colocado em grandes cestos e estocado no espaço familiar do celebrante principal, onde permanecerá até o dia seguinte. (Albert 1985:488-489) À tarde, o celebrante principal começará a preparar o epena, alucinógeno que será inalado coletivamente no dia seguinte, durante a ingestão ou o enterro das cinzas. No caso dos Yanomami orientais - que não ingerem necessariamente as cinzas mortuárias -, ele sustentará também um diálogo cerimonial (hiimou) com a pessoa que vai realizar o tratamento final da cuia funerária, caso se trate de um visitante.

Entre os Yanomami ocidentais, a ingestão das cinzas é precedida por uma apresentação dos homens mais jovens, que, portando arco e flechas, circulam em volta da praça central, de costas para o exterior do xapono, retesando e soltando a corda do arco, como se estivessem flechando. A cuia contendo as cinzas do morto é então aberta e os homens se reúnem ao redor do celebrante principal, como descreve Lizot (1976:231):

"Enquanto eles circulam, Kaõmawë pega a cuia que contém as cinzas de Sisiwë, morto pelos de Mahekoto, e a tinge de urucu. O selo de cera é desfeito. Então, os homens adultos chegam com suas armas e suas aljavas; eles permanecem em pé, serrados uns contra 
os outros; à direita, as mulheres vieram se sentar. Todos choram e cantam [...]".

As cinzas são então vertidas dentro de uma cabaça contendo mingau de banana, que é, em seguida, ingerido pelos parentes mais próximos e pelos aliados mais importantes. A cabaça é então quebrada e seus pedaços jogados ao fogo, onde também são finalmente queimados os bens do defunto que não foram destruídos anteriormente, como, por exemplo, os ornamentos, as pontas de flecha ou pequenos objetos, como anzóis.

Em seguida, na praça central do xapono, os jovens homens, anfitriões e visitantes, sopram nas narinas de seus parceiros - utilizando um tubo apropriado - e inalam uma quantidade impressionante do alucinógeno epena. Nisso, são acompanhados pelos mais velhos e, pouco tempo depois, todos os homens estão sob o efeito da droga.

"É nessa direção que, agora, se dirigem os homens, acocorados como patos, lançando sempre punhados de terra; percebe-se que eles reviram os olhos para o céu, mantêm os cotovelos afastados enquanto batem os punhos contra o peito e que a língua pende fora da boca, em um rito horroroso." (Lizot 1976:233)

No caso dos Yanomami orientais, na manhã do último dia, a droga é levada à praça central, onde os homens se reúnem para inalá-la em uma grande algazarra. É então que o celebrante principal leva até sua habitação alguns homens, dos quais um, o sepultador, será responsável pela execução da última parte do rito funerário, o enterro das cinzas. Na véspera, em uma operação marcada pelas lamentações e pelos choros, uma certa quantidade de cinzas foi colocada em uma cabaça menor. Os homens - entre eles, o sepultador, levando a cabaça numa bandoleira - se dirigem para a residência do celebrante principal, onde se agacham se apoiando nos ombros, marcando o tempo com gritos ritmados. As cinzas são então vertidas em um buraco cavado no local reservado à fogueira doméstica (Albert 1985:495-496). As cinzas de um homem adulto - em função de seu prestígio e pelo fato de sua morte exigir uma vingança exemplar, obrigando assim a comunidade a selar várias alianças -, podem dar origem a vários reahu, realizados em um período que pode se 
estender a uma década inteira. Assim, suas cinzas serão consumidas ou enterradas em várias cerimônias ${ }^{67}$.

Após a ingestão ou do enterro das cinzas, a manhã é marcada pelas frases curtas e sincopadas do diálogo cerimonial yaimo $u^{68}$. Mais tarde, a vingança sobre a comunidade inimiga acusada de provocar a morte será discutida e planejada. O que quer dizer que o plano de ataque e a ocasião da emboscada serão então decididos. Finalmente, se um consenso é alcançado, antes da partida dos visitantes, o rito watupamou também será realizado. Trata-se de um prenúncio às hostilidades entre os Yanomami; anuncia que, para a comunidade inimiga, o tempo do luto não tardará. É chegada sua vez...

Entre os Yanomami orientais, também registramos variantes no que diz respeito à conclusão do rito funerário. Somente as cinzas das crianças são consumidas: um pouco da cinza é vertida na palma da mão e ingerida acompanhada de mingau de banana. As cinzas de adultos não são consumidas - os Yanomami desse sub-grupo Ihes atribuem um poder patogênico que poria em risco a vida ou a saúde de quem as ingerisse ${ }^{69}$.

\footnotetext{
${ }^{67}$ Assim como o consumo ou enterro das cinzas, a destruição dos objetos do morto pode ser escalonada ao longo de anos, em vários reahu, quando se trata de um homem de prestígio. Os casos narrados na literatura acerca dos Yanomami bem como minha experiência levam a crer que enquanto houver algo das cinzas do morto, haverá também algum objeto seu, sendo sempre os derradeiros objetos destruídos no momento mesmo do consumo/enterro das últimas cinzas.

${ }^{68}$ Lembrando de uma visita que fez com Housiwë, seu primeiro marido, à comunidade dos Mahekototeri, Helena Valero reproduz o que este disse ao anfitrião, o velho Kachihewë, durante o hiimou: "Ehé... eu vim na sua casa, você que tem facões dos Brancos; dê-me um facão para que eu possa levá-lo comigo, pois tenho grande dificuldade de romper os troncos com meus próprios dentes para construir minha. Você que é amigo dos Brancos, você recebeu deles estes colares; coloque-os no meu pescoço para que as jovens moças digam: 'Ele foi onde há um amigo dos Brancos; no seu poscoço, ele porta um belo colar; ele também tem pendido nas orelhas algo muito bonito, ele também está se tornando um amigo dos Brancos" (Biocca 1968:218)

${ }^{69}$ De acordo com Albert (1985:498-509), os Yanomami ocidentais distinguem seis categorias de cinzas, com destinos diferentes:

1 - cinzas de crianças: ingeridas com um alimento cerimonial;

2 - cinzas de grandes guerreiros: são esfregadas sobre o corpo de crianças e jovens adultos;

3 - cinzas de adultos comuns: enterradas sob o local da fogueira doméstica;

4 - cinzas de xamãs: enterradas em local frio, durante uma cerimônia na qual se consome alimento;

5 - cinzas de mortos em epidemias: enterradas em local frio sem alimento cerimonial;

6 - cinzas de mortos em combate: espargidas sobre o solo.
} 
Os funerais são, assim, precedidos por uma série de ritos e seguidos por outros tantos. O reahu envolve, com efeito, tantos ritos diversos que poderia ser considerado como quase todo o conjunto de atividades rituais yanomami. Quem já teve a oportunidade de assistir a um reahu, teve certamente a impressão de que trata-se sobretudo de uma grande comunhão, de um festival da socialidade yanomami, certamente a epifania de sua vida social, momento em que a vida da aldeia extrapola os seus próprios muros e afirma a necessidade de buscar de todas as maneiras estabelecer os laços com o exterior. Assim, podemos avançar que são os rituais e as cerimônias ligadas à morte que constituem o operador maior das interações sociológicas da vida comunitária yanomami.

Em última instância, é no interior dos rituais que decorrem da morte que se atualiza a vida social e política yanomami: é dentro do seu quadro que a rede de alianças é reforçada, que é lembrada a pertença a uma mesma comunidade de origem, um entre-si, e que os limites dos nós estabelecem no mesmo momento aqueles que dele estão excluídos, os outros, dos quais deve ser cobrada a dívida do sangue vertido. Articulando, finalmente, deste modo, os dois eixos sobre os quais repousam as interações com o mundo exterior à aldeia: a aliança e a agressão, a paz e a guerra e que dão um sentido mais vasto à existência da própria comunidade, já que a liga ao que se passa do outro lado da serra, na outra margem do rio e ao que acontece além do horizonte.

"Rito único" no sentido de que, sendo múltiplo, contém em si praticamente toda a vida ritual yanomami, o reahu condensa também sua vida social e política. 


\section{Capítulo V - O outro eu, ou a pessoa yanomami}

"Xei! Hei maxita a rë kui ha, yamaki ha kuoni, yamaki no xĩro ohotai: harakani, ori këkini, xawarani, no wãrini"

"Querido! Aqui nesta terra, estamos sempre sofrendo. Seja por ponta de flecha, picada de cobra, doença ou ou por qualquer outro mal"

José Pirisitheri

á pudemos começar a vislumbrar nos capítulos anteriores um pouco da complexa teoria da pessoa yanomami; para eles, além de um corpo físico de carne e ossos, o ser humano é constituído de um interior imaterial ou cerne metafísico, composto, por sua vez, de dois elementos: uma imagem vital - que se transforma em espectro, pei a no porepi, na morte ou na perda de consciência - e um duplo animal. Esses dois elementos (que poderíamos considerar como presas privilegiadas por parte de predadores - humanos e não-humanos) representam o objeto da maioria das curas xamânicas.

Podemos admitir, como o fez Albert (1985:139), que a dicotomia entre corpo físico (biológico) e os constituintes metafísicos (ontológicos) do homem marca as representações yanomami da pessoa. Além disso, não é difícil reconhecer que a essa oposição se sobrepõe uma outra, entre o exterior e o interior do ser: assim, o corpo é designado por um termo que bem poderia ser traduzido como envelope, pele, superfície (pei sikt, siposikt) e o conjunto dos elementos imateriais são remetidos para um interior ( $m i$ amo, pei ũuxi).

De fato, a oposição cardeal que ordena o conceito de pessoa yanomami é a de interior e exterior. Assim, para os Yanomami, o ser humano é constituído de uma exterioridade física aparente, de carne e ossos, e um interior imaterial, ou cerne metafísico, formado, por sua vez, de dois componentes: uma imagem e um espectro; devemos também acrescentar a esses últimos um alter-ego, ou um duplo, 
geralmente animal, mas que, como veremos mais adiante, habita sempre bem distante de sua contraparte humana; e, por fim, a própria consciência (pei puhi).

De uma maneira esquemática, esses componentes metafísicos poderiam ser descritos como:

- uma alma (pei a no porepi), entendida - a exemplo do wakan achuar (cf. Descola 2006), com o qual, aliás, apresenta vários paralelos - como alento, o princípio da vida; por vezes também apontada como imagem (pei a no ũtupi), ou interior metafísico, que os yanomami partilham com todo ser vivo ou inanimado;

- um assim chamado duplo animal (pei norexi, pei a no rĩxi ou ainda nonoxi em sanumá), espécie de contraparte animal do homem. O rĩxi, como o chamaremos daqui por diante, não é somente, ou apenas, uma alma zoomorfa $^{70}$. Trata-se de um espécime animal que tem uma vida análoga à do homem a quem está intimamente vinculado, como veremos mais adiante. Além disso, espécies vegetais e até mesmo objetos, como panelas, por exemplo, podem também ser o duplo de uma pessoa.

- uma consciência (pei puhi), sede da volição e do pensamento/cognição e também das emoções, mas que tenderíamos muito mais a considerar como o predicado de um estado de equilíbrio e harmonia do ser humano.

Somam-se a esta lista outros espíritos que se pode adquirir durante a vida, mas que nos parecem - ao menos pelo momento - contingentes e de ocorrência limitada: o espírito humapi, que o recém-nascido adquire em um rito de nominação no qual o seu pai caça e abate um animal que transmitirá o espírito e o nome ao bebê; e as imagens vitais de seres (preferencialmente animais) que podem eventualmente residir no corpo de um yanomami cujas características e qualidades atraem essas imagens-espíritos.

\footnotetext{
${ }^{70}$ Embora costume ser assim descrito na literatura acerca dos Yanomami. Voltarei à questão do chamado "duplo animal".
} 
Por enquanto, vale a pena lembrar: primeiro, que o espírito humapi, apesar de apresentar algumas semelhanças, não é o rĩxi, o duplo animal, cujas características veremos mais adiante. Além disso, nem todos os yanomami possuem um espírito humapi, já que o rito de nominação não é sistematicamente praticado por todos, restringindo-se, pelo que sabemos, aos Sanumá; segundo, que as imagens vitais não devem ser confundidas com os espíritos auxiliares dos xamãs (os hekura). Sua estadia pode ser circunstancial e não requer nenhum aprendizado ou prática mística. Essas imagens simplesmente descem no corpo de quem demonstra as qualidades das quais elas mesmas são uma espécie de arquétipo. Assim, a imagem tihiri (da onça) irá descer ou dançar no peito do homem destemido (Albert 1985:157-156).

Vejamos agora, mais detalhadamente, os componentes da pessoa:

Pei a no porepi - Espectro que todo humano abriga no interior de seu corpo e que o deixa no momento da morte e durante os sonhos. Sede das manifestações não-conscientes e involuntárias da pessoa, tal como acontece no transe ou nos episódios de alteração de consciência devidos ao uso de halucinógeno ou à doença (Albert 1985:143). Assim, em tais estados, os Yanomami dizem que a pessoa está se comportando como pore, como um espectro. É o que apontam também para falantes de outras línguas que a yanomami, de quem dizem que são aka porepi literalmente: "[fala] língua de pore".

Esse espectro, quando deixa o corpo durante o sono, vaga pela floresta, ocupando-se tal como o faz um yanomami, procurando comida, visitando as roças (inclusive as alheias), consumindo bananas, principalmente, além de outros alimentos. Oportunamente, Albert (1985:143-146) aponta a associação que existe entre o sopro da vida e pei a no porepi: retornando de suas perambulações noturnas, essa alma entra no corpo quando bocejamos (ou seja, inspiramos) e, no fim da vida, o deixa quando se expira o último sopro, o que nos faz aproximá-la do karõ krahó (cf. Carneiro da Cunha 1978) ou da wakan achuar (cf. Descola 2006). A respeito deste último, os Achuar acreditam que

"o wakan deixa o corpo pouco antes da morte para se transformar num Iwianch que irá assombrar a casa até a completa dissolução das carnes do defunto" (Descola 2006:411). 
Essa partida do wakan faz com que o moribundo já seja tratado como um morto ${ }^{71}$, mesmo que ainda esteja consciente e mantenha todas as suas funções vitais, pois a morte é vista sobretudo como um processo social e biológico, como se dá entre os Yanomami. Assim, é bastante corriqueiro ouvir que alguém morreu, mesmo que trate-se de uma perda da consciência ou um de algum estada mórbido agudo.

Mas é preciso distinguir pei a no porepi da imagem também abrigada no interior de cada um - nas suas profundezas, como dizem os Yanomami. Trata-se da imagem vital de todo ser vivo, pei a no ũtupi, núcleo dinâmico da vida, que veremos mais adiante e que alguns associam ao próprio pei a no ũtupi, sendo seu centro ativo. Por ora, basta dizer que a alma está para o corpo como a imagem vital está para a alma, ou ainda, que o coração está para o corpo assim como a imagem vital está para a alma - aliás, não raramente coração e imagem vital são associados pelos Yanomami, que vêem o primeiro como a sede desta última.

Ademais, o imperativo de se apagar todo o traço que possa lembrar a existência de um morto é explicado por uma dupla necessidade: primeiro, a nostalgia, a profunda melancolia e a cólera que incita a lembrança de sua existência; segundo, a extinção dos vestígios de sua existência terrestre permite ao espírito do morto (pore a) se desligar do mundo dos vivos e ir mais depressa para o dos mortos. A eliminação das lembranças compreende também o nome do morto, que nunca mais deve ser pronunciado por seus parentes e amigos. As cinzas consumidas, pore torna-se o pei a no porepi (ver supra, páginas 108-110), como bem explica Helena Vallero. Ouçamos suas explicações:

"Eles chamam Poré o espírito das pessoas que morrem; eles o temem. Dizem sempre que o ouviram assoviar na roça, bater nos troncos. Eles correm ver e não há ninguém; é pore que fez o barulho, concluem. Ás vezes, escuta-se tossir na floresta, alguém cortando madeira, plantas caírem, crash... vá-se ver e não há nada. Enquanto as cinzas não forem consumidas inteiramente pela família no mingau de banana, Poré ou Poreana, com seus olhos de fogo, erra pela noite. É a alma que fica neste mundo para proteger as

\footnotetext{
${ }^{71}$ Descola relata o caso de uma velha achuar, que, durante seus últimos dias de vida, já era tratada como morta pelos seus parentes próximos: "Você está morta, vovozinha, está morta', diziam-Ihe tristemente, enquanto ela ainda falava e pedia de comer" (Descola 2006:409)
} 
cinzas; ela só partirá quando as cinzas dos ossos forem consumidas. Eles dizem às crianças: "Não se afastem, não vão sozinhos à roça, caso contrário, Poréana os atacarão". O poré daqueles que se perdem e que morrem sem ser queimados e sem que suas cinzas possa ser ingeridas continuam errando" (Biocca 1968:121-22).

No entanto, Pore, além de designar de uma forma genérica todo espectro, fantasma que assombra o cotidiano yanomami - principalmente na floresta, assustando e perseguindo quem anda só - é também uma figura mítica de grande importância para os Yanomami ocidentais (conhecidos também por Xamathari). Pore, ou Poreawë, foi quem Ihes mostrou a agricultura. No início dos tempos, os antepassados dos Yanomami, para acompanhar a carne de caça, resignavam-se a comer terra. Mas foi Poreawë quem Ihes revelou a existência das bananas e ensinou-lhes a roçar a terra e cultivá-las (Lizot 1989:80-87).

Pei a no ũtupi - A palavra ũtupi significa imagem, desenho, sombra etc., mas a expressão pei a no ũtupi tem um significado preciso: trata-se da imagem vital, do princípio fundamental de toda existência (Albert 1985:146; Chagnon 1997 [1968]:113) está presente em tudo o que existe. Como já dissemos, é o cerne da alma e, talvez por isso mesmo, mais vulnerável à predação; qualquer atentado a sua integridade ameaça mortalmente a pessoa:

"A maior parte das afecções têm assim sua patogenia interpretada em termos de atentado - segundo modalidades e agentes variáveis - à imagem vital da vítima" (Albert 1985:150).

Assim, a maior parte das curas xamânicas tem por finalidade recuperar a imagem vital de alguém:

"The close association the Yanomamö make between 'soul loss' and sickness is best exemplified in the shamanistic practices of the men. They spend several hours each day, if they are shamans, chanting to their tiny hekura spirits, enjoining them to either attack the souls of enemies or help them recover souls lost by people in their own village. This is a constant battle, and the men take hallucinogenic snuff - ebene - daily to do contest with their enemies through the agency of their personal hekura" (Chagnon 1992 [1968]:114).

Mas o próprio xamanismo yanomami pode ser resumido a uma manipulação cósmica de imagens vitais de todo o tipo: 
"Assim, os xamãs têm o poder de invocar (de fazer descer - itomai, de fazer dançar - praiamat) as imagens vitais de todo ser, entidade ou objeto que deseja fazer intervir em sua prática" (Albert 1985:14647).

$\mathrm{Na}$ verdade, os espíritos auxiliares dos xamãs, os hekura, podem ser pensados como as imagens vitais dos seres do plano do mito, que coabitavam nos primeiros tempos com os ancestrais dos Yanomami. Como explica Albert (1985:147), se desejamos nos referir à imagem vital de um animal qualquer, basta acrescentar o sufixo -ri ao seu nome; por exemplo, se trata-se da imagem vital da onça, thihi, diz-se tihiri. Ora, da mesma maneira são chamados os espíritos auxiliares.

A imagem da pessoa morta é também apontada como responsável pela situação de perigo por que passa o matador durante o ritual unokai; ela está sempre à espreita de qualquer deslise por parte do homicida - como a transgressão de alguma proibição alimentar, por exemplo - para fazê-lo adoecer e tirar-Ihes a vida, conforme diz Lizot (1996:112) ${ }^{72}$ :

"Surtout, le principe vital (pei mi amo ou pei no uhutipt) de leurs victimes les oppresse e peut mettre leurs jours en péril".

Pei a no rĩxi (pei norexi) - Ao nascer, cada yanomami tem seu destino ligado ao que foi conhecido até agora como uma espécie de alter-ego animal ou duplo animal, pei norexi ou pei a no rĩxipë. Porém, como já mencionamos, espécies vegetais cultivadas e até mesmo objetos manufaturados podem também constituir esse componente da pessoa humana; o que nos desautoriza a chamá-lo estritamente de duplo-animal - como tem sido geralmente chamado.

$\mathrm{Na}$ verdade, ambos, o yanomami e seu rĩxi, nascem ao mesmo tempo e a vida de um é o espelho da do outro, terminando também simultaneamente. No entanto, os dois nunca devem se encontrar durante suas estadias nessa terra, já

\footnotetext{
${ }^{72}$ Ademais, Lizot vê uma diferença entre a interpretação dos Yanomami orientais, analisada por Albert (1985) e a dos Yanomami ocidentais. Estes, de acordo com Lizot, consideram pei a no uhutipi, o princípio vital, como um centro imaterial, uma energia que continuaria existindo mesmo após a morte, independente do corpo físico. Ao contrário, para os Yanomami orientais, o princípio vital é associado ao sangue, e devorar o princípio vital de uma vítima seria o mesmo que ingerir seu sangue (Lizot 1996:114).
} 
que o rĩxi, que é não somente de uma espécie animal, mas também um espécime, vive necessariamente distante do yanomami ao qual tem sua existência vinculada geralmente, nos limites da floresta conhecida, onde moram os inimigos deste. Mesmo se esse duplo animal é espacialmente dissociado do indivíduo, tanto os Yanomami quanto os etnólogos tendem a considerá-lo como um dos componentes do corpo e/ou da psique ${ }^{73}$ humana (Albert 1985:150; Chagnon 1997 [1968]:113; Ramos 1990:191-92). E não poderia ser de outra forma, conforme veremos.

O duplo rĩxi tem a mesma aparência e comportamento do animal de que porta o nome. Mas alguns yanomami lembram que são sempre de cor bem mais clara, branca, "como o algodão". Deste modo, um rĩxi onça será, como seu análogo animal, um predador (Albert 1985:153). Quando um homem vai à caça, seu rĩxi também vai, quando dorme, seu duplo faz o mesmo, estabelecendo assim uma espécie de vida em duplicata. Ora, a morte de um dos pares implica, como já dissemos, a morte do outro. Então, se, em terras longínquas, um caçador desconhecido mata seu rĩxi, o seu par yanomami inelutavelmente perecerá. E este é um dos diagnósticos de causa de morte recorrente entre eles. Portanto, caçar animais pode também significar caçar gente, na medida em que as presas abatidas podem ser rĩxi de outros homens e mulheres que, por sua vez, habitam regiões distantes.

Um fato torna esta contraparte animal do homem ainda mais intrigante: é seu modo de transmissão. O homem o herda de seu pai e a mulher, de sua mãe. Os rĩxi masculinos são repertoriados, em geral, mas não exclusivamente, entre os animais que voam ou vivem nas copas das árvores, enquanto os femininos são seres aquáticos ou animais que rastejam ou vivem em tocas dentro da terra. A respeito de seu interlocutor yanomami, Chagnon escreve (1992 [1968]:113):

"Kąobawä, for example, has the black spider monkey, basho, as his alter ego, which he and all his brothers inherited from their father: 'We are the basho mashi!' they would say, the 'lineage' of the spider monkey".

\footnotetext{
${ }^{73}$ Ou seja, ou fazendo parte da estrutura psíquica do indivíduo ou ainda remetendo a seus componentes espirituais.
} 
O que foi dito merece alguns comentários. Mashi quer dizer coletivo, parte, denotando assim alguma forma senão de parentesco ao menos de identidade compartilhada. Quando Kąobawä afirma que é do grupo dos basho, podemos ter a impressão que enuncia seu pertencimento a alguma unidade sociológica da vida yanomami, como, aliás, sugere o próprio Chagnon: "the 'lineage' of the spider monkey". Não se trata disso. Desde há muito, deixou-se de lado a discussão sobre a existência de linhagens entre os Yanomami, questão a que já fiz alusão no capítulo I. A dificuldade ou o contra-senso de se elaborar e manter um saber genealógico diante do tabu dos nomes próprios e, sobretudo, o dos mortos; a inexistência de qualquer função (regular casamentos etc.) ou papel sociológico dessas supostas linhagens - que, diga-se de passagem, eram sempre entrevistas, apenas vislumbradas - acabaram por colocar um ponto final nesse debate, que, aliás, como já dissemos, caracterizou essa primeira fase da etnologia das terras baixas, quando ainda tentava-se adequar dados amazônicos - às vezes, às custas de muito malabarismo - a modelos etnológicos de outros continentes.

Resta que a existência desse duplo-animal, essa espécie de totemismo sexual, como o definiu Albert (1985:156), continua a ser um intrigante elemento de reflexão para a etnologia e mais especificamente para a etnografia dos Yanomami. Sabe-se que está fora de questão atribuir-lhe qualquer relação com classes matrimoniais ou regras exogâmicas, como já concluía Lizot (1984:112):

"les animaux-emblèmes ont pu servir dans le passé à déterminer des classes matrimoniales, mais l'impression qui predomine actuellement est que le rituel et les croyances correpondant au noreshi s'affaiblissent".

Ora, não é só isso: sua distribuição por sexo (transmissão paralela) exclui qualquer conexão entre os rĩxi e linhagens exogâmicas (classes matrimoniais) em um sistema, como é o yanomami, de trocas matrimoniais restritas (Albert 1985:119, 156).

Sabe-se também que, sob nenhuma hipótese, os Yanomami consomem a carne de seu animal-rĩxi. Como nos esclarece Morzaniel Iramari, da comunidade Watoriki, no Amazonas, que, vale a pena sublinhar, também aponta pássaros e abelhas como rĩxi femininos: 
"É assim: as filhas têm o mesmo rĩxi da mãe. Por exemplo, quati. No entanto, não há só quati, existem vários outros: arara, veado, anta, jibóia, panela de barro... Quando a mulher tem o rĩxi arara, os yanomami não comem esse pássaro, pois é o seu próprio rĩxi. Se for veado, se a mulher tiver o rĩxi veado, também não o consome; tartaruga também não, se for 0 caso. Não conseguem ingerir tal alimento, sentem ânsia. É assim. Têm medo: "Não! Não como, não consigo; tenho medo. Não é comestível!", dizem. Quando mulheres têm rĩxi-abelha, por exemplo, não consomem mel ${ }^{774}$.

Finalmente, os Yanomami atribuem aos rĩxi uma certa ascendência sobre o caráter da pessoa, além de conformar seus traços físicos, conforme as características do seu par, como mostra Albert (1985:152-153), relatando as descrições yanomami:

'Lorsqu'elle possède um double animal tapir une femme est très grosse, son épiderme est lisse, foncé; lorsqu'il est doté d'un double animal aigle harpie (Harpia harpya) un homme est généralement de complexion claire, de petite taille et ses arcades sourcillières sont proéminentes; lorsqu'une femme a pour double animal un cervidé (Mazama americana) ses jambes sont longues... elle est grande... ses yeux sont clairs; lorsqu'un homme a pour double animal un singe hurleur il va courbé en avant... il est de haute taille... ses cheveux ont des reflets roux".

Conforme podemos reparar, os rĩxi femininos citados pelos informantes de Albert correspondem, geralmente, à categoria de animais terrestres (anta, veado) e os masculinos, à dos animais que voam ou habitam as copas das árvores (macaco guariba, gavião...). Vale a pena lembrar que essa relação "espacial" é também presente no cotidiano: a rede em que dorme o homem é sempre amarrada no alto e a da mulher embaixo, bem como a porção feminina do espaço familiar é a parte contígua à parede externa da casa coletiva, ou seja o local mais baixo do teto, ou, em uma relação concêntrica, as mulheres se colocam na periferia ou nos limites do círculo que descreve a maloca e os homens estão situados no meio, na medida em

\footnotetext{
${ }^{74}$ Texto em yanomami: Rĩxi thë ãha, ĩnaha thë kua: rĩxi pë ka kii, hapenaha thë pë kua: thuwë a ka kii, kama thëë e pë xo, thë pë kua paxia. Thë pë ka kii, huão-huão pë ãha kua. Ĩhi makii, huão-huão pë kua xaariimi. Thë pë nikere kua: ara a kua, haya a kua, xama a kua, hokotho këki kua, hapoka kua... Thuwë ara a kuo tëhë, yanomami thë pëni ara pë kãe waimihe, kama a rĩxi kutaeni. Haya a makii, kama thuwë haya a rĩxi kuo tëhë, haya a kãe waimi; totori a kãe waimi, kama rĩxi kutaeni, a rĩxi kua yaro. Thë pë kahiki kiri, thë pë haro moxi yoruu. İnaha thë pë kua. Pë kirii: "Ma! Ya waimi. Ya kirii; thë wamou hõximi!", thë pë kuu. Thuwë a, puu a kuo tëhë, puu upë kãe waimi.
} 
que a praça central é o espaço masculino por excelência, onde as cerimônias xamânicas são sempre realizadas.

Não obstante, essa correlação espacial — homem:animais que voam ou vivem nas alturas::mulheres:animais terrestres e aquáticos - não é sistemática: a anta, por exemplo, pode ser o rĩxi tanto de homens quanto de mulheres; a jibóia (hokotho këkt) me foi apontada como rĩxi masculino. Além disso, para minha surpresa, várias plantas cultiváveis também podem compor o rĩxi dos Yanomami: 0 inhame, a batata doce, a mandioca. As plantas-rĩxi, no entanto, não são encontradas nas roças, mas na própria floresta. $E$ mais: elas também brincam, balançam suas folhas e ramagens, caçam e perambulam pela floresta. Pelo que pude apurar até o momento, somente as mulheres têm rĩxi vegetais.

Os Yanomami também atribuem uma grande perspicácia e agilidade aos rĩxi, o que os torna uma presa difícil - mas certamente não impossível - para os caçadores, como me ensinou o velho sexagenário Esmeraldo, da aldeia de Arakohithë-u, na Serra Parima, em Roraima, no verão de 2003:

"Se caçadores yanomami se aproximarem e perceberem o rĩxitamanduá, mesmo bem próximo, no nível do chão, outro rĩxitamanduá gritará para alertá-lo: "kopouuuu!" Claro que os caçadores gostariam de flechá-lo, de matá-lo, mas ele seguramente mergulhará no rio. O rĩxi-tamanduá yanomami se lançará nas águas. Não! Certamente, não morrerá. É muito astuto, quer continuar vivo. Ele mergulhará, se esconderá na água. Pois é! Não se mata tão fácil, não se deixa morrer à toa. Quer viver: "Não! Não me deixo matar", ele retruca. Desaparece nas profundezas do rio, onde mergulhou. Depois, quando os yanomami já se foram, se mostrará novamente. São espertos, muito espertos". ${ }^{75}$

\footnotetext{
${ }^{75}$ Texto em yanomami: Hwei, ai yanomami a huimai, ai a huimai, huimai... taaiha... a tararei tëhë, yatoto mahi ha, hwei ai ximi thë wãri yaua kutou tëhë: "kopouuuu!", a kutario. Wa xëprai pihioma makii, pei uha a kekei. Ximi a yanomami rĩxi kekei - ma! Nomaimi. A moyamimou ha; temi pirio pihio yaro. A kekei a hõyakei, maũ uha. Awei: xëomi, xëomi, xëproimi. Hũhi, temi piriowei: "Ma, kami ya xëomi!", pihi kuuwei.

A xi wãrikei, pei uha. Awei, u ũxi hami, pata u ũxi hami, a kekei. Waiha, yanomami a ma koõraa hurawei tëhë, a xĩro wawëtoa kõprario. t̃hi pë moyami, rĩxi pë moyami, pë moyami mahi.
} 
Um aspecto importante a ser ressaltado é que a agressão sofrida por um rĩxi em terras longínquas, causando necessariamente um estado mórbido no yanomami ao qual está ligado, pode suspender de maneira radical a rotina de sua comunidade, cuja normalidade é então posta entre parênteses e todos seus membros são envolvidos na luta pela recuperação do bem-estar da pessoa atingida. Na verdade, o processo de cura mobiliza toda a comunidade, ou pelo menos boa parte dela - ao contrário do que acontece com uma agressão à imagem vital, por exemplo, que costuma envolver apenas um xamã e o doente. Outra coisa importante: o espaço onde se dá a recuperação da pessoa afetada não é no centro do xapono, local de realização das curas xamânicas, mas, ao contrário, longe dele: é na floresta que se busca a cura, ou melhor, é a própria fuga através da floresta que é o remédio para o mal.

Assim, para defender um membro da comunidade que sofre em razão de um ataque a seu rĩxi, os habitantes do xapono devem deixá-lo e fugir para a floresta, onde só então - enfatizam com bastante insistência os Yanomami - o doente pode ser curado. Alguns yanomami da comunidade de Porapi, na bacia do rio Parima, em Roraima, certa vez, me contaram também que, nestes casos, eles devem procurar um curso d'água, onde se banham coletivamente - adotando o mesmo estratagema dos próprios rĩxi quando em fuga, conforme nos esclarece Esmeraldo, o ancião de Arokofithë-u:

"Nós Yanomami fugimos à noite. Yanomami que tenha rĩxi gato-domato, segue dizendo: "Yao, yao!" É rĩxi masculino. Retruca, então, outro yanomami rĩxi gato-do-mato. "Yao, yao!", respondemos nós homens. As mulheres, por sua vez, seguem fazendo: "Õa! õa, õa, õa, õa...". Todos fugimos, quando se adoece por agressão ao rĩxi. Fugimos todos, pois desejamos continuar vivos; protegemos nossas vidas; por isso, fugimos. Então, seguimos pela mata fugindo, fugindo... Seguimos para bem longe, cada vez mais longe: só então [o yanomami cujo rĩxi fora agredido] estará curado, seu mal terá fim. Os xamãs também lançam um terrível vendaval na floresta distante para amedrontar e afastar os yanomami que perseguem o rĩxi ameaçado, para que este possa escapar. Quando então os yanomami fogem, os rixi, por sua vez, também fogem e conseguem escapar. É assim que fazem acontecer os xamãs. Quando sofremos por causa do rĩxi, é assim que seguem fazendo os xamãs em seu ritual: "paaxi! paaxi! paaxi!", durante a nossa fuga através da floresta. Se a pessoa não se curar, proseguimos fugindo; se ainda não 
melhorar, continuamos a fuga. Se mesmo assim continuar doente, vamos para outra direção. Só então curar-se-á. Diremos então: "Sim, agora se curou. O vento causado pelos xamãs amendrontou os Yanomami que perseguiam seu rĩxi! Tiveram medo"76.

Duda, um xamã da aldeia de Hakoma, a poucos quilômetros de Arokofithë-u, também nos esclarece como se dá essa fuga, acrescentando mais uma medida tomada para proteger a pessoa em risco: as flechas são mordidas. Conta ele:

"Todos temos rĩxi, por isso sofremos quando eles são flechados por outros yanomami que vivem onde estão nossos rĩxi... Quando fugimos, estamos assim acompanhados: o irmão mais novo, o mais velho e o pai; são esses que fogem pela floresta quando temos o rĩxi flechado por outros yanomami. Quando o rĩxi é agredido e foge, sofremos por causa disso e também fugimos. Quando o estado do yanomami cujo rĩxi foi flechado se agrava, quando ele fica muito doente, mordemos as flechas; por sua vez, os rĩxi fazem o mesmo na floresta. Seguimos, então, mordendo as flechas; se não recobrar a saúde, continuaremos fugindo para mais longe. Aí então, a pessoa que sofre curar-se-á. Quando estiver sarado, retornaremos para casa. Agindo assim, mesmo tendo o rĩxi flechado, não permanecemos por muito tempo doente; logo recobramos a saúde"77.

\footnotetext{
76 Texto em yanomami: Yanomami yamaki titi tëhë, yamaki tokuu ha... ai yamaki ka... ãha kua hekurumasi kua hetua, ai si... hekurumasi, hekurumasi... Awei! "Yao...yao..." warõ a, warõ rĩxi a. "Yao, yao!", yamaki kãyo kuu. Warõ a. Ĩnaha... hïhi! Thuwë pë xio ka... kihami, thuwë pë: "Õa! õa, õa, õa, õa...", pë kuhuoru. Yamaki kõmi tokua haurayou, yamaki rãkaamou tëhë. Yamaki tokua haurayou. Yamaki temi pirio pihiowei; temi noamaiwei thë kutaëni... thë kutaëni. Yamaki tokua haurayou. Ĩhi tëhë, yamaki tokuai, yamaki tokuai. Kiha, yamaki tokuai, ai hami yamaki tokua kõa kõrayou: harorayou, a rãkamou maprario. Xapori thë pëni... ãha...a niai... a niaiwehei, thë pë... urihi pë ha, xapori thë pëni watori a kãyo thapramaihe, watori a... a temi pirimapou pihiowei thë kutaëni. Watori a thamareiwei, rihi tëhë, yanomami nëhë... rĩxi a nëhë mohotiprario, tokurayou, tokurayou. Watori a nëhë kiriri ha!Yanomami thë pë tokuu tëhë, rĩxi a tokua heturayou, inaha xopori thë pë, thë pë thaamaihe. Siomou tëhë, thë pë thaamaihe; t̃ha thë pë nëhë rëaihe: "paaxi! paaxi! paaxi!", tokupë hami nëhë rëai kuaihe, nëhë rëai kuaihe; haroproimi, tokua kõrayouwei; haroproimi, tokua kõrayouwei; haroproimi, yapaa kõrayouwei. Haroproimi, ai xomi hami, kua kõrayouwei. İhi tëhë, a xĩro harorayou. "Awei, a harorayoma, watorini, watorini, yanomami thë pë kirirarioyoma... yanomami thë pë kirirariyoma", yamaki kuu.
}

77 Texto em yanomami: Kami yamaki rĩxi kua yaro, kami yamaki rĩxi kua kutaëni, yamaki siyomou tëhë, urihi hami, yamaki rĩxi kuowei, ai yanomami thë pëni, yamaki rĩxi përiopë hami, yamaki niapraihe tëhë, kami yamaki rĩxini, yamaki... yamaki... urihi hami... aĩwë, hapeinaha yamaki kure (yamaki warõho yaro): hei, pë heparapë e, ai e, pë aĩpë e, pë fũ e, einaha yamaki rĩxi, urihi hami, yamaki kua yaro, yamaki niapraihe tëhë, yamaki tokuu, urihi hami.Rĩxipë tokuu tëhë, kami yamaki, kami yanomami yamaki, yamaki siyomou tëhë, yamaki tokurayou. Yamaki ha tokuruni, a nomaa mahirayoma makii, xaraka yama a wëtï. Rĩxipëni pë wëtï hetuaihe, urihi hami. Xaraka yama a wëtï kuaai, yama a prapoma makii, a haroproimi; yamaki tokua praha mahia kõrayowei, [îhi tëhë] a xĩro yai harorayou. A harorayo tëhë, yamaki kõa kopei. Ĩhi tëhë, yamaki rĩxi niapraihe tëhë, yamaki haririatimi, yamaki temitou xoa. 
O que diz o xamã Duda merece alguns comentários. Foge-se entre iguais do mesmo sexo: pai, filhos e irmãos; mãe, filhas e irmãs - o que nos remete ao modo de transmissão do rĩxi: de pai para filho e de mãe para filha. Aliás, foge-se da mesma maneira que se vive, pois os rĩxi - em uma espécie de segregação por gênero - convivem sempre entre, de um lado, as linhas masculinas e, do outro, as linhas femininas ${ }^{78}$. Como vimos, nesse percurso através da floresta, que é declaramente concebido pelos yanomami como uma fuga, eles devem imitar o som característico de seus respectivos rĩxi:

"De acordo com o rĩxi de cada um, nós os Yanomami imitamos o seu som característico enquanto seguimos fugindo. Os que são rĩxi gatodo-mato, rugem como tal; os que são macaco-prego reproduzem o seu som; os que são anta, fazem o mesmo, assim como os que são rĩxi-gavião. Assim agimos, nós homens, enquanto fugimos" ${ }^{\prime 79}$.

A glosa yanomami a respeito estabelece uma relação entre a fuga do rĩxi, perseguido por caçadores inimigos, a uma ação análoga de sua contraparte yanomami - garantindo assim a simetria existencial entre os dois seres: "se, ao contrário, eu permanecer enquanto meu rĩxi estiver fugindo, não recobrarei a saúde", argumentam os Yanomami. Justificam também que se agem assim é porque seus antepassados já o faziam desde há muito, como argumenta Duda:

"Assim como faziam nossos antepassados, fugimos para a floresta onde recobramos nosso bem-estar. Deste modo, nos curamos; se não o fizermos, nos matarão, seremos mortos; se nossos rĩxi não fugirem, se agirmos de maneira irresponsável, aí sim, morreremos certamente" ${ }^{\prime \prime 0}$.

\footnotetext{
${ }^{78}$ Nas palavras de Duda em yanomami: Kami yamaki rĩxi kua yaro, kami yamaki rĩxi kua kutaëni, yamaki siyomou tëhë, urihi hami, yamaki rĩxi kuowei, ai yanomami thë pëni, yamaki rĩxi përiopë hami, yamaki niapraihe tëhë, kami yamaki rĩxini, yamaki... yamakt... urihi hami... aĩwë, hapeinaha yamaki kure (yamaki warõho yaro): hei, pë heparapë e, ai e, pë aĩpë e, pë fĩ e, einaha yamaki rĩxi, urihi hami, yamaki kua yaro, yamaki niapraihe tëhë, yamaki tokuu, urihi hami.

79 Texto em yanomami: Kama pë rĩxi kuopënaha, kama pë ha owëmamoni, thë pë pree tokuu, yanomami thë pë, kami yamaki. Ai a hekurumi siki kuowei, a hei-heimou; yarima a kuowei, a yarimamou; xama a kuowei, a xamamou; koikoiyoma a kurenaha, rĩxi a kuo hwetuowei, kama thë pë ã kurenaha a pree kuu, a tokuu tëhë. İnaha warõ yamaki pree kua kua.

80 Texto em yanomami: Pata thë pëni, pata thë pë hapa tokuu kuapënaha, yama thë tapou yaro, yamaki tokuu, urihi hami, yamaki nëhë temi pëo. Yamaki harou; yamaki tokuu mao tëhë, yamaki xĩro nomaa mahipramaihe, yamaki rĩxi tokuu mao tëhë, yamaki pihi mohotimou tëhë, yamaki xĩro nomai. Inaha thë kua.
} 
O exemplo do que estamos tratando me foi dado no verão de 2004, quando visitei a comunidade Porapi, na região da Serra Parima. Quando cheguei à aldeia, ela estava deserta. Mas como a viagem fora longa e demandara muito investimento, decidimos permanecer lá até que alguém aparecesse, nos perguntando o que teria motivado tal ausência - não é comum os moradores abandonarem totalmente a aldeia onde moram e isso geralmente só acontece por um motivo bem grave.

Depois de alguns dias, os porapitheri foram chegando e, então, soubemos o que se passara: uma afecção na perna de um jovem yanomami (mais tarde diagnosticada por nossa medicina como osteomielite), foi interpretada como resultado de uma agressão sofrida por seu rĩxi; toda a comunidade então deixou a aldeia e passou a vagar pela floresta durante alguns dias na tentativa de curá-lo. Como seu estado não melhorava - ao contrário, continuou se agravando -, duas outras alternativas foram apresentadas pelos xamãs, um dos quais era o seu próprio pai, e pelos mais velhos: ou tratava-se de uma agressão por espíritos maléficos (no $w a \tilde{r} r)^{81}$ ou sua pegada (deixada em suas caminhadas através da floresta) teria sido tomada por desafetos de uma aldeia vizinha e enfeitiçada, possibilidade apontada como a mais provável.

Certa feita, um yanomami me explicou que, durante a fuga, são os rĩxi dos filhos do yanomami atacado que mordem as flechas que atingiram o pai, para ajudálo a se livrar delas.

A implicação existencial entre o yanomami e seu duplo é recíproca, pois não só o fato de o rĩxi ser flechado ou morto põe em perigo a vida do yanomami, como também o estado de saúde deste expõe seu rĩxi a sérios riscos, como nos esclarece Duda: se o yanomami adoece, o mesmo acontece com sua contraparte, tornando-se então visível aos caçadores, que podem assim matá-lo mais facilmente ${ }^{82}$. Ora, como já vimos, em estado de equilíbrio, normalmente o rĩxi não é avistado com facilidade pelos caçadores.

\footnotetext{
${ }^{81}$ Penso que a tradução mais precisa seria: agentes patogênicos sobrenaturais; já que a expressão só ocorre quando se trata da etiologia de uma doença.

82 Texto em yanomami: Yamaki hariri-hariri tëhë, xawarani yamaki kãyo xëi tëhë, xawarani yamaki kãyo haririmou tëhë, rĩxi pë, urihi hami, thë siyomou mi hetuai tëhë, pë wawëi tëhë, pë xëpraihe. Pë xëpraihe...
} 
Por outro lado, diversas vezes também ouvi dizer que quando os rĩxi brincam e se divertem - o que, ao que parece, é muito comum - tornam-se igualmente mais visíveis, mais facilmente descobertos. Isto também me foi confirmado por Esmeraldo:

"Quando brincam, quando dançam, os rĩxi tornam-se muito visíveis; ficam bastante aparentes quando dançam. Mesmo assim, sempre brincam muito na água corrente, onde moram. Os rĩxi vivem também em grande número" ${ }^{\prime 3}$.

Finalmente, Taylor afirma que, pelo menos entre os Sanumá, é comum as pessoas terem mais de um rĩxi; ele dá como exemplo um líder da aldeia Kadimani, que tinha uma harpia e outra águia menor "para o braço", um walali, que ele não identificou, um macaco-coatá, uma ariranha, um macaco-prego e um grande felino de espécie desconhecida! "A sogra de seu irmão mais novo tinha uma teia bara, um cachorro-do-mato, uma cobra grande e uma onça grande (azola bara)", descreve Taylor, acrescentando que mesmo as crianças podem ter mais de um rĩxi e vão adquirindo outros ao longo da vida (Taylor 1996:128).

Uma das conseqüências deste fato, segundo Taylor, é que mesmo que um dos rĩxi da pessoa seja perseguido e morto por um caçador, isto poderá não ser suficiente para causar sua morte, mas talvez uma grave enfermidade. No entanto, nosso autor acha que se um sanumá perder seu principal rĩxi, ele morrerá. De minha parte, nunca ouvi falar entre os Yanomami ou Yanomamë que alguém pudesse ter mais de um rĩxie tenho a impressão de que isto ocorre somente entre os Sanumá.

Aliás, encontramos também entre esses últimos, um outro duplo - desta vez, realmente animal - da pessoa, trata-se do "espírito humap", adquirido durante o nascimento da criança. Creio ser essa outra particularidade exclusiva dos Sanumá, não encontrada nos demais subgrupos yanomami. Este espírito, no entanto, constitui-se em vários aspectos um contraponto do rĩxi, sendo, na verdade, um desdobramento invertido deste último.

\footnotetext{
${ }^{83}$ Texto em yanomami: Thë pë îriamou tëhë, praiai tëhë, rĩxi pë wawëto mahi! Wawëto mahi yaro, ĩhi praiai tëhë, waoto mahi! Îriamou mahi, maũ u ha pë kuopë ha, pë îriamou mahi! Warõho thë pë kuopë ha, rĩxi pë... awei!
} 
O recém-nascido adquire seu espírito humapi - que quer dizer "cóccix" em yanomami e é denominado assim porque é pela parte inferior da coluna vertebral que ele penetra no corpo do bebê - através de uma presa abatida pelo pai durante uma caçada realizada imediatamente após o nascimento. Ramos (1990:244) conta que, na verdade, a razão manifesta para esta caçada é a de se obter um nome para o recém-nascido: ele será assim nominado em referência ao animal abatido. Este não deve de maneira nenhuma ser consumido pelos pais da criança - que devem inclusive evitar de tocá-lo:

"Quando nasce a criança, o pai vai à caçada ritual, em busca do animal cujo espírito será dado ao recém-nascido. Se tiver sorte, encontra o animal apropriado, mata-o, amarra-o num pacote de folha, evitando ao máximo ter contato direto com ele, e leva-o para casa" (Ramos 1990:245).

O animal é dado a um parente dos pais e é consumido sem nenhum problema como qualquer outra caça.

Mas se, por um lado, tudo parece levar a crer que se trata de um rito de nominação, por outro, vemos que nem toda criança sanumá recebe seu espírito humapi e ganha deste modo seu nome de infância. Ramos chega mesmo a afirmar que talvez somente o filho mais velho deva receber o "espírito do cóccix", ou ainda que, se uma criança da família já possuir seu epírito humapi, as outras podem prescindir de tal nominação. Além disso, pouco mais da metade dos recém-nascidos que recebem seu espírito humapi acabam não sendo nominados assim e ganham seu nome de outra forma.

O fato de ter seu "espírito do cóccix" não parece afetar a vida da criança sobremaneira e, como já dissemos, muitas delas não o têm. No entanto, as relações lógicas com o rĩxi - este sim, presente na vida de cada yanomami de todos os grupos - são marcantes. Ora, este último não só afeta, como também determina a vida de sua contraparte humana em uma espécie de simetria existencial. Ao contrário do espírito humapi, não é adquirido através da caça. Justamente, ao invés disso, espera-se sempre que não seja caçado, pois isto, como vimos, significaria a morte da pessoa. O rĩxi também não vive nas imediações de seu homólogo humano, mas onde moram os inimigos deste, agindo como uma espécie de âncora: 
prendendo a existência humana aos caprichos ou aos sucessos cinegéticos de seus imigos.

Creio que começamos a entrever a importância desse componente ontológico da pessoa yanomami e a necessidade de explorá-lo. Como vimos, trata-se de uma marca da condição humana; ser humano é dividir sua existência com um outro nãohumano - que está para nós assim como o hekura (um outro humano) está para os não-humanos.

Ora, uma das conseqüências lógicas da existência do rĩxi é que a caça pode ser vista também como uma modalidade de predação humana. E o fato de que os grupos longínquos podem ser apontados como responsáveis pela morte do duplo animal, e conseqüentemente, pela morte de membros de seu grupo, perpetua a animosidade e desconfiança entre os membros do grupo local e os mais distantes, conforme ilustra Taylor em seu relato a respeito dos Sanumá de Auaris:

"A única incursão guerreira de que tive notícia nos seis anos entre 1968 e 1974 foi em represália pela morte do nonoxi de uma mulher da aldeia de Azagoxi” (1996:129).

Ramos também salienta que para que a vingança ocorra - depois do diagnóstico dos xamãs apontando a aldeia responsável pela agressão - não é necessário que a morte no nonoxi tenha sido intencional ou não.

O rĩxi é um dos componentes da pessoa yanomami que ainda não foi devidamente explorado, e o que aqui proponho é apenas um começo possível de uma investigação que irá provavelmente revelar outros aspectos do que ainda não percebemos, por não lhe darmos a importância e atenção devidas. Sempre que os Yanomami falam do rĩxi, apresentam-no como integrando a categoria da presa por parte de um potencial inimigo, e nisso insistem bastante. A pessoa, desdobrada em dois corpos, torna-se duplamente vulnerável; o rĩxi lembra constantemente aos homens que sua existência não só se dá em um mundo onde os papéis de presa e predador são intercambiáveis, mas, sobretudo, que seu destino está preso ao de seus inimigos. E também ao de seus aliados, como parece indicar o caso que certa vez me ocorreu, de um pata que insistiu para que eu transmitisse aos nossos pata o recado de que eles, lá, estavam protegendo os rĩxi dos daqui, impedindo que fossem 
pescados (são trairões, dizia ele). Embora os Yanomami não falem espontaneamente do assunto, a não ser em caso de diagnóstico de doença, esse tema delicado merece mesmo maior atenção.

Passemos ao destino dos componentes da pessoa. Para além da morte, o que subsiste é um espectro cujo destino primeiro é a abóbada celeste, onde permaneceria por um determinado período. Após isto, o espectro, pei a no porepi, se transformaria em uma espécie de mosca - mõsiriwë ou mrõo sipë - que vaga pela floresta e se alimenta de carniça. Ao falarem a respeito, os Yanomami fazem questão de lembrar que tais seres alimentam-se de podridão, como se esse fosse mais um sinal da decadência que representam.

Smiljanic (1999:55) conta que, para os Yanomami da região de Toototobi, no Amazonas, os espectros dos mortos, pore pë, após ficarem um certo período nas aldeias dos mortos, transformam-se em moscas gigantes, e dirigem-se para o último nível do céu, tukurimamosi. Retornam, porém, mais tarde, para a terra, habitando florestas bem longe das que teriam morado em vida.

Para os Yanomami habitando a região da Serra Parima, em Roraima, mosiriwë, a mosca em que se transforma o espectro humano, desaparece nas profundezas da terra e morre, segundo algumas versões. Outras ainda dão conta de que esses insetos em que se transformam os espectros se metamorfosiariam ainda uma vez mais nas larvas kaxa, retornando assim do mundo subterrâneo para ter uma nova e efêmera vida na terra. Lembremos, porém, que as larvas kaxa são uma iguaria bastante apreciada pelo paladar yanomami - seu fim sendo, assim, na maior parte das vezes, o próprio estômago yanomami.

É como se a morte fosse uma extinção progressiva - de modo algum uma ascensão ou passagem para um plano superior. Mesmo o espectro em que nos transformamos - e que se transforma mais tarde em seres pouco dignos - ao fim de tudo também morre e desaparece definitivamente. Essa extinção se dá também no plano da memória coletiva. A dissolução da persona terrestre do morto yanomami não é o prelúdio à posterior constituição de uma nova persona na condição de ancestral, para usar os termos de Goody (1996:153). Na verdade, tudo é feito para 
que os vestígios que recordem sua existência sejam total e irremediavelmente apagados. Aliás, sua lembrança torna-se um tabu, cuja transgressão pode custar caro a quem o infringir. 


\section{Considerações finais}

"Nós estamos neste mundo para nos vingar; se a mim tu o fazes, a ti lhe farei"

Housiwë, namoweiteri

E NTRE OS YANOMAMI, temas que têm alimentado a reflexão no âmbito da etnologia ameríndia - como predação, alteridade, componentes da pessoa só surgem no discurso nativo quando o assunto é morte. De outro modo, não se mostrariam de forma alguma e sua existência passaria desapercebida. Ninguém fala a respeito de maneira espontânea. Se é de fato a morte a via de acesso privilegiada para compreendê-los, é preciso reconhecer que a glosa nativa a respeito dos assuntos a ela relacionados não é abundante - ao contrário, é sucinta e quase nunca voluntária; é preciso pois arrancá-la com muita habilidade e persistência. $O$ que não significa, evidentemente, que a matéria não tenha tanta importância para os Yanomami. Muito pelo contrário.

Acreditamos que é possível afirmar que, entre os Yanomami, é a morte que instaura a alteridade. Como? É ela que cria a diferença, delimitando o campo do outro, do inimigo. Sem a morte, a figura do inimigo - tão cara aos agenciamentos sócio-cósmicos da Amazônia - não passaria de uma virtualidade estéril, de uma potencialidade inscrita no mundo, de uma maneira geral, e nas relações entre as aldeias, de forma particular. É a morte que, por sua natureza, instaura efetivamente a alteridade tout court ou ainda a figura desse outro Eu que é o inimigo.

A primeira pista que me foi dada a respeito devo ao finado sogro de Davi Kopenawa, o velho Roberto Wanapitheri, da região do Alto Demini, no Amazonas, com quem, quando estava no posto da Comissão pró-Yanomami da região, tomava café todas as manhãs. Xamã reconhecido e temido entre os Yanomami, Roberto, curiosamente, não inalava yekuana para praticar o xamanismo: - "Não necessito! Bastam-me o tabaco e o canto", explicou-me certa vez. Era, contudo, um apreciador 
de café. Para nós dois, o copo de café de cada manhã era quase um ritual. Por volta das sete horas, Roberto sentava-se no pátio do posto e aguarda que lhe servisse um copo cheio de café; aí então, discorríamos sobre as notícias do dia: viagens à Boa Vista, visitas inesperadas, doenças, troca e aquisição de bens etc.

Certa vez, falando-me acerca da primeira humanidade, Roberto lembrou-me que Omami, nos primeiros tempos, ainda não existia. Os gêmeos surgiram a partir da morte de um yanomami, devorado por uma onça: a vítima do felino transformouse em Omami e Yoasi. Aliás, a cabeça se transformou em Omami, quando a onça a pôs no chão; Yoasi, por sua vez, surgiu das tripas, enterradas pelo animal. O resto do corpo foi devorado pela onça ${ }^{84}$. Mais tarde, notei que toda uma série de mitos também nos apontam a morte, ou sua proximidade, como a grande operadora através da qual o novo é criado, surgindo a diferença em um fundo em princípio não (de)marcado. Neste caso, a morte desencadeia a transformação, ou a alteração, essa noção capital da ontologia indígena.

Ora, no caso de nossos heróis, a morte que os produz é resultado de uma devoração. Ora, justamente, para os Yanomami, toda morte causada intencionalmente pela ação humana — ou seja, praticamente todas — é considerada como uma devoração. Matar é também comer, em uma linguagem crua que aproxima a figura do matador da do predador: para o yanomami que tomba em combate é dito que foi comido pelos inimigos: "A waremahe!"

Outro exemplo nos é dado pelo surgimento de Periporiwë, o hekura (imagem, espírito) Lua. Assim como no caso dos gêmeos, é a morte de um yanomami primevo que dá origem a Periporiwë: "Como hekura Lua desejava existir, um yanomami morreu para dar origem a Periporiwë", nos ensina um mito recolhido por Lizot (1989:103-05). Na verdade, nota-se que tudo se passa como se virtualmente

\footnotetext{
${ }^{84}$ Texto em yanomami: "Hapao tëhë, Omami a maoma makii; hapao tëhë, Omami a maoma makii, a kuo maoma makii, Omami... yanomae thë ha warini, irani, yanomae thë ha warini, irani, Omami thë kua xoaprarioma. Yanomae thë... yanomae thë omamiprarioma, irani thë ha warini. Irani ei! a ha warini, ei a yai ha haikiarini, ei a haikiarini, haikiarini, haikiarini, ei a xĩro ha prakini, pei he omamiprarioma. Naka he ha, maũ u weheha. Kiha, he a praa orakini; pei xiki, irani, a xiki patiripouwei, pei xiki Yoasi a paxiprarioma. Hapa, Omami a kuonimi. Yanomae, irani, thë ha warini, thë omamiprarioma".
} 
Periporiwë sempre tivesse estado lá, en creux, como diriam os franceses. Ele desejava sua existência, clamava por seu ser, antes mesmo de vir ao mundo - ou a este mundo.

É necessário, no entanto, que um yanomami morra para que então Periporiwë venha a ser. No caso da gênese de Periporiwë, no entanto, não há, de início, devoração, simplesmente ocorre a morte de um yanomami xamã (xapori). Contudo, é o próprio espírito Lua quem, mais tarde, em um ato considerado pelos Yanomami como abominável, irá comer suas próprias cinzas - ou melhor, as do yanomami que the deu origem. E ainda pior: isto acontece em seu próprio funeral! Uma vez incinerado o cadáver, Periporiwë retorna no dia seguinte e, esgueirando-se pela aldeia à noite, encontra suas cinzas que ainda esfriavam. O espírito Lua as devora sem nenhum pudor, provocando, assim, um barulho execrável, com os dentes a mastigar seus restos ${ }^{85}$.

Os parentes do morto consideram o comportamento de Periporiwë intolerável, além de um insulto sem precedentes: enfurecidos, perseguem-no a flechadas. Ele foge, então, para o céu na tentativa de se proteger das setas. Os Yanomami, frustrados por não conseguir alvejá-lo, chamam Suhirina, o hekura Escorpião, exímio caçador, que acerta sem dificuldade uma flecha no coração de Periporiwë. Do sangue derramado do Espírito Lua no chão da floresta, surgem os belicosos Xamathari. Em outras versões do mesmo mito, do sangue de Periporiwë surgem os próprios Yanomami.

A morte como evento criador da alteridade marca também o quadro das interações sociológicas yanomami: é o sangue vertido que faz surgir a alteridade, a figura do inimigo efetivo, nas relações entre as comunidades. Ocorrida a morte, é imprescindível que se aponte o responsável e se cobre dele o seu preço. Como disse o velho namoweiteri Housiwë, marido de Helena Valero, para seus anfitriões hasupiweiteri, que, segundo desconfiou desejavam dançar com as mulheres de sua comunidade para depois raptá-las: "Nós estamos nesse mundo para nos vingar. Se

\footnotetext{
${ }^{85} \mathrm{O}$ tema dos modos de comer associado a ruídos é recorrente na mitologia ameríndia, e largamente analisado por Lévi-Strauss nas Mitológicas.
} 
tu o faz a mim, a ti também Ihe farei!” (Biocca 1968:191). É a lógica implacável da vingança, mas que só faz sentido a na presença de um inimigo...

E é precisamente a morte de um dos seus que torna efetiva esta figura, como nos atesta mais uma vez o diálogo que Housiwë manteve com um outro anfitrião, Kachihewë, o velho líder dos Mahekototeri, de quem justamente Husiwë e os seus haviam tomado várias mulheres algum tempo antes:

"Não se inquiete, não; (...) não é por vingança, nem para fazer o mal. Eu os convidei só para o bem. Ninguém morreu e não estamos enraivecidos contra vocês" (1968:218).

Vemos que apesar do rapto das mulheres (que inclusive os Patanoweiteri ainda guardavam na ocasião da visita aos Mahekototeri), Kachihewë, no intuito de convencer seu convidado a respeito de suas boas-intenções, lembra-o que nenhuma morte resultou das relações entre as duas comunidades e portanto não haveria motivo para hostilidades.

Assim, antes do evento morte, a alteridade não passa de uma potência, uma possibilidade - talvez mesmo necessária do ponto de vista escatológico, mas ainda assim uma mera virtualidade - para uma dada coletividade, que, em última instância é o alvo da agressão sofrida; a qual, como sabemos, pode ser de natureza física, uma emboscada, por exemplo, ou xamânica, por parte de outra coletividade. Ora, isto significa também que o sujeito da violência, do ataque que resulta em morte, é sempre um sujeito coletivo, uma outra comunidade yanomami conhecida, na maioria das vezes. Estabelecido o laço entre a morte e a comunidade agressora, ela passa a ser para o grupo vítima de seus ataques o alvo da vingança que ocorrerá mais cedo ou mais tarde.

Vale frisar: não interessa se trata-se de morte "matada" ou "morrida" (esta distinção só faz sentido para nós); ou melhor, trata-se sempre e de apenas uma natureza: predação, agressão. Toda ameaça à vida, toda morte é, em última instância, resultado de uma investida, de um ataque: ou físico, direto, quase sempre da parte de outros yanomami, ou ainda através de uma agressão dos espíritos (hekura) geralmente enviados por outros xamãs - causa última da maioria das doenças ou de qualquer estado mórbido. 
É o que Descola chamou de "teoria do infortúnio", ou seja, todo acontecimento funesto é atribuído à malícia, à maldade de alguém, principalmente à dos xamãs inimigos. Assim, toda morte não-violenta torna-se suscetível de provocar represálias por parte da comunidade que se sente agredida. "O luto encontra na violência um exutório reconhecido e tinge a vendeta com sua paixão desesperada" (Descola 1993:177).

Quanto às doenças, velhas e novas que os acometem, não se pode dizer que os Yanomami não sejam capazes ou não estejam dispostos a reconhecer a nossa etiologia, com seu próprio repertório de agentes causadores de doenças - vírus, bactérias etc. Não demonstram definitivamente nenhuma relutância quanto a isso. Ao contrário, sempre espantou-me a facilidade com que aparentemente aceitavam diagnóstico e tratamento nos postos de saúde, apesar de os considerarem muitas vezes cruéis, principalmente no que diz respeito às crianças, espetadas por agulhas de injeção repetidas vezes. Do ponto de vista yanomami, embora muito eficiente, nossa medicina é também bastante superficial. Para o sistema yanomami, o fundamental é discernir causas últimas e próximas das enfermidades e estados mórbidos.

Se não resta dúvida que micro-organismos podem causar doenças - são tão invisíveis para o leigo quanto os hekura -, tampouco está em questão que a investida dos micróbios é motivada pela ação de algum inimigo; este sim é bem visível e a origem derradeira de todo mal. Trata-se de uma causa última, maior (ou social), da agência responsável pelo desencadeamento do processo de adoecer.

Não há, de fato, nenhuma incompatibilidade entre tratamento médico e xamânico - ao contrário, eles se complementam. Os Yanomami dispõem inclusive de terapias a base de ervas e substância extraídas de insetos, que são em geral responsabilidade das mulheres ${ }^{86}$. Por outro lado, presenciei muitas vezes o fato de,

\footnotetext{
${ }^{86} \mathrm{O}$ conhecimento das plantas de valor medicinal é mesmo extenso entre os Yanomami, como demonstra o etnobotânico Milliken:

"Um levantamento inicial feito na aldeia de Watoriki entre 1993 e 1994 revelou o conhecimento de pelo menos 113 espécies de plantas e fungos medicinais nesse grupo [...]. Outras pesquisas na região de Xitei em 1995 mostraram 109 espécies medicinais [...]. Dados adicionais colecionados durante uma visita breve ao Balawaú chegaram a um total de 198 espécies" (Milliken et Albert 1999:87)
} 
sempre que possível - e tolerado pelos agentes responsáveis pela aplicação de nossa medicina -, o tratamento médico ser acompanhado pelo xamânico, sem o menor inconveniente. Não resta dúvida, entretanto, que há uma hierarquia entre as duas terapias, sendo a xamânica a imprescindível; as terapias tradicionais à base de ervas e insetos, foram quase que totalmente substituídas pela nossa medicina, sempre onde esta é disponível.

Mas a presença insistente do xamã no leito do enfermo é sempre o sinal de que o seu estado é resultado da agressão de que é vítima e de que os seus estão a par e vigilantes. No entanto, se o doente se recupera e recobra a saúde, na maioria das vezes, o caso encerra-se ali. Talvez a comunidade agressora sofra, por sua vez, uma investida xamânica da mesma natureza por parte da comunidade alvo de sua própria agressão, mas não será alvo de vendeta. As relações entre os dois grupos podem ser abaladas por isto, mas não rompidas. Os membros das duas aldeias vão se evitar e manter, na melhor das hipóteses, uma indiferença hostil. Mas ainda assim, nada de irremediável irá acontecer impedindo que o tempo faça o rancor e a desconfiança desaparecerem.

Um exemplo, para mim bem representativo disto, foi o caso da comunidade Hayasiki, no Alto Demini, Amazonas, nos anos 1990. Atraídos para e pela instalação do posto avançado da Comissão Pró-Yanomami, os hayasikiteri se aproximaram da região do igarapé Hoahikatëopë-u (um pequeno afluente da margem esquerda do alto Demini) e, em meados da década, construíram uma grande casa coletiva em frente ao posto já construído e ao qual queriam dispor de um acesso ilimitado - o

No entanto, durante os dez anos em que estive entre eles - não só entre os Yanomami do Alto Demini, mas também entre os da Serra Parima, em mais de 50 aldeias, não me lembro de ter visto um yanomami utilizar remédios tradicionais para tratar algum doente. Quando levantava questões a esse respeito, na maioria dos casos, a resposta era evasiva e desinteressada: "não temos!" ou "os velhos é que sabiam; nós não sabemos mais nada disso!" Realmente, só os mais velhos tinham ainda algum conhecimento válido e os vazios demográficos, provocados pelas epidemias que dizimaram as gerações passadas, são responsáveis pela desaparição desses conhecimentos. Por outro lado, uma nova geração de líderes, que perceberam a importância dada pelos napë à preservação de suas práticas tradicionais, fazem alarde, em seus discursos, dos poderes da medicina tradicional yanomami, se queixando, ao mesmo tempo, do abandono em que se encontra sua prática entre os yanomami. Fazem também críticas a sua gente - a meu ver, justamente -, por aderir sem reservas à medicina ocidental, atitude, segundo afirmam, responsável pelo desaparecimento da medicina yanomami. 
que viam como uma retribuição merecida ao investimento que fizeram participando dos trabalhos de construção das suas instalações e da abertura da pista de pouso. Esta comunidade fora uma das que me acolheram logo quando cheguei à Terra Indígena Yanomami e com a qual me relacionei por um longo período de maneira muito estreita, o que me permitiu conhecê-los razoavelmente. Os Hayasikiteri habitavam antes bem mais a noroeste, nas serras da cadeia de montanha Gurupira, e sua rede de relações se estendia para a bacia do Alto Orinoco (Hara-u), na Venezuela.

A iniciativa de se implantar no igarapé Roahikatiopë-u - para os hayasikiteri, uma grande oportunidade de ter acesso aos bens manufaturados, armas de fogo, munição e mesmo assistência à saúde — foi vista como uma intolerável ousadia por parte das comunidades que já habitavam a região e custou aos Hayasikiteri o preço da antipatia geral. Porém, como era um grupo muito mais numeroso que os outros - contando com mais de 70 pessoas, quando a média da região estava girando em torno de 20; além disso, contavam com muitos homens adultos; ou seja, poderia reunir muitos combatentes se fosse necessário - eles puderam se manter ali durante alguns anos, suportando a hostilidade velada das outras aldeias. Já vimos também que as tentativas de estabelecer laços de aliança com os grupos locais não resultaram frutíferas.

Finalmente, quando um incidente, uma luta de borduna com membros dos grupos rivais, resultou na morte de um de seus - justamente o filho mais velho do líder -, tudo mudou de maneira irremediável para os Hayasikiteri. Na mesma noite da morte, o grupo incendiou a própria aldeia, e, prometendo vingança, abandonaram a região, refugiando-se na cabeceira do Orinoco, do outro lado da fronteira, na Venezuela. A morte de um dos seus tornara o que era virtual, somente uma tendência latente, em uma situação de fato: os Hayasikiteri passaram a ser inimigos jurados dos outros grupos em geral, e, em particular, dos Koherepiweiteri, responsáveis diretos pelos golpes que tiraram a vida do rapaz.

É bem verdade que a relação entre os Hayasikiteri e as outras comunidades presentes desde há muito na região do Roahikatiopë-u não era um exemplo de amabilidade, desde que os primeiros, abusando de sua força, oriunda da superioridade numérica, não só se impuseram na região como também pretenderam 
monopolizar os benefícios do posto que se instalara lá. Mas enquanto não houve derramamento de sangue, a situação foi suportada por todos, inclusive pelos próprios Hayasikiteri. Isto durou até dezembro de 1996, quando o jovem perdeu a vida.

Muitos anos depois, os responsáveis pela morte foram alvo da vingança prometida. Uma velha koherepiweiteri foi flechada e morta em uma emboscada próximo à roça de sua aldeia. Ninguém viu os atacantes, mas todos os indícios rastros, pegadas etc. - levavam à região onde então habitavam hayasikiteri, próximo à cabeceira do Orinoco, do outro lado da Serra do Urucuzeiro, divisor de águas entre o Brasil e a Venezuela. Esta fora a segunda e bem-sucedida tentativa de cobrar a dívida de sangue. A primeira, somente alguns meses depois da morte do hayasikiteri, fracassara: somente algumas flechas foram atiradas contra 0 xapono dos koherepiweiteri - coincidentemente quando uma equipe de filmagem do projeto Vídeo nas Aldeias estava lá.

Interessante lembrar que, após sua partida, os Hayasikiteri passaram a ser apontados como os responsáveis por todo episódio grave de doença e mesmo das mortes ocorridas entre os seus inimigos. Foi o caso do velho Roberto, wanapitheri, que, com a idade bastante avançada - tinha mais de 80 anos -, morreu em 1998, provavelmente de câncer, segundo nossa medicina. Na época, não faltaram acusações contra os Hayasikiteri, acusando-os de serem os causadores da morte do velho xamã. Por outro lado, curiosamente, começaram também a surgir boatos dando conta de que vários hayasikiteri teriam morrido, por causas as mais diversas, sendo a principal, no entanto, a picada de cobra. Essas mortes eram então atribuídas aos xamanismo agressivo e à feitiçaria dos próprios membros das comunidades do Roahikatiopë-u, inimigas dos Hayasikiteri.

Assim, vemos que, uma vez diante da morte, não resta aos Yanomami outra alternativa senão a de por a máquina escatológica em marcha, não só re-unindo uma coletividade dada e, no rito funerário, confirmando entre os seus a solidariedade em torno de um mesmo destino, mas também e sobretudo atualizando seu mapa de alteridades. Nele, novos inimigos são assinalados, ou ainda reinscritos antigos, com quem um inexorável acerto de contas se dará mais cedo ou mais tarde, o que atribuirá, finalmente, um sentido retrospectivo à morte, trazendo, desta 
maneira, seu apaziguamento. O evento morte se apresenta então para uma comunidade yanomami como a marca, como o resultado da onipresença de uma alteridade incontornável, da qual não se pode escapar.

Antes de continuar, porém, é preciso sublinhar que, no "sistema" yanomami, como dissemos, o alvo último da agressão que provoca a morte - por doença ou flecha, tanto faz - não é a pessoa, mas a coletividade, representada pela comunidade da qual o morto fazia parte. É a aldeia que se sente atacada, e o ritual funerário reforça ainda mais esse sentimento. Assim, como era de se esperar, os agressores são identificados, antes de mais nada, como membros de uma aldeia inimiga, que será então alvo da retaliação.

Pelo que sempre testemunhei, a identidade da pessoa sobre a qual recairá a vingança não tem tanta importância, desde que, claro, seja mesmo membro da aldeia inimiga e, de preferência - mas não exclusivamente -, um homem adulto. A dívida de sangue é cobrada da comunidade visada, não de uma parentela, família ou qualquer outro grupo. O quadro é bem similar ao dos Jivaro, onde, segundo Descola (1993:178-79), ao contrário do intercâmbio material ou matrimonial, que envolve dois ou mais indivíduos, a "troca de mortos" toma, desde o início, uma dimensão coletiva:

"Ce mécanisme d'extension est encore plus net dans le cadre de la vengeance d'un homicide, qui peut s'exercer indifféremment sur tous les membres proches de la parentèle de l'assassin par tous les hommes de la proche parentèle de la victime".

Mas se entre os Jivaro o pagamento da dívida de sangue pode ou podia ser feito através de um fusil, o mesmo não ocorre entre os Yanomami, para quem o desfecho necessário à uma morte não pode ser senão outra morte entre os culpados da primeira. Além disto, se é a negação de uma troca, de um intercâmbio voluntário, como a recusa da troca matrimonial, por exemplo, o que causa conflito entre os Jivaro, tal não parece ser o caso entre os Yanomami, pois, como vimos, os conflitos envolvem quase sempre grupos de comunidades que não mantêm (ou não mais mantêm) nenhuma relação de troca entre si.

Outra coisa: a morte, em suas duas vias, ou seja tanto do ponto de vista de quem a sofre quanto o de quem a comete, é tida como um ato de predação, mais 
precisamente, como uma devoração - como já vimos, em uma linguagem crua geralmente utilizada pelos envolvidos no conflito, diz-se que alguém foi devorado por seus inimigos.

Aproximamo-nos assim do debate sobre a guerra indígena, a vingança etc. Penso particularmente às intervenções de Carlos Fausto, que, partindo das reflexões de Pierre Clastres sobre o tema, aborda com razoável profundidade a guerra ameríndia em geral e a "guerra yanomami" em particular, tanto em seu artigo "Da inimizade. Forma e simbolismo da guerra indígena" quanto no sua obra Inimigos fiéis, e que trataremos mais adiante. Pois antes de avançar sobre essa discussão - tão importante para etnologia ameríndia -, é preciso reconhecer que já nos anos 1970, antecipando de algumas décadas uma visada que se tornaria dominante no americanismo, o próprio Clastres, refletindo sobre a guerra, afirmava que a lógica da sociedade indígena é uma lógica da diferença e não uma lógica da identificação:

"não se trata de psicologia primitiva, mas de lógica sociológica: há, imanente à sociedade primitiva, uma lógica centrífuga da atomização, da dispersão, da cisão, de modo que cada comunidade tem necessidade, para se pensar como tal (como totalidade uma), da figura oposta do estrangeiro ou do inimigo, e assim a possibilidade da violência está inscrita de antemão no ser social primitivo; a guerra é uma estrutura da sociedade primitiva e não o fracasso acidental de uma troca malsucedida" (Clastres 2004 [1977]:257).

É exatamente o que vínhamos dizendo mais acima a respeito dos Yanomami, bastando apenas substituir o termo morte por guerra. Mas, antes de mais nada, temos que reconhecer também que Clastres virara de cabeça para baixo 0 paradigma troca/reciprocidade - que até então dava conta de maneira unânime da sociabilidade primitiva -, colocando na pauta de reflexão etnológica a guerra e a violência entre os povos indígenas. Além disso, vale a pena lembrar que, no início dos anos 1970, o etnólogo francês visitara os Yanomami do Alto Orenoco em companhia de Jacques Lizot, experiência que marcou profundamente sua teoria da guerra indígena. A guerra primitiva é apenas outra maneira - e talvez não a mais inteiramente adequada - de se tratar a morte entre os ameríndios, o que veremos mais adiante. Assim mesmo, é para nós, inegável a pertinência da reflexão de 
Clastres sobre o tema. Carregamos também a impressão de que ela se tornaria muito mais fecunda se a morte tão prematura do etnólogo não a tivesse interrompido.

Comentando $A$ arqueologia da violência: a guerra nas sociedades primitivas, Bento Prado Jr, em seu prefácio à edição brasileira, sublinha que o que interessa nesse texto "é o modo pelo qual ele põe em xeque a transparência da troca e da comunicação como regra de constituição da sociedade" (in Clastres 2004 [1977]:9). Clastres considera primeiro que, independentemente de seu modo de produção, de seu sistema técnico-econômico, nenhuma sociedade primitiva "ignora ou recusa o desdobramento guerreiro de uma violência que envolve o ser mesmo de cada comunidade implicada no conflito armado", para em seguida concluir que "não se pode pensar a sociedade primitiva sem pensar também a guerra, a qual, como dado imediato da sociologia primitiva, adquire uma dimensão de universalidade" (Clastres 2004 [1977]:235).

Lamentando a ausência de uma reflexão sobre a guerra na etnologia de então, que, segundo o autor, aderira a um discurso sociológico tendendo a excluir a violência do campo das relações sociais, Clastres, no final de sua vida, foi ainda mais longe, afirmando que nenhuma teoria geral da sociedade primitiva poderia deixar de levar em conta o conflito:

"Não apenas o discurso sobre a guerra faz parte do discurso sobre a sociedade, como também Ihe dá sentido: a idéia da guerra serve de medida à idéia da sociedade" (Clastres 2004 [1977]:236)

Mais adiante, Clastres considera que o discurso então aceito sobre a guerra primitiva, heterogêneo, tomava três direções distintas: um naturalista, exemplificado pelas opiniões de Leroi-Gourhan; um discurso economista, fundado na certeza vaga do senso comum de que a vida primitiva era mergulhada na miséria e infelicidade; e, finalmente, o discurso sobre a guerra alusivo à troca, de autoria de Lévi-Strauss.

No que diz respeito à primeira dessas correntes, a naturalista, Clastres rebate os argumentos de Leroi-Gourhan, que reporta a violência à produção alimentar através da caça: 
"Em todo curso do tempo, a agressão aparece como uma técnica fundamentalmente ligada à aquisição e, no primitivo, seu ponto de partida está na caça, onde a agressão e a aquisição alimentar se confundem",

afirma Leroi-Gourhan (apud Clastres 2004 [1977]:237). Mas se Clastres talvez tenha razão em condenar essa identificação um tanto apressada da violência a uma necessidade biológica do homem enquanto ser vivo, a de caçar para comer, seria difícil a alguém familiarizado com a etnografia amazônica não vir imediatamente ao espírito essa unanimidade entre os povos ameríndios, que é exatamente a de assimilar a guerra à predação e à caça.

"A menos que se suponha o objetivo da guerra ser sempre alimentar e que o objeto desse tipo de agressão é o homem como animal de caça destinado a ser comido, essa redução da guerra à caça operada por Leroi-Gourhan não tem nenhum fundamento",

clama Clastres (2004 [1977]:239). É bem verdade que os conflitos indígenas não têm objetivo estritamente alimentar, mas o fundamento para as afirmações de LeroiGourhan, temos que reconhecer, talvez esteja na própria perspectiva nativa. Ora, no caso yanomami, por exemplo, a morte de um inimigo em combate é, justamente, tratada como uma devoração de uma maneira metafórica pelos agressores - no caso do homicida, ela é literalmente vivida como uma devoração. E essa é, ao nosso ver, uma das chaves para se entender a guerra ameríndia. É bem possível que Clastres (que era tanto um etnólogo de campo quanto teórico), se tivesse tido mais tempo, chegasse inevitavelmente a esta conclusão. Aliás, nos últimos anos de sua vida, juntamente com sua mulher Helène Clastres, tinha-se aproximado dos Yanomami, através de sua relação com Lizot...

Já a visão economista da guerra indígena, conforme Clastres, vai buscar suas razões em uma certeza vaga mas eficaz do senso comum, que se formou a partir do século XIX, a de que a vida primitiva seria marcada pela miséria e pela infelicidade o que foi acolhido, mais tarde, nas ciências humanas com o estatuto de discurso científico. No que diz respeito aos povos amazônicos, esta visão deve sua vitalidade a Julian Steward, responsável pelo Handbook of South American Indians e mentor da ecologia cultural (Clastres 2003 [1974]:16). Assim, a economia primitiva, marcada por um pobre desenvolvimento tecnológico e pela impotência diante da natureza, 
não conseguiria tirar essas sociedades da escassez e da miséria. O resultado dramático e inevitável desse "grau zero da economia" seria um quadro de guerra perpétuo, com os homens se disputando ferozmente os parcos recursos existentes, suficientes apenas para não deixá-los morrer de fome.

Como já bem sublinhou Fausto (1999), Clastres, apoiando-se nos argumentos que Sahlins apresenta em seu texto "A primeira sociedade da abundância", inverte o juízo da escassez primitiva, para o da afluência. Ora, afirma Clastres (2004: ),

"o Modo Produção Doméstico permite na realidade uma satisfação total das necessidades materiais da sociedade, ao preço de um tempo reduzido de atividade de produção e de uma baixa intensidade dessa atividade".

Lembrando ainda as pesquisas de Lizot a respeito da produção alimentar entre os yanomami da Venezuela, Clastres conclui que as sociedades primitivas, ao contrário de consumir-se tentando sobreviver, são, na verdade, verdadeiras sociedades de lazer. A escassez é, isto sim, produzida pela economia das sociedades modernas, na inadequação estrutural entre as necessidades forjadas e a riqueza efetivamente distribuída entre seus membros. Assim, para Clastres, fica claro que a associação entre guerra e escassez não passa de mais uma quimera a respeito das sociedades primitivas.

Finalmente, e é o que mais nos interessa, Clastres trata do discurso sobre a guerra relativo à troca, subjacente à obra de Lévi-Strauss: partindo de seu único texto a respeito, "Guerre et commerce chez les Indiens de l'Amérique du Sud", de 1943, Clastres concorda com Lévi-Strauss, para quem a guerra não pode ser pensada isoladamente, por si mesma, na medida em que não possui especifidade própria e só pode ser compreendida "vinculada à rede geral das relações que encerram os grupos", já que "a violência é apenas um caso particular desse sistema global", (Clastres 2004 [1977]:245). Em relação aos outros discursos, já é um enorme passo, que coloca a guerra no campo das relações sociais. Até aqui os dois etnólogos franceses estão de acordo. Mas só até aqui.

Clastres abrevia assim uma primeira visão de Lévi-Strauss a respeito: as relações entre as comunidades indígenas são, antes de mais nada, relações comerciais e de seu sucesso ou fracasso depende a paz e a guerra entre elas. 
"Qual é, para Lévi-Strauss, a relação entre guerra e sociedade? A resposta é clara: 'As trocas comerciais representam guerras potenciais pacificamente resolvidas, e as guerras são o resultado de transações mal-sucedidas."' (Clastres 2004 [1977]:246).

No entanto, Clastres constata que Lévi-Strauss, em Estruturas Elementares do Parentesco, não só distingue o comércio da troca, como também, muito apropriadamente, abole o primeiro de suas análises em favor das noções de troca e dádiva.

Não resta dúvida, segundo Clastres, de que o modo de produção doméstico, além de permitir uma vida de abundância, satisfazendo todas as necessidades humanas, tende fortemente a alimentar um ideal de autarquia, levando cada comunidade a produzir tudo o que necessita sem o auxílio de outrem.

"Ao decidir não depender senão de si mesma para sua produção de consumo, a comunidade primitiva exclui por isso mesmo a necessidade de relações econômicas com os grupos vizinhos",

argumenta nosso autor, acrescentando que esse ideal autárquico vai portanto de encontro aos princípios do comércio, o qual é ignorado pelo modo de produção doméstico, cujo funcionamento tende precisamente a excluí-lo de seu seio (2004 [1977]:247-48).

Assim, se não se trata mais de comércio - que afinal de contas inexiste entre os indígenas -, será a troca que irá explicar então a guerra para Lévi-Strauss, seguindo, porém, a mesma lógica negativa: bem como no caso do comércio, a guerra é um não-êxito eventual da troca, esta sim essência mesma da sociedade primitiva. Como salienta Clastres, a guerra, para Lévi-Strauss, é a própria negação dessa sociedade, na medida em que aquela é a não realização do ser social primitivo, que é um ser-para-a-troca (2004 [1977]:248).

O fenômeno da guerra se vê assim abolido da reflexão sobre as sociedades indígenas no pensamento de Lévi-Strauss. "Não por negligência ou ignorância", ressalva Clastres, "mas porque a consideração da guerra é incompatível com sua análise da sociedade, análise que só se sustenta excluindo a função sociológica da guerra na sociedade primitiva" (2004 [1977]:249). Todavia, ao contrário do que pensa Lévi-Strauss, a sociedade ameríndia não é o espaço exclusivo da troca, é 
também o da morte e da guerra. Apenas os dois fenômenos não estão no mesmo plano sociológico, no entender de Clastres, para quem o ponto de vista lévistraussiano é uma inversão simétrica do de Hobbes. Este não leva em conta a troca, aquele não considera a guerra.

Não se trata, evidentemente, de recusar a troca e a reciprocidade como princípio da socialidade indígena, mas sim de reconhecer que não é possível pensar as sociedades indígenas sem levar em conta a guerra: "a sociedade primitiva é o lugar do estado de guerra permanente" (2004 [1977]:260). Também não é o caso, adverte Clastres com razão, de justapor simplesmente os discursos a respeito da guerra e da troca. Para o nosso autor, Lévi-Strauss confunde dois níveis distintos do fenômeno troca: o primeiro, a troca como princípio transcendental, que instaura a socialidade humana, situado no mesmo nível que a proibição do incesto e que a exogamia; e outro, a troca como dado empírico, inserida nas relações políticas entre os grupos como meio de reforçar a aliança.

A troca neste último nível é justamente tributária da aliança, que a circunscreve e restringe. Neste plano, é a aliança que estabelece e permite a troca e não o contrário. A aliança, por sua vez, é um corolário da guerra: precisa-se de aliados para combater inimigos - sem estes últimos, aqueles não teriam tanta relevância. Pelo menos, no entender de Pierre Clastres. É bem verdade, porém, que sua reflexão vai muito mais longe do que isto e o mínimo que poderíamos fazer aqui é expô-la, mesmo que de uma maneira sucinta. A guerra, para ele, é um sistema e interrogar-se sobre ela é interrogar "o ser mesmo da sociedade [indígena]" (2004 [1977]:250).

A fragmentação da sociedade indígena sempre fora vista como a causa do estado perene de guerra entre essas populações. Para tanto, concorria também a eterna escassez de recursos, cuja concorrência acirrava ainda mais a animosidade entre os grupos. Para Clastres, contudo, se pretendemos entender a relação entre a multiplicidade das unidades sociopolíticas e a violência, devemos então inverter o sentido em que se apresenta: "não é a guerra que é o efeito da fragmentação, a fragmentação é que é o efeito da guerra". E mais: ela não é só o efeito, mas sobretudo a finalidade da guerra: 
"Em seu ser, a sociedade primitiva quer a dispersão. Esse querer da fragmentação pertence ao ser social primitivo que se institui como tal na e pela realização dessa vontade sociológica" (Clastres 2004 [1977]:250).

Acompanhemos então Clastres em sua reflexão. O plano efetivo de existência da sociedade indígena é a comunidade; ou, em outras palavras, o grupo local é sua unidade política. Ele reúne e integra os elementos que o compõem; tanto os que derivam dos laços de parentesco (famílias extensas, linhagens) quanto os de outra natureza, como classes de idade, sociedades de guerreiros etc., emergindo como unidade política inscrita em um território dado, do qual tem o controle e direitos de uso exclusivo. Esse grupo local - a unidade política da sociedade indígena apresenta duas propriedades fundamentais, que determinam seu ser social e também o princípio de inteligibilidade da guerra: a sociedade indígena "é ao mesmo tempo totalidade e unidade", afiança Clastres (2004 [1977]:254), explicando em seguida:

"Totalidade porque é conjunto acabado, autônomo, completo, atento em preservar a todo instante sua autonomia, sociedade no sentido pleno do termo. Unidade porque seu ser homogêneo persevera na recusa da divisão social, na exclusão de desigualdade, na interdição da alienação".

Trinta anos depois, é bem verdade, enxergando nela um viés monista, estamos mais à vontade para divergir desta visão das sociedades indígenas; mas ainda assim vale a pena retomar o que Clastres argumenta mais adiante:

"A sociedade primitiva é totalidade una porque o princípio de sua unidade não the é exterior: ela não deixa nenhuma figura do Um destacar-se do corpo social para representá-la, para encarná-la como unidade" (2004 [1977]:254).

Deste modo, para Clastres, ao mesmo tempo em que a comunidade afirma sua autonomia e alteridade diante de outras unidades semelhantes - autonomia fundada no princípio de autarquia econômica e soberania política -, ela também impede que qualquer forma de desigualdade surja diferenciando seus membros e inaugurando a divisão em seu interior.

Mesmo a figura do chefe, pondera nosso autor, não dispõe de poder efetivo e sua função é a de "falar em nome da sociedade", não exprimindo jamais seus 
desejos ou suas ordens pessoais. A alteridade é assim projetada para fora da comunidade:

"É diante das comunidades ou bandos vizinhos que tal comunidade ou tal bando determinado se afirma e pensa como diferença absoluta, liberdade irredutível, vontade de manter seu ser como totalidade una". E mais: "A comunidade primitiva pode se afirmar como totalidade porque se institui como unidade: ela é um todo finito porque é um nós indiviso". (Clastres 2004 [1977]:254-55).

Realmente, só teríamos a ganhar relativizando um pouco esse retrato da comunidade indígena. Tais (com)unidades não são tão indivisas assim, tanto é que não raro se cindem - o que sugere mesmo ser a regra -, e a rede de relações que tecem em âmbito regional nos mostra que elas estão, mais do que parece, abertas ao exterior. Mas não nos apressemos, pois é o próprio Clastres quem, logo em seguida, pondera seu ponto de vista. Apesar de se mostrar funcionando sem conflito e contradições e parecer girar em torno de sua própria reprodução, o sistema se movimenta e "a mônada primitiva, ao invés de permanecer fechada em si mesma, abre-se para as outras na intensidade extrema da violência guerreira" (Clastres 2004 [1977]:255). E aqui encontramos uma das brilhantes intuições de Clastres, quando remete esse impulso guerreiro à lógica da sociedade indígena, que, julga, é uma lógica da diferença, que para poder pensar-se necessita da figura do inimigo.

Retomemos então os passos de Fausto (1999), que parece prosseguir de maneira conseqüente a trilha da reflexão iniciada por Clastres, levando-a mais adiante. Fausto vê a guerra ameríndia sobretudo como um processo de consumo produtivo. Este conceito é uma das peças chave na sua teoria acerca da economia sócio-simbólica ameríndia. Para construí-la, o autor parte de duas premissas tidas como consenso bem estabelecido na etnografia sul-americana: a primeira delas dá conta de que os sistemas indígenas, por meio do investimento simbólico e ritual, estão orientados fundamentalmente para a produção de pessoas e grupos, e não de bens. Os ritos, as reclusões, os resguardos e o luto são assim exemplos de empreendimentos que visam produzir pessoas, conferir-lhes singularidade, atributos e capacidades: "Trata-se de economias que produzem pessoas e não objetos" (Fausto 1999:265-66). 
A segunda premissa concerne a percepção partilhada por grande parte das comologias sul-americanas segundo a qual identidade e interioridade são associadas à esterilidade e à imobilidade social. Ou seja, o entre-si, o nós - espaço marcado pela ausência de predação e terreno fértil aos atos de generosidade e solidariedade -, é, no entanto, caracterizado também pela incompletude, pois incapaz de reproduzir-se isoladamente. Entre si, os grupos produzem apenas corpos e não pessoas (1999:272). O que faz com que cada unidade social dependa da relação com o exterior para desenvolver-se. "Seja interna ou externa, a diferença é o fundamento do processo produtivo", argumenta Fausto, citando Joanna Overing:

"O modo de produção indígena requer 'a força e os poderes criativos daqueles difrentes do self, e sem o benefício de tal alteridade não pode haver fertilidade nem capacidade produtiva"' (Fausto 2001:537).

Existe, porém, mais de uma maneira de definir o externo e o interno e de estabelecer as relações entre os dois e, conseqüentemente também, as modalidades de relação com a alteridade constitutiva. Fausto sustenta que há dois esquemas básicos, não exclusivos e que até mesmo podem combinar-se, com ênfase em um ou outro aspecto, dando origem a duas formas sociais e cosmológicas distintas: trata-se da troca e da predação. Nas sociedades constituídas segundo o primeiro caso, onde a troca predomina sobre a predação, vemos uma maior abertura do sistema nos aspectos sociológicos e uma cosmologia mais fechada. Fausto avança como exemplo as formações multiétnicas do Alto Xingu e do Alto Rio Negro, onde a diferença interna entre os grupos dá conta do dinamismo e faz o sistema social funcionar, principalmente através das trocas rituais, materiais e matrimoniais entre si (Fausto 1999:66).

O segundo caso, onde a predação é o princípio constitutivo, encontramos uma maior homogeneidade interna e formações sociais atomizadas - que Fausto lembra ser o modelo tomado por Clastres em sua reflexão sobre a guerra. Se ambos os sistemas se prestam a produção social de pessoas como mecanismo de reprodução social, suas formas de atingir tal objetivo, porém, são distintas: no primeiro sistema a pessoa ideal é formada pela aquisição de atributos sociais significativos (nomes, cantos etc.), que confirmam e instituem a alteridade no interior 
do próprio sistema. Já no segundo caso, "a pessoa ideal é constituida pela aquisição violenta de potência no exterior da sociedade (na forma de nomes, cantos e almas de inimigos)" (Fausto 1999:266). O autor cita as sociedades yanomami, jivaro e tupinambá, como exemplos de onde poderia ser observado este tipo de formação e presta ainda um tributo à Clastres:

"Nesse sentido, pode-se dizer com Clastres que a "guerra" é uma
estrutura das sociedades ameríndias: uma forma privilegiada de
relação com o exterior fundada em certas representações,
disposições, formas institucionais e práticas sociais" (Fausto
1999:266).

Fausto recusa-se a tratar essa apropriação violenta no exterior para a produção de pessoas no interior como uma simples expressão do princípio da troca, da reciprocidade. De fato seria muito cômodo - e ao que parece também muito infrutífero - descrever a guerra ameríndia como uma modalidade da troca: de mortos, de violência... E é, segundo Fausto, o que faz precisamente Lizot ao tratar do caso yanomami:

"A troca e a reciprocidade, sob formas múltiplas, em diferentes níveis, constituem 0 tecido das relações sociais e políticas yanomami, e um feixe de índices convergentes parece indicar que a reciprocidade equilibrada que funda as relações pacíficas, e a violência e a guerra, constitui duas modalidades complementares, mas inseparáveis, da troca tomada no sentido mais geral" (apud Fausto 1999:262)

Então, segundo o autor, mesmo se admitimos que a guerra tal como a troca fazem parte de um sistema maior de comunicação que instaura as redes sociais, não significa que devemos identificar a primeira à segunda e tomar a troca como modelo explicativo para a guerra e os conflitos:

"A passagem sem mediações da guerra à troca tende a esvaziar a dimensão política da guerra, a obscurecer sua fenomenologia e a anular o campo do sujeito" (Fausto 1999:263).

Fausto propõe então que pensemos a guerra fazendo sim parte de um sistema, mas desta vez trata-se de um sistema em que os excedentes são tanto materiais quanto simbólicos e volta-se fundamentalmente para a produção de corpos pessoas (1999:265). 
Para tanto, propõe então o conceito de consumo produtivo, o qual, segundo ele, torna mais evidente tanto tratar-se de um caso de consumo, gasto e não de transferência e simples circulação, quanto a negatividade da guerra. Além do mais, o conceito se aproxima do ponto de vista ameríndio, que, este, trata a guerra e a morte como predação, manducação. Enfim, a idéia de consumo produtivo tem seu aspecto positivo:

"o consumo não é apenas perda, mas gasto produtivo. A morte do inimigo alhures produz em casa corpos, nomes, identidades, novas possibilidades de existência; enfim, a morte do outro fertiliza a vida do mesmo, ela é life-giving" (Fausto 1999:267).

E como o conceito de consumo produtivo desdobra-se no de predação familiarizante? Ao liquidar um inimigo, o matador não produz simplesmente seu desaparecimento, mas estabelece um novo tipo de relação com sua vítima e, ao término de um processo que é marcado pelos ritos do homicida ou de resguado, torna-se um outro homem, mais forte, mais criativo e também mais perigoso, pois contendo em si uma nova subjetividade, a que tomou de sua vítima para si. O homicídio é entendido de certa forma como uma devoração ontológica. Na verdade, o matador captura o espírito, sopro ou princípio vital do morto, estabelecendo uma relação de domesticação com sua vítima - que tem nos laços ligando o dono ao xerimbabo seu modelo. Ou seja, a relação de hostilidade converte-se em relação de controle, de domesticação, do gênero daquela que o xamã estabelece com seus espíritos auxiliares: "o matador passa a controlar simbolicamente sua vítima com se ela fosse seu animal de estimação" (Fausto 1999:268), daí a predação familiarizante.

Este modelo dá conta, é verdade, dos exemplos etnográficos avançados pelo autor. É o caso, por exemplo, dos Araweté, grupo tupi-guarani do vale do Xingu, Pará, onde o homicida captura o espírito de sua vítima, domesticando-o durante o resguardo ${ }^{87}$. Tal acontece de certa forma também com os Parakanã, que, apesar de

\footnotetext{
${ }^{87}$ É bem verdade que o inimigo morto também inspira ao matador Araweté os cantos awi marakã. Mas para eles, a morte infligida vale sobretudo uma morte sofrida: "o matador torna-se um deus 'sem passar pela prova" da devoração" [por parte do deuses Mái]. Ou mesmo sem passar pela prova doa
} 
não se apropriarem do espírito da vítima, quando a matam, são contaminados pelo seu cheiro de sangue e sua "gordura-mágica", o que Ihes permite sonhar, além de os tornarem mais violentos. Ora, é através do sonho que os Parakanã irão domesiticar inimigos, humanos ou não, tornando-os seus xerimbabos. Esses inimigos domesticados lhes darão cantos xamânicos e nomes que portarão suas crianças.

As reflexões de Fausto sobre a guerra, embora certamente pertinentes e se enquadram dentro da tendência e das preocupações contemporâneas da etnologia das terras baixas sul-americanas. Temo, no entanto, que não sejam tão produtivas no nosso caso, o yanomami, onde a utilização de tal modelo nos leva senão ao impasse ao menos não nos faz avançar muito. A primeira dificuldade seria menos estabelecer a fronteira entre o interior e o exterior do que dosar em que medida os esquemas de troca e predação se conjugam para conformar o sistema.

Se por um lado, temos todos os ingredientes clássicos da predação amazônica, a morte do inimigo sendo efetivamente tomada como um ato de predação - mais ainda, de manducação; sendo o rito de reclusão do homicida e todas as retrições impostas ao matador encarados como um processo de digestão de sua vítima -, por outro, falta-nos a apropriação por parte do homicida de qualquer elemento constituinte da vítima: nem alma, nem princípio vital, nem nomes, nem cantos...

Estamos bem longe de um sistema como o Jivaro, por exemplo. Para estes, a tsantsa, a cabeça reduzida do inimigo, encerra um jogo de relações complexo, remetendo a uma procriação simbólica; assim, ao término deste, o troféu torna-se o princípio de uma nova vida, assumindo o papel do embrião, de uma criança que deverá nascer no seio da parentela do matador. Enfim, dá lugar ao que Descola afirma ser o fruto de uma afinidade sem afim, "a única satisfatória para os Jivaro, visto que desembaraçada de toda obrigação de reciprocidade" (Descola 1993:183).

Não vislumbramos também nenhum modelo fundado na circulação de energia ou de forças geradoras de vida - as trocas com o exterior visando a compensar

morte tout court - de alguns famosos guerreiros da antiguidade, dizem os Araweté que não morreram, mas subiram aos céus em corpo e alma (Viveiros de Castro 1984:63). 
perdas através de injeção de forças ou de energias equivalentes para manter um estoque inicial limitado -, como, seria o caso, por exemplo, dos Yagua, dos Desana do Alto Rio Negro, ou ainda o dos Mundurucu, segundo Chaumeil (1983:126). Nesses sistemas, torna-se imperativo captar uma parcela desta energia e isto é feito através do xamanismo, da caça ou da guerra, visto que uma perda de energia não compensada é vista como uma queda do potencial energético do grupo (id. ibid.).

Apesar de o termo que designa a vingança - no yuai, ou no yuo -, poder ser traduzido como tomar ou estar na posição de alguém que vai se apoderar de alguma coisa - o verbo yuai sem o prefixo no quer dizer justamente tomar, se apoderar de algo -, é difícil dizer o que realmente é tomado do morto. Além disso, podemos também entender no yuo, a forma intransitiva do verbo, como se pegar, ou seja, pelejar.

Além da própria vida, creio que do morto yanomami, o matador não se apodera de nada. Talvez estejamos simplesmente procurando no lugar errado. A meu ver, é a própria morte que, instaurando a alteridade nas margens da rede de relações, garante o dinamismo do sistema, na medida em que ratifica o ideal da comunidade como reduto da identidade e em irremediável oposição ao exterior efetivamente ou potencialmente hostil. Ideal, aliás, afiançado de todas as maneiras pelo xamanismo, cuja prática é, acima de tudo, ideologicamente centrada na comunidade. Como vimos até aqui, o ritual funerário refaz o grupo a cada episódio de morte entre os seus.

E é sugestivo, nesse sentido, o nome dado pelos Sanumá ao rito: xaponomou (cf. Taylor 1996). Ora, xapono é o nome dado à casa-aldeia; o verbo xaponomou pode ser traduzido por "construir uma casa coletiva" e é empregado justamente neste caso. Assim, quando os Sanumá referem-se ao funeral como construção da casa comunal, é como se me dessem razão quando afirmo que é o reahu que faz comunidades...

No caso yanomami, a morte se encontra submetida à lógica da vingança e de certo modo se auto-replica indefinidamente. Na maior parte dos casos, um ciclo de morte - vingança - revide - nova morte - nova vingança... instaura-se e o grupo vive um longo período em uma espécie de "fuite en avant", até que o lado mais fraco 
acaba entendendo que fugir da cena do conflito e buscar refúgio na distância - onde isto ainda é possível - é o melhor a fazer. Mas, até então, tudo se passa como se a vida quotidiana fosse suspensa: o trabalho na roça é reduzido ao mínimo por motivos de segurança; as andanças coletivas pela floresta - em que se coletam os frutos silvestres da estação - são abandonadas e as atividades de cada um passam a ser condicionadas em função da possibilidade sempre presente de ser alvo de uma emboscada. Enfim, as atividades de subsistências são limitadas ao mínimo necessário - a tal ponto que fazer a guerra a um grupo pode ser expresso também pelo verbo ohëmai, ou seja, causar-Ihe fome.

Poderíamos nos perguntar então por que os grupos enveredam por tal caminho, se não prefeririam evitar tal situação - mesmo depois de sofrer um ataque inimigo. Ao colocar-Ihes a questão, diante de um enfrentamento, de um duelo, escutei por diversas vezes os Yanomami afirmarem o seguinte:

"Parimi ya kuo kunoha, ya xĩro kiri; parimi yaimi ha, ya kirimi..."

"Se eu fosse eterno, teria medo [do combate]; não o sendo, não tenho medo!".

Sabia que se tratava de uma proposição que explicitava não só a posição yanomami face à guerra, mas também diante da própria morte.

Só que a achava incongruente, mesmo contraditória. "Se fosse eterno..." Ora, se fôssemos eternos, o que teríamos a temer? Não o sendo é que deveríamos fugir do risco, não? A confusão, com certeza, era minha e não do dito yanomami. Mas isto, só fui compreender muito mais tarde. Até então, o impasse se tornava mais enviezado para mim, na medida em que era também incitado a repetir o dito diante de meus desafetos e possíveis inimigos - yanomami e não-yanomami.

Cheguei mesmo a repeti-lo entre os Yanomami, causando até boa impressão. No entanto, sempre sem compreender de fato o princípio desta justificativa diante do risco, ou da própria morte...

O impasse só foi superado com a ajuda de Vernant e seu texto $A$ morte heróica entre os gregos (2001) e através das palavras do grego Sarpedon. Vernant conta que, durante a guerra de Tróia, Aquiles se retirando da luta, a situação tornouse insustentável para os gregos; os troianos os obrigando a abandonar o cerco à 
cidade e a se refugiarem em seus navios. Dois Lyciens, Glaucos e Sarpedon, descritos como personagens heróicos, "jeunes gaillards", ávidos para se lançarem à luta "au premier rang", discutem o que motiva os valentes a fazerem tanto. O próprio Sarpedon argumenta que na medida em que recebem tantas honras, bens e belas mulheres, devem fazer então jus a isto, não hesitando a se lançar no furor da batalha na linha de frente... Enfim, já que são ou vivem como reis, devem portanto fazê-lo...

Ora, são falsos argumentos, como nos lembra Vernant. Agamenon é rei e não o faz; ao contrário de Aquiles que não o sendo, o faz sem hesitar. Na verdade, em sua desavença com Agamenon, Aquiles o afirmou mesmo com todas as palavras, humilhando seu próprio rei:

"De qual direito me a tomaste [a bela Briséis, butim de guerra de Aquiles, tomado indevidamente por Agamenon]? Tu não passas de um covarde. Tu te refugias nas últimas linhas, tu não sabes o que é, no corpo-a-corpo, o face-à-face contra o inimigo, de engajar sua psukhè..." (Vernant 2001:14-15), brava o héroi.

Então, não é essa a equação: realeza = valentia.

E é o próprio Sarpedon que recoloca as coisas em seu devido lugar:

"Se nós pudéssemos viver, nós pobres humanos, mortais e efêmeros, como os deuses, eternamente, sem conhecer a morte, e sempre jovens, sempre a perna e o braço em forma, então, eu não deveria te incitar a arriscar tua vida nas primeiras linhas. Mas nós assim não somos! À velhice, à idade avançada, à fatiga, à morte no fim da linha nós não escaparemos! Esta é a verdadeira razão pela qual eu te digo de ir" (2001: 23)

Tudo é dito... Agora, tudo está claro. É a mesma posição diante da morte que encontramos entre os Yanomami. Não que a morte não seja algo sempre e acima de tudo lamentável - acho, aliás, que esta é uma boa definição para o entendimento yanomami da morte: algo sobretudo lamentável; a lamentação, as lágrimas, são o que mais caracteriza a morte e marca definitivamente o luto. $O$ que nos dizem aí os gregos, como me disseram tantas vezes os Yanomami, é, afinal, que só estamos vivos porque somos mortais. Ou seja, só há vida porque há morte. E por isso só os vivos se lançam à guerra e à morte... não temem... 
Não ouvi de nenhum yanomami afirmação tão clara quanto a de Hapóro, de que "estar vivo é bom". Só posso dizer que, olhando para trás, para esta década que passei junto aos Yanomami, trabalhando e pesquisando, o balanço que faço é que foi muito bom estar vivo na companhia deles. Apesar da distância que sempre houve entre nós, a solidariedade, a simpatia e a alegria que demonstraram em nosso relacionamento me marcaram profundamente. Acho que nunca conseguirei quitar a enorme dívida afetiva e intelectual que contraí com eles. 


\title{
Bibliografia
}

\author{
ALBERT, Bruce
}

1985 Temps du sang, temps des cendres. Représentation de la maladie, système rituel et espace politique chez les Yanomami du sud-est (Amazonie brésilienne), tese apresentada em vista da obtenção do grau de doutor da Universidade de Paris, X, Paris

1992 "A fumaça do metal: história e representações do contato entre os Yanomami", in Anuário Antropológico, LxxxxIX, Rio de Janeiro, pp. 151-189

1995 "O ouro canibal e a queda do céu: uma crítica xamânica da economia política da natureza", Departamento de AntropologiaUnB, Brasília

\section{ALBERT, Bruce \& GOMEZ, Gale G.}

1997

Saúde Yanomami. Um manual etnolingüístico, Belém: PR/MCT/CNPq/Museu Paraense Emílio Goeldi, Coleção Eduardo Galvão

\section{ARIÈS, Philippe}

1975

L'histoire de la mort en Occident, Éditions du Seuil, Paris

1996

Le temps de gisants. L'homme devant la mort,tome I, Points, Paris

1996

La mort ensauvagée. L'homme devant la mort, tome II, Points, Paris

\section{BARANDIARÁN, Daniel de}

"Vida y muerte entre los indios sanema-yanoama" in Antropologica, no 21, dezembro de 1967, Caracas:Instituto Caribe de Antropologia y Sociologia 


\section{BEILLEVAIRE, Patrick \& BENSA, Alban}

1984

"Mauss dans la tradition durkheimieenne. De l'individu à la personne" in Critique, tome XL, Paris

\section{BENVENISTE, Émile}

1966 Problèmes de linguistique générale I. Paris:Gallimard

1974 Problèmes de linguistique générale II. Paris:Gallimard

\section{BIOCCA, Ettore}

1968

Yanoama. Récit d'une femme brésilienne enlevée par les Indiens, Paris:Plon

BORGES, Maria Inês

1999

O corpo cósmico: o xamanismo entre os yanomae do Alto Toototobi, tese de doutorado, Universidade de Brasília

\section{BRUMANA, Fernando Giobellina}

1983

Antropologia dos sentidos. Introdução às Idéias de Marcel Mauss. São Paulo: Brasiliense

\section{CCPY}

1997 Yamaki hwërimamouwi thë ã oni - Palavras escritas para nos curar, São Paulo

\section{CASTRO DE ANDRADE, Anna Maria de}

1997

Concepções e práticas na relação com o animal: reflexões sobre o caso yanomami, dissertação de mestrado, FFLCH-USP

\section{CARNEIRO DA CUNHA, Manuela}

1978

Os mortos e os outros. Uma análise do sistema funerário e da noção de pessoa entre os índios Krahó. São Paulo:Hucitec

"Eschatology among the Krahó: reflection upon society, free field of fabulation", in S. Humphreys \& King (eds), Mortality and 
Imortality (the antropology and archaeology of death), New York: Academic Press

\section{CHAGNON, Napoleon}

1966

Yanomamö warfare, social organization and marriage alliances. Tese de doutorado, Universidade de Michigan

1967 "Yanomamö social organization and warfare" in War: The Anthropology of Armed Conflict and Aggression, M. Fried, M. Harris \& R. Murphy (eds.), Garden City:Natural History Press, pp. 109-59

1997 [1968] Yanomamö. Holt, Rinehart and Winston, The Dryden Presse, Saunders College Publishing

\section{CHAGNON, Napoleon \& BUGOS Paul}

1979 "Kin selection and conflict: An analysis of a Yanomamo ax fight" in Evolutionary Biology and Human Social Behavior: An Anthropological Perspective, N. Chagnon \& W. Irons (eds.), North Scituate:Duxbury Press

\section{CHAGNON, Napoleon \& HAMES Raymond}

1979

"Protein deficiency and tribal warfare in Amazonia: New data" in Science Magazine, 203, American Association for Advancement of Science, pp. 910-13

\section{CHAUMEIL, Jean-Pierre}

1985 "Échange d'énergie: guerre, identité et reproduction sociale chez les Yagua de l'Amazonie péruvienne". Journal de la société des américanistes 71, pp. 143-157

1993

"L'autre sauvage. Chamanisme et alterité" in Amériques Latines: une altérité, C. Desemps (dir.), Paris:Centre Pompidou

\section{CLASTRES, Pierre}


1972 Chronique des Indiens Guayaki. Ce que savent les Aché, chasseurs nomades du Paraguay. Paris:Plon,

2004 Arqueologia da violência. Pesquisas de Antropologia Política. São Paulo:Cosac\&Naify

\section{CLASTRES, Hélène \& LIZOT, Jacques}

1978 "La muerte y la idea del canibalismo entre los yanomami" in Bol. Indigenista Venezolano, Tomo XVIII, No 14, Caracas, pp. 107142

\section{COLCHESTER, Marcus}

1985 "The Health and Survival of the Venezuelan Yanoama », Marcus Colchester, éd., ARC/SI/IWGIA Document 53, pp. 1-30

\section{COURSE, Magnus}

2007

"Death, Biography, and the Mapuche Person". Ethnos 72:I, pp. 77-101

\section{CRÉPEAU, Robert R.}

1993 "Mobilité économique et sédentarité en Amazonie". Recherches amérindiennes au Québec, 23-4, pp. 67-76

\section{DESCOLA, Philippe}

1993

"Les affinités sélectives. Alliance, guerre et prédation dans l'ensemble Jivaro". L'Homme, abril-dezembro 1993, XXXIII (2-4), pp. 171-190

1996 "Constructing natures. Symbolic ecology and social practice". In P. Descola \& G. Pálson (orgs.) Nature and Society. Anthropological Perspectives, London-New York:Routledge, pp. 82-102 


\section{DO PATEO, Rogério Duarte}

2005 "Guerra e devoração", in Gallois 2005 (org.), pp. 113-150

2005a "Niyayu. Relações de Antagonismo e Aliança entre os Yanomam da Serra das Surucucus (RR)". Tese de doutorado. FFLCH-USP, ms.

\section{DUMONT, Louis}

1992 [1966] Homo hierarchicus: o sistema de castas e suas implicações. São Paulo:EDUSP

\section{EVANS-PRITCHARD, Edward E.}

1977 [1940] The Nuer. A description of the modes of livelihood and political intitutions of a Nilotic people. New York-Oxford:Oxford University Press

\section{FAUSTO, Carlos}

1999

"Da inimizade. Forma e Simbolismo da guerra indígena" in Adauto Novaes (org.), A outra margem do Ocidente, São Paulo:Companhia das Letras,

2001 Inimigos Fiéis. História, Guerra e Xamanismo na Amazônia. São Paulo:EDUSP

\section{FERGUSON, R. Brian}

1995 Yanomami Warfare. Santa Fe:School of American Research Press

\section{FERREIRA GUIMARÃES, Sílvia Maria}

2005

"Cosmologia Sanumá: o xamã e a constituição do ser". Tese de doutorado, UnB

\section{FOX, Robin}


Anthropologie de la parenté. Une analyse de la consanguinité et de l'alliance, Paris:Gallimard

\section{GALLOIS, Dominique Tilkin}

1988 "O movimento na cosmologia wayãpi: criação, expansão e transformação do universo". Tese de doutorado, FFLCH-USP

\section{GALLOIS, Dominique Tilkin (org.)}

2005

Redes de relações nas Guianas. São Paulo:Associação Editorial Humanitas/FAPESP

\section{GEFFRAY, Christian}

1995 Chroniques de la servitude en Amazonie brésilienne. Paris:Karthala

\section{GHEERBRANT, Alain}

1993 [1952] Orénoque-Amazone. 1948-1950. Paris:Gallimard

\section{GOLDMAN, Márcio}

1996

"Uma categoria do pensamento antropológico: a noção de pessoa" in Revista de Antropologia, Paula Montero (ed.), Departamento de Antropologia, FFLCH-USP, São Paulo

GOODY, Jack

1996 L'homme, l'écriture et la mort. Entretiens avec Pierre-Emmanuel Dauzat, Les belles lettres, Paris

\section{HERTZ, R.}

1928 "Contribution à une étude sur la représentation collective de la mort" in Mélanges de sociologie religieuse et de folklore, Alcan, Paris

HOWARD, Catherine

1993

"Pawana: a farsa dos "visitantes" entre os Waiwai da Amazônia setentrional" in Amazônia. Etnologia e história indígena, E. 
Viveiros de Castro \& M. Carneiro da Cunha (orgs.), São Paulo:NHII-USP/Fapesp

\section{KELLY LUCIANI, José Antonio}

2001

"Fractalidade e troca de perspectivas" in Mana, vol. 7, no 2, Rio de Janeiro, disponível na internet através do site http://www.scielo.br

2003

"Relations within the Health System among the Yanomami in the Upper Orinoco, Venezuela". Tese de doutorado, Department of Social Anthropology and Darwin College. University of Cambridge

\section{KOCH-GRÜNBERG, Theodor}

1966 [1924] Del Roraima al Orinoco, tomo iii. Caracas:Edições du Banco Central de Venezuela

\section{KOPENAWA YANOMAMI, Davi}

1998

"Sonhos das origens", in http://www.socioambiental.org/pib/epi/

yanomami/desenv.shtm

\section{LATOUR, Bruno}

1994 Jamais fomos modernos. Ensaio de Antropologia simétrica, Rio de Janeiro:Editora 34

2004 "Le rappel de la modernité - approches anthropologiques". Conférence au séminaire de Philippe Descola, Collège de France, 26/11/2003, revisado para publicação em 04/2004, disponível na Internet no Site Latour

\section{LÉVI-STRAUSS, Claude}

1955

Tristes Tropiques. Paris:Plon

1972 [1964] Le Cru et le cuit. Paris:Plon

1982 [1966] Du miel aux cendres. Paris:Plon 
1988 [1968] L'origine des manières de table. Paris:Plon

1996 [1971] L'homme nu. Paris:Plon

\section{LIMA, Tânia Stolze}

1996

"O Dois e seu Múltiplo: Reflexões sobre o Perspectivismo em uma Cosmologia Tupi". Mana. 2(2), pp. 21-47

1999 "Towards an ethnographic theory of the distinction between nature and culture in the cosmology of the Juruna tribe" in Revista Brasileira de Ciências Sociais, São Paulo, v. 14, no 40

2005 Um peixe olhou para mim, o povo Yudjá e a perspectiva. São Paulo:UNESP/ISA, Rio de Janeiro:NuTI

\section{LIZOT, Jacques}

1973 "Onomastique yanomami". L'homme XIII (3), pp. 60-71 (republicado em Lizot 1984, cap. 7)

1976 Le cercle des feux. Faits et dits des Indiens yanomami. Paris:Seuil

1984 Les yanomami centraux. Cahiers de l'homme, N.s. no XXII, Paris:EHESS

1989 No Patapi tëhë. En los tiempos de los antepasados. Vicariato Apostólico de Puerto Ayacucho

1996 "Sang et Statut des homicides chez les Yanomami Centraux" in Destin des meurtriers. Systèmes de pensée en Afrique noire, 14, Paris:EPHE/CNRS

S/D Dictionnaire encyclopédique de la langue yanomami, em colaboração com Hepëwë, Nõhõkuwë e Tiyetirawë, (prelo)

\section{MALINOWSKI, Bronislaw}

[1921]1961 Argonauts of the Western Pacific. New York:Dutton 
MAUSS, Marcel

1993 [1924]

"Essai sur le don. Forme et raison de l'échange dans les sociétés archaïques", Sociologie et anthropologie, Paris:PUF, pp. 143-279

1993 [1938]

"Une catégorie de l'esprit humain: la notion de personne, celle de $\square$ moi $\square "$, Sociologie et anthropologie, Paris:PUF, pp. 331-362

MILLIKEN, William \& ALBERT, Bruce.

1999

Yanomami. A Forest People. Kew:Royal Botanic Gardens

OVERING, Joanna

1976 "Orientation for paper topics" in Actes du XLIle Congrès International des Américanistes, vol. II, Paris

PELLEGRINI, Marcos A.

1993

Wadubari. São Paulo:Marco Zero

\section{PERRONE-MOISÉS, Beatriz}

2008

"L'alliance normando-tupi au XVle. siècle: la célébration de Rouen". In Journal de la Société des Américanistes, 94-1, pp. 45-64.

PERRONE-MOISÉS, Beatriz (org.)

2006 "Redes ameríndias: geração e transformação de relações nas Terras Baixas sul-americanas", projeto de Pesquisa Temática, NHII-USP, FAPESP (Proc. 05/57134-2)

\section{RADCLIFFE-BROWN, Alfred Reginald}


1974 [1950] "Introdução", A.R. Radcliffe-Brown \& D. Forde (orgs.) Sistemas [políticos] africanos de parentesco e casamento, Lisboa:Calouste Gulbenkian, pp. 9-114

\section{RAMIREZ, Henri}

1992 Iniciação à língua yanomami, Diocese de São Gabriel da Cachoeira, São Gabriel da Cachoeira

1993 Hapa të pë rë kuonowei - Mitologia yanomami, Inspetoria Salesiana Missionária da Amazônia, Manaus

1994 Le parler yanomami des Xamatauteri, tese de doutorado, Universidade d'Aix-en-Provence

\section{RAMOS, Alcida}

1990

Memórias sanumá. Espaço e tempo em uma sociedade yanomami. Brasília/São Paulo: Marco Zero/EDUSP

\section{RIVIÈRE, Peter}

2001 [1984] O indivíduo e a sociedade na Guiana. São Paulo:EDUSP

\section{SEEGER, Antony, DA MATTA, Roberto \& VIVEIROS DE CASTRO, Eduardo B.}

"A construção da pessoa nas sociedades indígenas brasileiras" in Boletim do Museu Nacional, Nova Série Antropológica, $\mathrm{n}^{\circ} 32$, maio 1979, Rio de Janeiro

\section{SHAPIRO, Judith Rae}

1972

Sex roles and social structure among the Yanomama Indians of Northern Brazil, tese apresentada em vista da obtenção do grau de doutor da Universidade de Colúmbia

\section{STRATHERN, Marilyn}

1988

The gender of the gift. Berkeley: University of California Press

\section{SZTUTMAN, Renato}


2002 "Do dois ao múltiplo na terra do Um: a experiência antropológica de David Maybury-Lewis". Revista de Antropologia, vol. 45 no2, Departamento de Antropologia, FFLCH-USP, pp. 444-75

2005 "Sobre a ação xamânica". In Gallois (org.) 2005, pp. 151-226

TAYLOR, Kenneth I.

1996 "A Geografia dos Espíritos: o xamanismo entre os Yanomami setentrionais". In Jean M. Langdon (org.) Xamanismo no Brasil. Novas Perspectivas, Florianópolis:UFSC

\section{VERNANT, Jean-Pierre}

1994 L'individu, la mort, l'amour. Soi-même et l'autre en Grèce ancienne. Paris:Galimard, 1996,

\section{VILAÇA, Aparecida}

1992 Comendo como gente: formas de canibalismo wari. Rio de Janeiro:UFRJ

\section{VIVEIROS DE CASTRO, Eduardo B.}

1986

1993

1995

1996

1998

Araweté, os deuses canibais. Rio de Janeiro:Jorge Zahar/ANPOCS

"Alguns aspectos da afinidade no dravidianato amazônico". In E. Viveiros de Castro \& M. Carneiro da Cunha (orgs.) Amazônia: etnologia e história indígena, São Paulo:NHII-USP/FAPESP, pp. 149-210

"Pensando o parentesco ameríndio". In E. Viveiros de Castro, (org) Antropologia do parentesco. Estudos ameríndios, Rio de Janeiro:UFRJ

"Os pronomes cosmológicos e o perspectivismo ameríndio". Mana, 2(2), pp. 115-144

"Cosmological deixis and Amerindian perspectivism". Journal of the Royal Anthropological Institute, 4, 469-488. 
2001 "A propriedade do conceito" in "Uma notável reviravolta: antropologia (brasileira) e filosofia (indígena)", ANPOCS, ms.

$2002 \quad$ A inconstância da alma selvagem - e outros ensaios de antropologia, São Paulo:Cosac \& Naify

2004 The forest of mirrors. A few notes on the ontology of amazonian spirits, ms.

\section{VIVEIROS DE CASTRO, Eduardo B. \& BENZAQUEN, Ricardo de Araújo}

1977 "Romeu e Julieta e a origem do Estado" in Gilberto Velho (org.), Arte e sociedade. Ensaios de sociologia da arte, Rio de Janeiro:Zahar

\section{WAGNER, Roy}

1974

"Are there social groups in the New Guinea Highlands?" in Leaf, M.J. (org.) Frontiers of anthropology:an introduction to anthropological thinking. New York :D. Van Nostrand Co., pp. 95-122

\section{WILBERT, J. \& SIMONEAU, K. (orgs.)}

Folk literature of the Yanomami indians. UCLA Latin American Studies, 73, University of California (Los Angeles) 